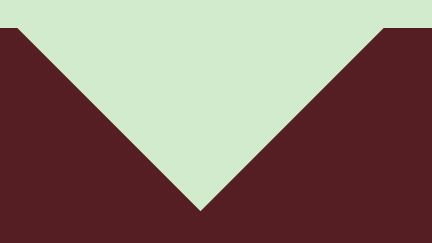

ECKART SCHÜTRUMPF

\title{
THE EARLIEST TRANSLATIONS
}

\section{OF ARISTOTLE'S POLITICS}

AND THE CREATION OF POLITICAL TERMINOLOGY 



\section{MORPHOMATA \\ LECTURES COLOGNE}

8

HERAUSGEGEBEN VON GÜNTER BLAMBERGER

UND DIETRICH BOSCHUNG

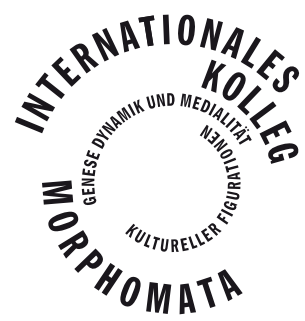





\section{THE EARLIEST TRANSLATIONS} OF ARISTOTLE'S POLITICS

AND THE CREATION OF POLITICAL TERM IN OLOGY

WILHELM FINK 
GEFÖRDERT VOM

Bundesministerium

für Bildung

und Forschung

unter dem Förderkennzeichen 01UK0905. Die Verantwortung für den Inhalt der Veröffentlichung liegt bei den Autoren.

Bibliografische Informationen der Deutschen Nationalbibliothek: Die Deutsche Nationalbibliothek verzeichnet diese Publikation in der Deutschen Nationalbibliografie; detaillierte Daten sind im Internet über www.dnb.d-nb.de abrufbar.

Alle Rechte, auch die des auszugweisen Nachdrucks, der fotomechanischen Wiedergabe und der Übersetzung vorbehalten. Dies betrifft auch die Vervielfältigung und Übertragung einzelner Textabschnitte, Zeichnungen oder Bilder durch alle Verfahren wie Speicherung und Übertragung auf Papier, Transparente, Filme, Bänder, Platten und andere Medien, soweit es nicht $₫ 53$ und 54 UrhG ausdrücklich gestatten.

(C) 2014 Wilhelm Fink, Paderborn

Wilhelm Fink GmbH \& Co. Verlags-KG, Jühenplatz 1, D-33098 Paderborn

Internet: www.fink.de

Lektorat: Sidonie Kellerer, Thierry Greub

Gestaltung und Satz: Kathrin Roussel, Sichtvermerk

Printed in Germany

Herstellung: Ferdinand Schöningh GmbH \& Co. KG, Paderborn 
CONTENT

1. The earliest Latin translations of AristotleWilliam of Moerbeke

2. Nicole Oresme

3. Leonardo Bruni's principles of translation

4. Bruni's translation of Aristotle's Politics

5. The political terminology in Bruni's translationa new Humanist concept of res publica?

6. The controversy over Bruni's translationcontemporary and modern

Appendix

Bibliography 

This study goes back ultimately to a response I gave on two papers presented on "Translating Aristotle's Politics in Medieval and Renaissance Europe" at the "International Conference on Translation. The History of Political Thought," at CUNY in 2005. Immersing myself in the more recent scholarly literature on Humanist translations of Greek philosophical texts I learned that one voice was all but absent-the voice of classicists whose scholarly focus is the Greek texts that were translated from the $13^{\text {th }}$ century onwards. Such a voice needs to be heard especially for an assessment of the style of the Greek originals and for the ancient tradition behind the emerging political terminology in the 14th century, e.g. the changing meaning of res publica. For both issues an informed reference to classical texts will at times lead to different results than those drawn by Medievalists. This study examines the earliest Latin translations of Aristotle's Politics from the angle of a classicist.

I presented arguments of this study at the Humboldt University Berlin, University of Cologne, University of Colorado at Boulder, Universidad Carlos Terzero Madrid, and the Ludwig Maximilian University of Munich. I am grateful for the critical comments I received. My former student Dr. S. Farrington and my daughter Caroline Schütrumpf checked the English of this text; any remaining flaws are my responsibility. I would like to thank the directors of the Morphomata Center for Advanced Studies at the University of Cologne, Professors Dr. G. Blamberger and Dr. D. Boschung, for accepting this study for the MLC series and Dr. Sidonie Kellerer for thorough copy editing. 



\section{THE EARLIEST LATIN TRANSLATIONS OF ARISTOTLE- WILLIAM OF MOERBEKE}

Cicero introduced considerable parts of Greek philosophy in Rome in a systematic fashion. He did so by choosing the literary form of the dialogue in which he presented selected philosophical topics from the viewpoint of different philosophical schools to a Roman audience. The alternative, that of producing Latin translations of Greek philosophical works, he chose to a much lesser degree, and due to the loss of the texts in question we are not well informed about this option. He translated Plato's Protagoras, likely the entire dialogue, and, as part of an intended dialogue on natural philosophy, sections from Plato's Timaeus. In De Finibus I, he writes hypothetically about translating Plato and Aristotle, ${ }^{1}$ but acknowledges that he has not done so yet, however, he does not believe that it is forbidden to him. He wants to limit himself to a translation of "certain passages" (locos quidem quosdam). On rare occasions, we find translations of brief Platonic passages in Cicero's philosophical writings, like that from the Phaedrus (245c5-246a2) in the Somnium Scipionis in De Republica VI 27-28. It is indicative of Cicero's approach to translation that he did not reveal that the section De Republica VI is actually his translation of Plato's text. ${ }^{2}$ Cicero intended De Republica as a counterpart to Plato's Politeia ${ }^{3}$ and the dream of Scipio in the final section of Cicero's De Republica VI was inspired by a myth which is found at the end of the last book of Plato's Politeia.

1 De Finibus I 3.7, cited below n. 113.

2 In other cases, namely translations of only a few lines, Cicero identified the Platonic dialogue from which the passage was taken, so the Gorgias and Menexenos at Tusculanae Disputationes V 12.34-36.

3 De Legibus I 5.15. 
Instead of outlining at the end of this work the Platonic concept of the ultimate principle of motion, Cicero allows Plato to end the treatise by speaking in his own words, only translated by the Roman author of the dialogue.

On the other hand, we do not find in Cicero's philosophical writings comparable translations of works of Aristotle. Could Cicero have composed such a translation? There has been for quite some time an intense scholarly debate about Cicero's knowledge of Aristotle's work. ${ }^{4}$ Paul Moraux has argued that Cicero had access only to the exoteric works of Aristotle, that it is his dialogues, but not the treatises which we now possess as the Corpus Aristotelicum. Specifically, he argues that there is no indication whatsoever that Cicero had read either the Nicomachean Ethics or the Politics. Moraux draws attention to the fact that with regard to Aristotle's ethical and political writings, it is the dialogues of Aristotle, either On Justice or The Statesman (Politikos), Cicero refers to, and not the Politics. ${ }^{5}$ This means Cicero could not have chosen a passage from Aristotle's Politics in order to adorn one of his philosophical works for the simple reason that this work was not known to him. Moraux refers to Cicero's letter to his brother Quintus (Ad Quintum fratrem 3.5.1 from Oct./Nov. 54). There, Cicero writes that, after a reading of a draft of his work on the best state and the best citizen, Sallustius had pointed out that these issues could be discussed with much more authority if he, Cicero, spoke about the state, especially in view of his experience as consul and involvement in state affairs of utmost importance. Sallustius refers then to Aristotle, who presented himself as a speaker in his dialogues to express his views about the state and the leading man. ${ }^{6}$ Moraux infers from this remark that Cicero only knew Aristotle's dialogues. One might object to this line of argument, noting that when Cicero was discussing the role he would play in a dialogue and considering Sallustius' suggestion to

4 Cf. the overview in Moraux 1975, 81 n. 1.

5 Moraux 1975, 94: "Cicéron ne connaît, comme ouvrages politiques d'Aristote, que des ouvrages dialogués; il ne semble pas soupçonner l' existence de la Politique que nous lisons encore."

6 Aristotelem denique, quae de re publica et praestanti viro scribat, ipsum loqui. 
use his own authority in order to add weight to the arguments as Aristotle had done in his dialogues, any reference to a theoretical work of Aristotle was out of question.?

Already in his youth Cicero was engaged in translations, e.g. the rendering of the Aratea. Thus it is not surprising that one often finds reflections on translating in his work. In Academica I he explains the appeal of Ennius, Pacuvius and others by the fact that they did not reproduce the words, but expressed the 'force' or 'meaning' of the Greek poets. 'When dealing with translations of prose texts he is more specific in explaining an alternative to the translation merely of 'words'. Cicero had planned to translate a speech of Aeschines and Demosthenes. In De optimo genere oratorum he remarks briefly on the principles he would follow in his translation. He would not do so as an interpres, but as an orator who does not render verbum pro verbo, but keeps the ideas and the form in which they were expressed while bringing the words into agreement with the convention of the Latin language. ${ }^{9}$ The ideal which Cicero was to follow stresses accuracy and faithfulness, however, not to the individual words but to the sense and its formal expression (sententiis isdem et earum formis). Interpres is almost used in a disparaging sense of someone who pays rather pedantic attention to individual words which is contrasted with the grasp of the whole character of the words and their meaning (genus omne verborum vimque). He addresses a different aspect of the literal translation when he calls interpretes indiserti, "translators without

7 I believe that there are some echoes of Aristotelian phrases in Cicero which could be understood as to suggest that Cicero had read Aristotle's Nicomachean Ethics and Politics. I cannot present the arguments here.

8 Academica I 3.10 qui non verba, sed vim Graecorum expresserunt poetarum.

9 De optimo genere oratorum 5.14 nec converti ut interpres, sed ut orator, sententiis isdem et earum formis tamquam figuris, verbis ad nostram consuetudinem aptis. In quibus non verbum pro verbo necesse habui reddere, sed genus omne verborum vimque servavi. The argument that words chosen should agree with the convention of the Latin language is repeated later at 7.23 when Cicero states that as translator he follows Greek words only so far as it does not conflict with Latin custom (verba persequens eatenus, ut ea non abhorreant a more nostro). 
eloquence. ${ }^{{ }^{10}}$ The literal translation is also rejected by Horace. ${ }^{11}$ Another aspect Cicero had to address is philosophical terminology and in particular the question whether one should try to find Latin equivalents or introduce the Greek terms in transliterations or coin new terms in Latin. ${ }^{12}$ We will return to this in the context of the Latin translations of Aristotle's Politics.

Marius Victorinus (b. before 300 A.D.) was the first to make available the Aristotelian writings on logic through translations into Latin. He translated the Categories and On Interpretation ${ }^{13}-$ both translations are lost. Anicius Manlius Severinus Boethius (c. 480-525) set out an ambitious plan to translate all of Plato's and Aristotle's works into Latin. ${ }^{14} \mathrm{He}$ did not live to carry it out but completed a number of translations (probably before 510 A.D.), including Aristotle's Categories, ${ }^{15}$ On Interpretation ${ }^{16}$ Prior Analytics, ${ }^{17}$ Topics, ${ }^{18}$ and the Sophistical Refutations ${ }^{19}$ He expressed in theoretical terms the principles a translator should adhere to when translating texts in which rerum cognitio is sought, s. below p. 24 .

10 De Finibus III 4.15. In a similar vein Jerome argues that in a literal translation of Homer into Latin one will find the word order ridiculous and Homer, the most eloquent poet, hardly speaking (uidebit ordinem ridiculum et poetam eloquentissimum uix loquentem), ep. 57.5.8.

11 Hor. De Arte Poetica 133 f. nec verbum verbo curabis reddere fidus / interpres nec desilies imitator in artum.

12 Cf. Fögen 2000, on Cic. p. 77-141.

13 Marti 1990, p. 25.

14 Anicii Manlii Severini Boetii, Commentarii in librum Aristotelis MEPI EPMHNEIA , Pars Posterior, secundam editionem continens, ed. C. Meiser, Leipzig 188o, p. 79: mihi autem ... haec fixa sententia est, ut ... ego omne Aristotelis opus, quodcumque in manus venerit, in Romanum stilum vertens eorum omnium commenta Latina oratione perscribam, ut si quid ex logicae artis subtilitate, ex moralis gravitate peritiae, ex naturalis acumine veritatis ab Aristotele conscriptum sit, id omne ordinatum transferam atque etiam quodam lumine commentationis inlustrem, cf. Dod, CHLMPh 1982, p. 53-4.

15 L. Minio-Paluello, Aristoteles Latinus I 1, Bruges - Paris 1961. In this volume the translation of this Aristotelian work by William of Moerbeke can be found as well.

16 Id. Aristoteles Latinus II 1, Bruges - Paris 1965.

17 Id. Aristoteles Latinus III 1, Bruges - Paris 1962.

18 L. Minio-Paluello - B.G. Dod, Aristoteles Latinus V 1, Bruxelles - Paris 1969.

19 B.G. Dod, Aristoteles Latinus VI 1, Leiden - Bruxelles 1975. 
It took more than half a millennium until the initiative of translating Greek originals of Aristotelian works into Latin got a fresh start. James of Venice (Jacobus Veneticus Grecus, first half of the $12^{\text {th }}$ cent.), who produced an important translation of the Posterior Analytics, has been regarded as the first systematic translator of Aristotle after Boethius..$^{20}$ Bartolomeo da Messina translated Aristotle's Magna Moralia by the middle of the $13^{\text {th }}$ cent. ${ }^{21}$ Robert Grosseteste's († 1253) translation of Aristotle's Nicomachean Ethics (1245-1247), which was used by Albertus Magnus, was accompanied by Latin translations of Greek commentaries on this work. ${ }^{22}$ Leonardo Bruni (1369-1444) rejected this translation, and its poor quality, as he felt, made him not only justify the need for his own translation but write a treatise, De Interpretatione recta, in which he identified and criticized the shortcomings of the earlier translation and outlined the requirements a translation into Latin must meet (s. below p. 28 ff.).

A number of these Aristotelian works that were translated from Greek into Latin for the first time had already been available in Latin as translations from Arabic, ${ }^{23}$ with a few notable exceptions, among them Aristotle's Politics. ${ }^{24}$ In 1255 at the

20 Berschin 1980, p. 258; Dod, CHLMPh 1982, p. 46-7; 54-5.

21 Berschin 1980, p. 293; Dod, CHLMPh 1982, p. 49; 62.

22 Berschin 1980, p. 294 f. Cf. H.P. F. Mercken, The Greek commentaries on the Nicomachean Ethics of Aristotle in the Latin translation of Robert Grosseteste, Bishop of Lincoln ( $\dagger$ 1253), in: Corpus Latinum commentariorum in Aristotelem Graecorum, 3 vols., Leuven 1973-1991; Dod, CHLMPh 1982 , p. 61.

23 By Gerhard of Cremona in the middle of the $12^{\text {th }}$ cent. or by Michael Scotus by 1220, s. Dod, CHLMPh 1982, p. 47-50; 58-9.

24 R. Newald, Nachleben des Antiken Geistes im Abendland bis zum Beginn des Humanismus, Tübingen 1960, p. 225: Almost the complete work of Aristotle was available to Averroës, except for the Politics. This reflected the knowledge the Arabic tradition had of Aristotle's writings, cf. Flüeler 1992, vol.1, p. 10; Rémi Brague, "Note sur la traduction arabe de la Politique d'Aristote, derechef, qu'elle n'existe pas," in: P. Aubenque - A. Tordesillas Aristote Politique. Etudes sur la Politique d'Aristote, 1993, 423-33; V. Syros, "A Note on the Transmission of Aristotle's Political Ideas in Medieval Persian and Early-Modern India. Was there any Arabic or Persian Translation of the Politics?", Bulletin de philosophie médiévale 50 (2008), 303-09. 
University of Paris in the faculty of artists, almost the complete works of Aristotle were part of the curriculum but his Politics are not mentioned. ${ }^{25}$ The Flemish Dominican William of Moerbeke (c. 1215-1286), archbishop of Corinth in Greece in 1278, left behind a monumental record of translations that included not only works of Aristotle but those of his commentators as well, and of Archimedes, Ptolemy, Galen and of the Neo-Platonist Proclus. Some of these works were translated by William into Latin for the first time, among them Aristotle's Politics. ${ }^{26}$

Two versions of William's translation of the Politics exist. The Translatio prior or imperfecta, dating to the period between 1255 and $1261{ }^{27}$ which is incomplete (it ends at II 11 1273a30) since this is all William's manuscript contained, ${ }^{28}$ and the Translatio integra or completa, the complete translation of the Greek text of the Politics as we have it. ${ }^{29}$ Gérard Verbeke ${ }^{30}$ has undertaken a detailed comparison of a number of passages of the two translations and concluded that the second version is remarkably superior over

25 S. Flüeler 1992, vol. 1, p. 1 f.; 23. There are a few references to Aristotle Politics between the $2^{\text {nd }}$ and $5^{\text {th }}$ cent. A.D., and only in the $11^{\text {th }}$ cent., starting with Michael of Ephesus, knowledge of Politics resurfaces, s. A. Dreizehnter, Aristoteles' Politik. Eingeleitet, kritisch herausgegeben und mit Indices versehen, Studia et Testimonia antiqua 7 1970, p. XVIII-XX; 227.

26 Dod, CHLMPh 1982, p. 62-68; ibid. p. 63: he was the first to translate De motu animalium, De progressu animalium; Politics, Poetics. Cf. now Vanhamel 1989, p. 301-383, in particular p. 319 ff.: "\3. Liste annotée des œuvres de Moerbeke et aperçue bibliographique" (p. 339-341 on the translation of the Politics).

27 Flüeler 1992, vol. 1, p. 23; 28.

28 Cf. Michaud-Quantin, Aristoteles Latinus, XXIX i, 1961, p. IX-X.

29 I cite from the edition by F. Susemihl 1872 . The edition by L.-J. Bataillon-H.-F. Dondaine 1971 as part of the edition of the commentary on Arist. Politics by St. Thomas, contains William's translation only to III 8 1280a5. -F. Bossier, "Méthode de traduction et problèmes de chronologie," in Brams - Vanhamel 1989 (p. 259-294), p. 292, argues on the basis of William's use of certain conjunctions and adverbs, that this version was completed before the middle of the year 1265; cf. as well Brams 1989, p. 329-335: "Problèmes de chronologie;" Flüeler 1992, vol. 1, p. 23-29: before 1267/8.

30 Verbeke 1989, p. 1-21. 
the first one. First of all, William had access to a better Greek text when he undertook the second translation, and his ability to decipher and read the Greek manuscript may have improved when he was working on the second version. Verbeke observed more significant improvements. In the first version, numerous Greek words were simply transliterated ${ }^{31}-$ obviously because William did not yet know their exact meaning whereas in the second version many of them have been replaced by Latin words. On the whole, Verbeke recognizes William's effort to make the translation easier to understand, which reveals William's attention not just to the meaning of individual words but as well to the meaning of phrases in their context, that is to the content of the text, indicating a better understanding of the work he translated.

While it is correct to conclude on the basis of a comparison of the two versions of William's translation that the improvements in the second version are considerable, ${ }^{32}$ still the quality of the Latin is lacking by the standards of classical Latin prose literature (which will be applied by Bruni). William follows the Greek text verbum e verbo ${ }^{33}$ and it has been said: "the Latin is clumsy and sometimes unclear" ${ }^{34}$ and the translation is "literal to a fault. ${ }^{\prime 35}$ The intended meaning of William's translation may be better understood if the reader tries to figure out which words and sentence structure the Greek text had. One might even fail with this. "To grasp fully his meaning one must often refer to the Greek text to which, of course, his readers had no access." ${ }^{36}$

William's close adherence to the Greek original has been used by editors of Aristotle's works to emend the Greek text

31 Cf. Michaud-Quantin, Aristoteles Latinus, XXIX i, p. XII.

32 "les ameliorations sont considérables", Verbeke 1989, p. 10.

33 In the Liber de memorabilibus sive Chronicon Henrici de Hervordia (of 1355), ed. A. Potthast, Göttingen 1859, 203, one finds already the remark about Wilhelm: frater Wilhelmus Brabantinus, Corinthiensis ... transtulit omnes libros Aristotelis naturalis et moralis philosophiae et metaphysicae de graeco in latinum, verbum e verbo (cited by Grabmann 1946, p. 65 f.), cf. Steele 1989 , p. 58.

34 Schmitt 1983, p. 155 n. 21.

35 Menut 1970, p. 24.

36 Schmitt 1983, p. 155 n. 21. 
transmitted in the manuscripts ${ }^{37}$ which were copied later than the date of William's translation. However, it is not advisable to assume that there is something wrong with the transmitted Greek text whenever there is a discrepancy with William's translation. Aristotle begins his Politics by identifying the genus to which the polis belongs, namely a community, and argues that the community that strives after the highest good is the polis, the political community. The Greek text uses both in lines a1-2 and

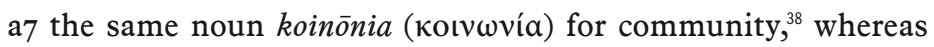
William changes from communitas a1 to communicatio a7. ${ }^{39}$ There is no reason to assume that Aristotle used different nouns here.

Verbeke pointed to the tendency to replace transliterated words used in the first version with Latin words in the second one as one aspect of progress in William's translation. However, many Greek

37 Cf. Susemihl 1872, p. VI: " $\Gamma$, i.e. liber deperditus ..., ex quo originem deduxit vetusta translatio Latina, quam saeculo XIII ${ }^{\circ}$ fecit frater Guilelmus de Moerbeka ... tam fideliter et accurate verbum e verbo reddens, ut raro quid in codice suo legerit dubitare queas." In the Iuntina edition of St. Thomas' commentary of Arist. Politics, Venice 1568, the translation of Wilhelm of Moerbeke was replaced by that of L. Bruni, however the editor, Iulius Martianus Rota, adds as an appendix antiquam Politicorum interpretationem, giving two reasons, first that St. Thomas' commentary was based on that translation, second, quod, cum Aristotelem ad verbum interpretetur, agnoscere possumus, quale tum temporis exemplar haberetur et inde libros quos nunc habemus, tam graecos, quam latinos, emendare $\left(133^{\mathrm{v}}\right)$. He added punctuation and divided the text up into lectiones, ut si quis velit ... graecos codices emendare, commoditate fruatur, nec diutius in querendo laboret. P. Vettori consulted for his edition of the Rhetoric of 1548 William's translation, s. Schneider 1971, p. 73-76.

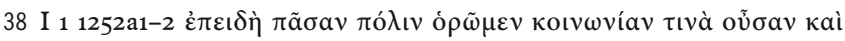

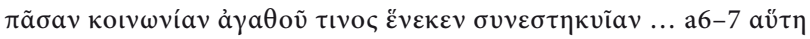

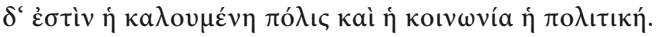

39 Quoniam omnem civitatem videmus communitatem quandam existentem ... haec autem est quae vocatur civitas et communicatio politica. The Translatio imperfecta, however, did not make this change from communitas to communicatio when it presented: ipsa autem est que vocatur civitas et omnis communitas politica, Aristoteles Latinus, XXIX i, p. 3. Communicatio is used again at I $21252 \mathrm{~b} 15$, p. 5.6 ed. Susemihl, but communitas b28, p. 6.9 ed. Susemihl. For William's translation of the Rhetoric, s. Schneider 1971, p. 72: "Für dasselbe griechische Wort steht in seiner Version keineswegs immer dasselbe lateinische Wort.“ 
words were left in the revised version, among them kalokagathia. ${ }^{40}$ Verbeke ${ }^{41}$ justified this decision because kalokagathia stands for an ideal of classical Greek culture, whereas the ideal person of the $13^{\text {th }}$ cent. A.D. was no longer the same as the one of Aristotle's time.

At best, a transliteration like that of kalokagathia can highlight the foreign character of a term or concept and draw attention to it. If done discretely and with good judgment, a philosophical text may benefit from this approach because important terms are marked and receive attention. Indeed, some terms in a text to be translated are so specific that they lack an equivalent in the language of the translation so it is desirable to leave them untranslated because a new word coined after a Greek term could be adopted by the other language. A passage in Cicero Academica $\mathrm{I}^{42}$ reveals that a number of Greek philosophical terms had become part of the Latin language in his time, however, the interlocutor Varro made an effort "to speak Latin" when expounding Greek philosophy and was very reluctant to expand the Latin vocabulary, e.g. when introducing the term qualitas-a word that entered English, French, and German. We owe the words consistentia, exsistentialis, inexsistens, and identitas ${ }^{43}$ to the translations of Marius Victorinus, all of which had a remarkable fortuna.

40 Politics I 13 1259b34 f.; William p. 52.6 ed. Susemihl.

41 Verbeke 1989, p. 8.

42 Academica I 7.25 f. 'Nos vero' inquit Atticus; 'quin etiam Graecis licebit utare cum voles, si te Latina forte deficient.' Va. 'Bene sane facis; sed enitar ut Latine loquar, nisi in huiusce modi verbis ut philosophiam aut rhetoricam aut physicam aut dialecticam appellem, quibus ut aliis multis consuetudo iam utitur pro Latinis. Furthermore, every technique has its specific vocabulary. Therefore, aut enim nova sunt rerum novarum facienda nomina aut ex aliis transferenda. quod si Graeci faciunt qui in his rebus tot iam saecla versantur, quanto id nobis magis concedendum est, qui haec nunc primum tractare conamur.' 'Tu vero' inquam 'Varro bene etiam meriturus mihi videris de tuis civibus, si eos non modo copia rerum auxeris ut effecisti, sed etiam verborum.' Va. 'Audebimus ergo' inquit 'novis verbis uti te auctore, si necesse erit. Then he uses initia for Greek archai, adding ut e Graeco vertam. Cf. later about the Platonic 'form': hanc illi i $\delta \varepsilon \dot{\alpha} v$ appellabant, iam a Platone ita nominatam, nos recte speciem possumus dicere (8.30).

43 Marti 1990, p. 25 f. Marti, p. 26 n. 9, points out that the coinage of new terms in Latin follows obviously the morphology of the Greek when 
Verbeke did not offer a convincing defense of William's strategy of retaining Greek words in transliteration. First, he did not limit transliterations to the sort of terms to which Verbeke's arguments would apply. William appears to use transliterations more at random; they seem necessitated by his verbum e verbo translation and used whenever he did not seem to have a Latin equivalent at his disposal for the Greek word found in his source. ${ }^{44}$ Secondly, translators of any period are confronted with the challenge of rendering concepts belonging to different eras and cultures for which there exists no perfect equivalent in their languages-the modern ideal of a man is probably even farther removed from that of the classical Greek era than that of the Medieval ages, and one could then generally justify transliteration as a legitimate translation strategy when a text to be translated belongs to a culture different from that of the translator. However, transliterations do not seem to be the appropriate response to this problem which most translators face. From the perspective of the reader, transliterations of words interrupt the flow of a sentence or argument in the language into which the translator translates. In style, such a text lacks homogeneity and consistency. From the point of clarity, the transliteration of a word is counterproductive since it introduces a term unknown to the reader who is not familiar with the original language of the text. In this sense, a transliteration creates obscurity, a criticism voiced by Bruni. In his letter to the Archbishop of Milan, ${ }^{45}$ Bruni identifies two flaws in the old translation: "Words were ... either left as they were found in Greek, or they were placed differently in Latin than they will be placed by me" (verba ... aut relicta sunt in Graeco, ut iacebant, aut aliter posita sunt in Latino, quam a me ponantur). As

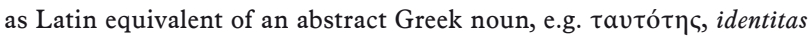
is chosen. Following the same principle, William of Moerbeke will render $\delta \rho \tilde{a} \mu \alpha$ by actitamen, Minio-Paluello 1972, p. 52.

44 This was already recognized by Bruni, see below p. 38 n. 148. Vettori, in the preface to his commentary of Arist. Rhetoric, gives two reasons for William's habit of keeping Greek words: cum aut vim eorum non perciperet, aut, quomodo uno verbo reddi possent, non videret (cited by Schneider 1971, p. 74).

45 Of 1438 (book 8.2 Luiso p. 137 f.) -for the passage quoted s. no. 5, p. 202 ed. Birkenmajer. 
an example of the first point, that words are left in Greek, he cites the Greek word eutrapelia, which is kept by the previous translator but translated by Bruni as comitas. For kalouskagathous Bruni chose the translation honestos et bonos ${ }^{46}$ and did not leave the impression that the Greek ideal had no counterpart in the Latin language. A different strategy used by translators was to add to the word they simply transliterated an explanation, as found in the Translatio vetus of Aristotle Rhetoric, e.g. at II $171391 \mathrm{~b} 2$ philothei id est amici deorum. ${ }^{47}$

James Schmidt sees in "Moerbeke's strategy of translation ... the considerable virtue of making it unmistakably clear where the language of the classical polis resists translation into that of the medieval civitas. When he found terms which could not be rendered into Latin he simply transliterated them from the Greek", that is to say, he provides the historian with "clearly marked stress points." I am not convinced that there is such a rational principle behind all the cases in which William chose to transliterate words. ${ }^{49}$ One needs to point out that after all he actually chose to translate polis by civitas (I 1 1252a1) and does not always leave politikos untranslated but chose civilis as well. The famous statement in Politics I 2 that "man is by nature an animal destined to live in a polis" is translated by him as homo natura civile animal est (p. $7.6 \mathrm{f}$. ed. Susemihl, s. below p. 43). William does not approach transliteration consistently. In any case, a translation that uses transliterations of words reminds the reader constantly that the text is a translation and stresses the foreignness of its content. It asks for additional clarification, which was the assumption in the scholastic tradition that separated the faithful, but not always clear, translation from the expected additional step of explanation, expositio (s. below p. 67).

Similar to transliterations is William's strategy of creating new Latin words based on Greek etymology. Cicero had taken a moderate position on this issue, mindful of the fact that in spite of the richness of the Greek vocabulary, the Stoics had invented

46 Arist. Politics IV 8 1293b39, Bruni ed. 1469 f. $13^{\mathrm{v}}$; Politics II $91271 \mathrm{a} 23$ translated Bruni ed. 1469 f. $108^{\mathrm{r}}$ bonos et honestos.

47 S. Schneider 1971, p. 18. S. below p. 27 n. 87.

48 Schmidt 1986, p. $313 \mathrm{f}$.

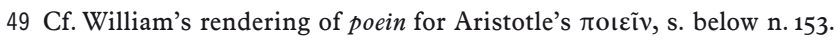


many new terms. Therefore, the Romans could do the same. ${ }^{50}$ The situation is, however, different after Cicero had expanded the Latin philosophical vocabulary. Under these circumstances it becomes more difficult to justify the coinage of new terms (s. below p. $32 ; 39$ n. 149). Bruni pays particular attention to it and rejects William's practice vehemently, e.g. his translation of Greek

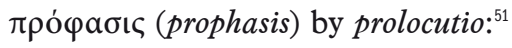

What does it mean, I ask you, "to speak for the sake of prolocution"? For if men speak to the people in a wise manner for the sake of prolocution, prolocution must indeed be something important. Therefore, instruct me, what it is. For until now I have never heard or read this word and I don't understand what it means..$^{52}$ If in a most far-off country of barbarians this word is in use, instruct me, what it means among barbarians "to speak for the sake of prolocution." For I whose language is Latin do not understand your barbaric language..$^{53}$

50 De Finibus III 2.5, cf. 4.15.

51 According to $T L L$ vol. X, col. 1832, it is used by Claudius Mamertinus ( $4^{\text {th }}$ cent. $\mathrm{AD}$ ) in the meaning: actio vel potius effectus proloquendi, effa-

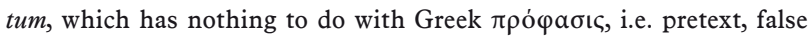
promise. In DuCange, Glossarium mediae et infimae Latinitatis, vol. 6, p. 528, only one reference is given, in the meaning of colloquium. Differently Griffiths, Hankins, Thompson 1987, p. 374 n. 16: measured by the standards of medieval Latin, Bruni "somewhat tendentiously" overstated his criticism. However, it is quite ironic that Bruni himself did not know the meaning (and etymology) of $\pi \rho$ ó $\varphi a \sigma ı \varsigma$ when he translated

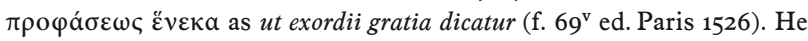
thought it was derived from the Greek verb pávaı instead of paíveıv, cf. p. Chantraine, Dictionnaire étymologique de la langue grecque: histoire des mots, Paris 1968-1980, 4 vols., p. 1171 s.v. paívw.

52 Bruni repeats this criticism with regard to William's choice of leaving epiichiam in Greek: Cur tu ergo mihi 'epiichiam' relinquis in greco, verbum mihi ignotum? De Interpretatione [44] p. 120, cf. below p. 35 n. 131.

53 Quid est queso 'prolocutionis gratia loqui'? Si enim loquuntur homines ad populum sapienter gratia prolocutionis, magnum profecto aliquid debet esse prolocutio. doce me ergo, quid tandem sit! Nam ego id verbum numquam audivi hactenus neque legi nec, quid importet, intelligo. Si in extrema barbarie id verbum in usu est, doce me, quid apud barbaros significet 
William adopted a different strategy with regard to a different kind of a Greek compounds, i.e. adjectives that consist of two stems. Here, he translates one part, but leaves the other part

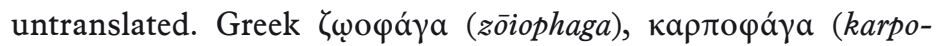

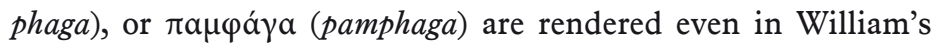
second version as animalifaga, fructifaga or omnifaga respectively, ${ }^{54}$

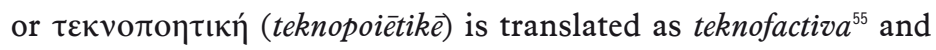
iootúpavvov (isotyrannon) as aequityrannum. ${ }^{56}$ Introducing such hybrid forms was not a common practice of medieval translators of Aristotle as L.J. Bataillon ${ }^{57}$ has pointed out. He draws attention to the fact that e.g. R. Grosseteste replaced eufortunium found in a previous translation of Aristotle's Nicomachean Ethics with bona fortuna (p. 297)-William will return in his translation of Aristotle's Poetics of 1278 to eufortunium. ${ }^{58}$ When William found in Boethius' earlier translation a rendering that avoided such hybrid words, he opted for re-introducing the hybrid form in his revision of that translation. ${ }^{59}$ John the Scot (c. $815-877$ ) had remarked that there is no way to express Greek terms like homoousion, homoagathon or homotheon in a single Latin word. He decided to translate these by separate words since a translation that renders one word by one word fails. ${ }^{60}$ William seems to adhere

'prolocutionis gratia loqui'. Nam ego latinus istam barbariem tuam non intelligo, Bruni, De Interpretatione [33] p. 106-108, on the phrase prolocutionis gratia loqui found in William's translation (p. 428.3 ed. Susemihl) of

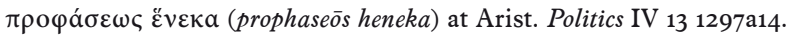

54 Arist. Politics I 81256 a25, s. William p. 29.11 ed. Susemihl. Equally unattractive, or cacophonous, is William's rendering iamboficus for Arist. iambopoioi, Poetics 8 1451b14; Minio-Paluello 1972, p. 52.

55 Arist. Politics I 3 1253b10; William p. 11.12 ed. Susemihl.

56 II 91270 ob13 f.; William p. 123.3 ed. Susemihl, s. below p. 41 with n. 160.

57 L.J. Bataillon, "L'usage des mots hybrids Gréco-Latins par Guillaume de Moerbeke," in: Brams - Vanhamel (eds.) 1989, p. 295-299.

58 Minio-Paluello 1972, p. 52.

59 Minio-Paluello 1972, p. 174, points out that $\psi \varepsilon v \delta o \gamma \rho a ́ \varphi \eta \mu \alpha$ of Arist. Sophistical Refutations I $11171 \mathrm{~b} 12 \mathrm{f}$. is translated falsa descriptio by Boethius, but falsigraphia by William. Ibid. p. 50 Minio-Paluello calls these forms "caratteristiche di Guglielmo".

60 J. Scotus, De Divisione Naturae II, in PL vol.122, col. 567 C Quorum interpretatio de verbo ad verbum non exprimitur. 
with regard to the word by word translation to a more purist, almost an extreme position whereas others like Boethius and John the Scot were willing to compromise.

One notices that William was aware of the meaning of individual Greek and Latin words. Aristotle at the beginning of the first chapter of Politics VII demands that a study of the best state required that one first explains the best life ${ }^{61}$ what I paraphrased

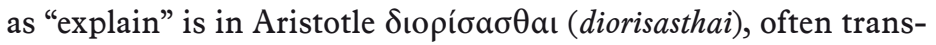
lated as "define." William of Moerbeke chose the translation $d e-$ terminare. The stem termin- corresponds exactly to that of the

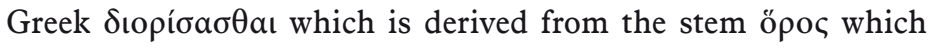
means "boundary, border". Not only is the semantic nuance of the Greek verb well preserved by William, but he seems to attempt to reproduce the etymology of the Greek word as well. Jerome (ca 340-420 A.D.) reveals that Aquila of Sinope (2nd cent. A.D.) in his translation of the Hebrew Bible into Greek tried not only to transfer the words but their etymology as well..$^{63}$ This is generally William's objective which almost allows translating his rendering back into Greek. Aristotle's $\sigma u ́ v \tau \alpha \xi ı \varsigma ~(s y n t a x i s)$ is in William's translation coordinatio. ${ }^{64}$

L. Minio-Paluello concisely described the difference between the approaches to translation followed by Boethius and William respectively: "Boethius wanted to translate Aristotle into Latin, Wilhelm wanted to accomplish that the Greek be read in Latin letters. ${ }^{95}$ This method does not necessarily reveal a poor

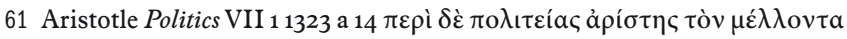

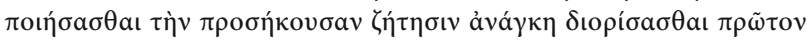

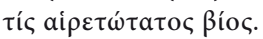

62 Liddell - Scott - Jones, A Greek-English Lexicon, ${ }^{91996, ~ s . v . ~ \delta ı ~}$

63 Aquila autem, proselytus et contentiosus interpres, qui non solum uerba, sed etymologias uerborum transferre conatus est, iure proicitur a nobis, ep. 57.11.2.

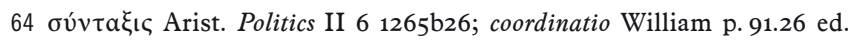
Susemihl, s. below p. 41.

65 Minio-Paluello 1972, p. 174: "Boezio voleva rendere Aristotele in latino, Guilelmo voleva far legger il greco in lettere latine”. A similar judgment as the one quoted about Wiliam, Minio-Paluello expressed about Robert Grosseteste (1950), ibid. p. 111. 
command of Latin on the part of William or a lack of understanding of Latin word order and syntax but an approach sanctioned by a tradition of the ideal of the fidus interpres, as it was observed by Jerome (c. 347-420), although for him this applied only to a translation of the Holy Scriptures. ${ }^{66}$ In these texts the word order is a mystery ${ }^{67}$ that transcends human comprehension. It would be presumptuous for a translator to allow his limited understanding to potentially distort the truth of the authoritative text that has been made known through revelation. The word by word translation is the best guarantee against alterations of the original thought. The translation should be a copy of the original in a different language. The translator eliminates the possibility of misrepresenting the original and accepts the subordinate role of the interpreter who seeks to offer equivalent words for those of his source in the translation. The imperative for the translation is the closest adherence to the source not only in word order but also number of syllables if possible, without regard to the quality of style. Jerome's $e p .57$ (of 395 A.D.) reveals that this method of translation was expected by some to be followed even outside of the Scriptures because Jerome felt compelled to defend himself against the accusation that in translating Epiphanius' letter to John of Jerusalem he did not adhere to this method of translation. ${ }^{68}$ Jerome is not apologetic about the fact that, except for the translation of the Scriptures in which he translated verbum $e$ verbo, in translations of other Greek texts he expressed the sense of the text (ep.57.5.2) ${ }^{69}$ and this, as he writes, was the method he adopted from his youth. ${ }^{70} \mathrm{He}$ justifies it by referring to Cicero and Horace (s. above p. 12 n. 11). The verbum e verbo approach was limited to translations of the Scriptures. William of Moerbeke goes

66 S. Schwarz 1944, 73-77; Harth 1968, 45-56. For a nuanced discussion of the rather complex views of Jerome on translation s. Adler 1994.

67 Jerome $e p \cdot 57 \cdot 5 \cdot 2$.

68 Ep.57.2.3 me verbum non expressisse de verbo.

69 Jerome ep.57.5.2 libera voce profiteor me in interpretatione Graecorum absque scripturis sanctis, ubi et verborum ordo mysterium est, non verbum e verbo, sed sensum exprimere de sensu.

70 Ep. 57.6.1 me semper ab adulescentia non uerba, sed sententias transtulisse. 
further in his translation of Aristotle's works where he applies the ideal of the fidus interpres, originally reserved for translations of biblical texts, to the translation of philosophical works. He was not the first to do so. Boethius, in his commentary of the Isagoge Porphyrii, justifies a translation of verbum verbo with the argument that in works in which understanding of things is sought (in quibus rerum cognitio quaeritur) the uncorrupted truth and not the charm of a lucid style must be expressed.1

Jerome, as we saw (above n. 69), distinguished a verbum e verbo translation that is applied in the rendering of the Scriptures from a less literal translation he preferred in order to expresses the sense of Greek texts other than the Scriptures. The alternatives of either being faithful to the words or to the sense had already been expressed by Cicero in De optimo genere oratorum, and it is this work and the lines quoted above from Horace that Jerome cites when he justifies the translation that conveys the sense of the source. For Boethius, however, this alternative strategy adopted by Jerome is no longer viable, he "was the first to proclaim the principle of word-for-word translation for books that are not sacred." ${ }^{\text {"2 }}$ Alfonso of Cartagena (1384-1456), later bishop of Burgos, will defend this concept of translation against the criticism of Bruni and his style of translating Aristotle (s. below p. $66 \mathrm{f}$.).

Moerbeke's translation was the text on which Thomas of Aquinas and Albertus Magnus based their commentaries on Aristotle Politics. ${ }^{73}$ Political writings by a number of Medieval authors like John Quidort (c. 1255-1306), Dante (ca. 1265-1321), Marsilius of Padua (ca.1270-ca.1342), and Nicolaus of Cusa (1401-1464) reveal knowledge and influence of Aristotle's Politics. There is a scholarly dispute about the degree of the impact Aristotle had. This question lies outside of the present study. A balanced view has been proposed by Francisco Bertelloni ${ }^{74}$ who argued that the

71 In Isagogen Porphyrii commenta, ed. secunda, I 1, CSEL vol. 48, 1906, p. 135.

72 Schwarz 1944, p. 75.

73 Thomas had been the first to use the new translations of William: Steele 1989, p. 62; for the date of Albertus' commentary s. ibid. p. 65 f.

74 Bertelloni 2007; cf. Ch. Flüeler, "Politischer Aristotelismus im Mittelalter," Vivarium 40 (2002) p. 1-13. 
work of these thinkers was not only influenced by Aristotle's political and ethical philosophy but by earlier and contemporary legal, theological and other philosophical concepts as well. And some of these authors introduced 'protomodern' ideas that go beyond Aristotelian thinking while the knowledge of Aristotle's political and ethical philosophy enabled them to express the new topics of their political theory in a clearer and better suited terminology.

\section{NICOLE ORESME}

An attempt to translate the Latin version of Aristotle's Politics by William of Moerbeke into French was made by Master Pierre de Paris around 1305. This translation is not preserved. William of Moerbeke's translation was used by Nicole Oresme (c. 1323-1382) who produced in the second half of the $14^{\text {th }}$ cent..$^{75}$ a translation of Aristotle's Politics into a modern language, French. ${ }^{76}$ His was the first translation of the Politics into a vernacular. King Charles $\mathrm{V}$, at whose behest Oresme produced this translation, was aware that he could not reach the leading nobility, who would benefit from the study of the Aristotelian Politics, in the Latin language. The topics and theoretical concepts Nicole Oresme found in Aristotle's Politics had never been dealt with before in the French language. ${ }^{77}$ It has been said that Nicole Oresme had to invent the target language. ${ }^{78}$ Nicole Oresme was aware of the difficulties linked to a French translation of the Politics. In the proem to his

75 Menut 1970, p. 19 f., shows that the first version of the translation by Nicole Oresme was completed already at the end of the same year in which it was begun, in 1371. The following two revisions, with mostly minor changes, affected the commentary and were completed in 1374 .

76 It has been edited by Menut 1970. For translations into a vernacular s. ibid. p. 26-30. The most recent chapter on Oresme is Gregorio 2008, p. 112-133 with extensive bibliography.

77 He benefited from the commentary on the Politics by St. Thomas, s. Menut 1970, p. 25; cf. Verbeke 1989, p. 12 n. 20; 13 n. 23. However, Oresme took over some mistakes too he found there: Verbeke, p. 14 n. 25.

78 Gregorio 2008, p. 118. 
translation of the Nicomachean Ethics Nicole Oresme compares the two languages and puts Latin ahead of French in its perfection and abundance of vocabulary. ${ }^{79}$ It is remarkable that Nicole Oresme reminds here of the comments of classical Roman authors concerning the difficulties of introducing Greek philosophy to Roman readers in their language. ${ }^{80}$ Oresme has been credited with enriching the French language with more than 1.000 words, $30 \%$ of which are still used today. ${ }^{81}$

With regard to the approach to translating, one could argue that Nicole Oresme followed the practice of William of Moerbeke who at times simply transcribed a Greek word and attached the endings of Latin morphology, e.g. monarchizabant. ${ }^{82}$ William's democratizar ${ }^{83}$ becomes in Nicole Oresme democratizer. ${ }^{84}$ And at the beginning of the first chapter of Politics VII to which I referred already (p. 22), Aristotle states that those who enjoy the best political conditions lead the best life. The Greek expression "enjoy

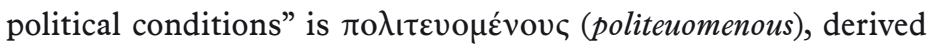

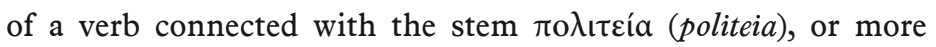

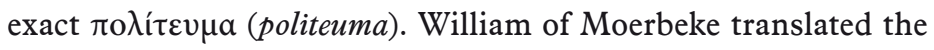

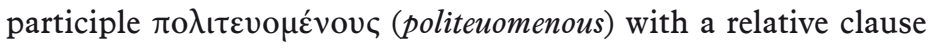
qui politizant, where the verb is a neologism ${ }^{85}$ taken over directly from the Greek. Here and often elsewhere, Nicole Oresme simply continued this practice of leaving words untranslated when he took over the Latin word found in William of Moerbeke's translation and added the endings of a French verb. ${ }^{86}$ William's qui politizant becomes qui politizent et gouvernent tres bien-the

79 Menut 1970, p. 27.

80 E.g. Lucretius, De Rerum Natura I 139, cf. Fögen 2000.

81 Menut 1970, p. 11; 28. The influence of Nicole Oresme's translation of the Politics could be compared with the impact the translation of the bible by Martin Luther had in Germany.

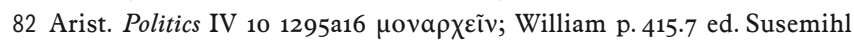
monarchizabant.

83 Translation of Politics VI 5 1320a3, p. 475.6 ed. Susemihl.

84 Oresme p. 266 col. 1 ed. Menut.

85 It is not listed in $T L L$ or in Du Cange.

86 Menut 1970, p. 28. 
awkwardness of the neologism politizent is mitigated by the explanatory et gouvernent tres bien. ${ }^{87}$

However, given the success of Nicole Oresme's coinage of new words-among them the very word "politique" ${ }^{88}$ - he cannot be accused of a 'barbarous' practice, of a poor use of the language into which he was translating, as Humanists have characterized the earlier medieval translations into Latin. ${ }^{89}$ Just the opposite: he displays good judgment in minor details. Aristotle's expres-

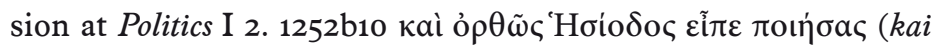
orthōs Hēsiodus eipe poiēsas) was translated by William as et recte Hesiodus dixit poetizans ${ }^{90}$, but by Nicole Oresme as "et pour cet disoit bien Esiodus en parlant comme poëte." ${ }^{\text {11 }}$

Nicole Oresme's translation was successful enough so that it took almost 200 years until in 1568 Louis Le Roy issued a new translation of Aristotle's Politics into French which made that of Nicole Oresme obsolete. ${ }^{92}$

87 S. Menut 1970, p. 28 . There is a tradition of "lezioni doppie", that is of explaining one Greek word by two terms in the translation, connected by seu, vel or id est, cf. Minio-Paluello 1972, p. 51; 108-111; Schneider 1971, p. 19 f., s. above p. 19.

88 Menut 1970, p. 28. The German word "Politik" with the stress on the last syllable goes back to French "politique" (see J. Grimm - W. Grimm, Deutsches Wörterbuch, vol.7, Leipzig 1889, col. 1979) - "politique" was introduced into the French language by Nicole Oresme. Ultimately the German term owes its existence to Nicole Oresme's translation of Aristotle's Politis.

89 Bruni will argue that the Latin language possessed words for everything that was expressed in Greek, cf. De Interpretatione [43] p. 120; s. below p. 39 with n. 149. For Bruni's charge of barbarism against the translation of William cf. ibid. [11] p. 82; [33] p. 106; [42] p. 118, cf. Bruni, Praemissio Ethicorum p. 76-77 ed. Baron, translated by Griffiths, Hankins, Thompson 1987, IV:2, p. 213; Praemissio Politicorum p. 74 ed.Baron, translated by Griffiths, Hankins, Thompson 1987, II 7:VI, p. 162-164; Bruni's letter to F. Picolpassi of Oct. 15 1435, book 7.4 (p. 127 f. Luiso), no 3, p. 191 ed. Birkenmajer. This charge is repeated by Vettori regarding William's translation of Arist. Rhetoric in the preface to his commentary, cited by Schneider 1971, p. 74 .

90 p. 4-5 Susemihl.

91 p. 47 Menut.

92 Menut 1970, p. 30; Gregorio 2008, p. 112 n. 4. 


\section{LEONARDO BRUNI'S PRINCIPLES OF TRANSLATION}

In the second half of the $14^{\text {th }}$ cent. Oresme produced a translation of Aristotle's Politics into a modern language in order to reach the leading nobility which was to benefit from the study of this work. Leonardi Bruni d'Arezzo (1369-1444) addressed a somewhat different audience ${ }^{93}$ with his translation of the Politics into Latin from the year $1437 .^{94}$ The language Bruni employed was not the vernacular, ${ }^{95}$ into which by the end of the $13^{\text {th }}$ century not only

93 Hankins 2003, p. $180 \mathrm{f}$. describes this as the upper class in Italian city states who had received a humanist education and would now have access to translations that were "written in a style similar to the classical authors he had learned to enjoy in school."

94 Griffiths, Hankins, Thompson 1987, p. 379 n. 24, cf. Baron 1928, 175 f.

95 R.R. Bolgar, The classical Heritage and its Beneficiaries, Cambridge 1958, p. 277, argued that the first translators from the Greek were "popularisers ... they wrote less for the learned specialists than for the common mass of educated men", but is not "the common mass of educated men" a contradictio in adjecto? Hankins 2006b, p. 133-147, considers Bruni's activity of "discarding the difficult medieval version and retranslating the work into a more accessible literary Latin" as an attempt "to popularize Aristotle's Ethics." Bruni's decision to produce a better Latin translation than his predecessors should not be construed as part of an elitist movement. Hankins rejects the interpretation that Bruni's literary activity appealed only to an audience of professionals who read Latin and points out that many of Bruni's Latin texts were translated into the vernacular (s. Hankins in: Griffiths, Hankins, Thompson 1987, p. 45 with n. 162 on p. 353-355). Hankins makes the same arguments in: 2006a. However, it was really beyond Bruni's control that some of his Latin translations were translated by others into a vernacular, which goes to show that there was a demand for such translations. As $D e$ Interpretatione reveals Bruni was deeply irritated (he felt "felt pain and anger", s. below p. 34 n. 126) by the poor quality of the medieval translation, and this should be believed. It was after all a disagreement about the proper use of Latin which Bruni allowed to cause serious tensions with Coluccio Salutati, his former patron, cf. Witt 2000, p. 395-398. Bruni's claim was to enable those who knew Latin but not Greek to read Aristotle: Praemissio Politicorum p. 74 ed. Baron, cited below n. 111. 
classical Latin texts like Cicero's speeches and his rhetorical treatise De inventione had been translated ${ }^{96}$ but Aristotle's Nicomachean Ethics as well. ${ }^{97}$ Bruni did not avail himself of the vernacular in order to make his translations available to a wider readership, rather he used the same language as the earliest translator of the Politics. Botley ${ }^{98}$ observed that "all of Bruni's Aristotelian translations were re-translations of texts available in medieval versions." Bruni's goal was to replace these translations, to get rid of the obscurity he found in them ${ }^{99}$ and to enhance the understanding (cognitio) ${ }^{100}$ of Aristotle's works. Bruni's objections against the medieval translator were not without precedence. Already Jerome had pointed out that what is translated ad verbum not only sounds absurd ${ }^{101}$ but obscures the sense as well. ${ }^{102}$ In his translations he did not compromise with regard to sense, even if some-

96 Translated by Brunetto Latini (c. 1220-1294), incomplete, s. Witt 2000, p. $183-185$.

97 Translated by Taddeo Alderotti (1210-1295) into Tuscan, from the Latin translation by Herman the German, s. Witt 2000, p. 180.

98 Botley 2004, p. 41.

99 Bruni, Dialogus p. 58 ed. Garin. Cf. Bruni's charge that William's translation did not clarify, but obscured the understanding of the text, $D e$ Interpretatione [44] p. 120; Bruni, Praemissio Politicorum p. 74 ed. Baron (per enigmata), translated in: Griffiths, Hankins, Thompson 1987, II 7 :VI, p. 162-164. Related is the charge that the previous translation of the Nicomachean Ethics was "confused" (qua nihil est turbatius): Bruni, Praemissio Ethicorm p. 77 ed. Baron, translated by Griffiths, Hankins, Thompson 1987, IV 2, p. 213. In Vita Aristotelis, p. 46 ed. Baron, Bruni blames the translator for the perception of readers who consider Aristotle to be intricatum quemdam et obscurum et inconcinnum.

100 See below p. $58 \mathrm{f}$. He accuses William of accomplishing the opposite: Hoc non est interpretari, sed confundere, nec lucem rebus, sed caliginem adhibere, De Interpretatione [44] p. 120. This is almost a topos since Coluccio Salutati in his letter to Pietro Corsini tried in his revision of the translation of Plutarch's De ira by Simon Atumano, opusculum illud de sue translationis obscuritate planiore dicendi genere in lucem intelligentie revocare, Epistolario, book VIII, no. 23, vol. II, p. 483 ed. Novati. $\mathrm{He}$ contrasts its obscuritas with not only the venustas, dulcedo, ornatus, but as well the perspicuitas of translations by Cicero, Jerome, Ambrosius, Boethius, and others (p. 482).

101 Si ad uerbum interpretor, absurde resonant, ep. 57.5.7, repeated 11.4.

102 Ex alia in aliam linguam ad uerbum expressa translatio sensus operit, ep. 57.6.1. 
thing about the words might be missing. ${ }^{103}$ Later John the Scot (c. 815-877), in his introduction to the translation of Dionysius Areopagita, entertained the possibility that his translation could be judged obscuram minusque apertam and expressed fear that he has committed the fault of the faithful translator (ne forte culpam fidi interpretis incurram) ${ }^{104}$ Even John the Scot who himself followed the method of the faithful translation is aware of possible problems this approach causes for a reader. John the Scot echoed Boethius who in his commentary of Porphyry's Isagogē had expressed his concern that he committed the fault of the faithful translator (ne subierim fidi interpretis culpam) by translating verbum $e$ verbo. ${ }^{105}$ As noted before (p. 11), Cicero in his translation wanted to be faithful to the sense of the source (sententiis isdem, De optimo genere oratorum 5.14), not the words.

Bruni wanted to accomplish his goal by using a form of Latin that imitated classical prose, a language that could be called Latin, ${ }^{106}$ freed from the 'barbaric' blunders committed by previous translators. He sought to preserve in his Latin translation the elegance of the Greek philosophical text so that the Greek authors themselves would not be embarrassed to the degree that they would deny that they were the authors of the works translated (see below p. 58 n. 222). In doing so, he played the leading part in the effort to restore the proper use of the classical Latin language and to revive Latin literary culture..$^{107}$

103 Transposui, ut nihil desit ex sensu, cum aliquid desit ex uerbis, ep. 57.6.2.

104 PL vol. 122, col. 1032 C, cited by Schwarz 1944, p. 73.

105 In Isagogen Porphyrii commenta, CSEL vol. 48, 1906, p. 135.

106 At the end of Praemissio Ethicorum Bruni claims that in his translation he for the first time made these books to be Latin whereas before they were not (illud assecutum me puto, ut hos libros nunc primum Latinos fecerim, cum antea non essent): p. 81 ed. Baron, translated by Griffiths, Hankins, Thompson 1987, IV:2, p. 217. This sounds like Balbus' comment on Cicero's Aratea, his translation of Aratus: "they give him so much pleasure because they are Latin", (Aratea) ita me delectant quia Latina sunt, De Natura Deorum II 41 104, s. below n. 189. cf. Coluccio Salutati in his letter to Pietro Corsini, on the revision of a translation of Plutarch's De ira: pro semigreca translatione remitto tibi latinum tractatum, Epistolario, book VIII, no. 23, vol. II, p. 483 ed. Novati.

107 S. Hankins in: Griffiths, Hankins, Thompson 1987, p. 344 n. 6. 
Since Cicero's Latin prose style ${ }^{108}$ was the model to emulate in Bruni's rendering of Aristotle's Politics, Bruni did not share Cicero's intention of introducing in his philosophical writings Greek philosophy in Rome in a living language, the language used by his contemporaries in his country, the vernacular-in this regard Nicole Oresme came closer to Cicero's mission and had understood himself as doing something similar to Cicero. ${ }^{109}$ Bruni's translation was for the benefit of the smaller circle of learned readers ${ }^{10}$ familiar with Latin, ${ }^{111}$ a dead language, and this was intended: it was actually the truly erudite men (homines ingenue eruditi) who had been turned off by the 'barbaric' quality of the old translation of the Nicomachean Ethics. These men embraced his new translation. ${ }^{112}$ On the other hand, in his letter to the Signori of Siena of Nov. 241438 Bruni expected his new translation of the Politics to be not only of the greatest usefulness to rulers of republics, but hoped that an opportunity would be created for the citizens to read it. ${ }^{113}$ Furthermore, if the use of

108 S. Hankins in Griffiths, Hankins, Thompson 1987, p. $199 \mathrm{f}$. In this "first Ciceronianism", however, humanists did not yet follow slavishly Cicero's use of vocabulary or syntax, Witt 2000, p. 403.-As Bruni's model for judging the medieval translations serves as well Boethius. After listing some of the merely transliterated Greek words in the earlier translation of the Nicomachean Ethics, Bruni adds: Haec a Boëthio longe absunt, viro in utraque lingua docto et eleganti, letter to F. Picolpassi of Oct. 15 1435, book 7.4 (p. 127 f. Luiso), no 3, p. 191 ed. Birkenmajer.

109 S. Gregorio 2008, p. 116.

110 Cf. Bruni in his letter to Humphrey, Duke of Gloucester, of 1437, translated by Griffiths, Hankins, Thompson 1987, II 7: 2, p. 157: the Duke has compelled him "to do what you thought would be of benefit to men of learning", referring to the completion of his translation of the Politics.

111 Bruni, Praemissio Politicorum p. 74 ed. Baron, translated by Griffiths, Hankins, Thompson 1987, II 7:VI, p. 163: he wanted to give to those qui Latina utuntur lingua, ignaris Graecarum litterarum the opportunity to read the text without the obscurities of the old translation.

112 Bruni, Praemissio Politicorum p. 74 ed. Baron, translated in: Griffiths, Hankins, Thompson 1987, II 7:VI, p. 163.

113 no. 20 p. 143 ed. Baron, book 8.7 (p. 140 f. Luiso), translated by Griffiths, Hankins, Thompson 1987, II 7:VIII, p. 165 f. In the Praemissio Politicorum p. 74 ed. Baron, translated in: Griffiths, Hankins, Thompson 
Latin limited access to his translation in Italy, it allowed it on the other hand to be of more than regional importance, it allowed this translation to be studied outside of Italy, so in England ${ }^{114}$ or Spain, ${ }^{115}$ and to reach "the most remote shores of the earth" (extremas terrarum oras) $)^{116}$ Latin was after all not only the language of philosophical discourse during the Renaissance but the main literary language of the entire West.

Bruni's task was easier than that of Cicero or Nicole Oresme who had to forge a terminology for the subject matter of the texts they translated. As translator, Bruni did not need to take over Greek words to convey ideas which otherwise could not be expressed in Latin. In the Latin of Cicero, Bruni found a language perfectly suited for his objective because Cicero had expanded the use of Latin to include philosophical terminology and a vocabulary for the ethical and political issues addressed by Aristotle. In his treatise Cicero Novus (1415) Bruni credited Cicero with having been the first to treat philosophy in Rome and adding words to the Latin language which allowed one "to express the findings and controversies of the philosophers more clearly and easily." ${ }^{\text {117 }}$ Bruni who was well versed in the Latin of Cicero-Alfonso of Cartagena

\footnotetext{
1987, II $7: \mathrm{VI}$, p. 163 , he refers to civibus meis as the readers who would benefit from the opportunity to read the text without the obscurities of the old translation. Is this an audience described after Cicero who in De Finibus I 3.7 wrote: si plane sic verterem Platonem aut Aristotelem, ut verterunt nostri poetae fabulas, male, credo, mererer de meis civibus, si ad eorum cognitionem divina illa ingenia transferrem. He considers the benefit his translation would have for the citizens.

114 By Humphrey, Duke of Gloucester, see Bruni's letter to him of March 12 1433, no. 18 p. 138-140 ed. Baron, book 6.14 (p. 122 f. Luiso), translated by Griffiths, Hankins, Thompson 1987, II 7:I, p. 154 f., and Bruni's letter of 1437 , translated by Griffiths, Hankins, Thompson 1987, II 7:II, p. $156 \mathrm{f}$.
}

115 By the king of Aragon, cf. Bruni's letter of March 4 1441, book 9.2 (p. 148 f. Luiso); translated by Griffiths, Hankins, Thompson 1987, II 7: IX, p. 166-168.

116 Cf. his letter to F. Picolpassi of Oct. 15 1435, book 7.4 (p. 127 f. Luiso), no 3, p. 187 ed. Birkenmajer.

117 Translated by Griffiths, Hankins, Thompson 1987, III 2, p. 187. Cf. Bruni, Dialogus p. 54 ed. Garin. 
called him "novellus Cicero", 118 and Antonio da Rho and Erasmus "alter Cicero" ${ }^{119}$ - could simply make use of what was available.

\section{BRUNI'S TRANSLATION OF ARISTOTLE'S POLITICS}

The end of Aristotle's Nicomachean Ethics ${ }^{120}$ contains a transition to the Politics. From a systematic point of view, Aristotle wanted the Nicomachean Ethics to be understood as a philosophical treatise that preceded the Politics. Bruni when translating these two works of Aristotle follows the same order ${ }^{121}$ - the translation of the Nicomachean Ethics was completed by $1417^{122}$ and that of the Politics dates from $1437^{123}$

Bruni justified his translation of the Nicomachean Ethics in his treatise De Interpretatione recta. ${ }^{124}$ In this work he defended himself against critics who had charged him with being too harsh in his

118 Liber Alphonsi episcopi Burgensis, no. 2, p. 164 ed. Birkenmajer. Bruni refers to this judgment in his letter to F. Picolpassi of 1438 , book 8.2 (p. 137 f. Luiso), no 5 p. 195 ed. Birkenmajer.

119 Antonio da Rho, s. Seigel 1968, p. 113 n. 31; Erasmus s. Th. Zielinski, Cicero im Wandel der Jahrhunderte, Darmstadt 51967, 345 n. to p. 181.

120 Nicomachean Ethics X 101181 b15 ff.

121 It should be noted that for Bruni the branch of philosophy that deals with action consists of three parts, ethics, household management, and politics: Praefatio Oeconomicorum Aristotelis (of 1420), no. 10, p. 120-121 ed. Baron, translated by Griffiths, Hankins, Thompson 1987, VII 2, p. $305 \mathrm{f}$. This partition of philosophy is older, it was already used by Aelius Aristides in Stobaios Eklogai II $14726 \mathrm{f}$. Wachsmuth; Boethius, In Isagogen Porphyrii commenta I 3, CSEL 48, 1906, p. 7-9, then by Cassiodorus and Isidore of Seville, s. Flüeler 1992, vol. 1, p. 2 f.

122 Botley 2004, p. 42.

123 The great number of letters and dedications proves how important Bruni considered this translation to be, Baron 1928, p. XXI f.

124 According to Baron 1928, p. 165 f., it was written at the beginning or in the middle of the 1420 ; Viti 2004, p. $54 \mathrm{f}$.; $68 \mathrm{f}$. follows this view. P. Thiermann, Die Orationes Homeri des Leonardo Bruni Aretino, Leiden 1993, 119-125, argued that the edition of the Politics predated De Interpretatione, cf. Botley 2004, p. 42 n. 173. However, the contradiction between some of the principles espoused in De Interpretatione and the 
criticism of earlier translators of this work..$^{125}$ Bruni responded that he had reacted so severely because he felt pain and anger when he saw books that had been composed with so much elegance smeared with dirt in Latin. ${ }^{126}$ In order to demonstrate that not only orators but philosophers as well wrote in an elegant style ${ }^{127}$ he cites, in translation, passages from Plato's Phaedrus and Aristotle's Nicomachean Ethics and Politics. ${ }^{128} \mathrm{He}$ then proceeds to present examples of blunders found in a previous translation of an Aristotelian text. Given that one objective of this treatise is to defend himself against the charge of severely criticizing a previous translation of the Nicomachean Ethics it is understandable that he focuses now on the translation of a different work, the Politics. This strengthens his case because the blunders are not limited to the previous translation of the Nicomachean Ethics but are also found in that of the Politics, which Bruni assumes to be the work of the same translator (idem traductor) as that of

practice of Bruni's translation seems more difficult to accept if $D e I n$ terpretatione and the translation of the Politics fall almost in the same time.

125 "Bruni's own behavior was not exactly diplomatic," Hankins 2003, p. 194. Battista de' Giudici († 1484) reacts to Bruni's introduction, stating that the combination of eloquence and arrogance in Bruni had the effect that he could hardly read his work without revulsion, vix eius scripta sine stomacho legere possum, in Grabmann 1926, p. 443 n. 9.

126 Bruni, De Interpretatione [2] p. 74: Ego autem fateor me paulo vehementiorem in reprehendendo fuisse, sed accidit indignatione animi, quod, cum viderem eos libros in greco plenos elegantie, plenos suavitatis, plenos inestimabilis cuiusdam decoris, dolebam profecto mecum ipse atque angebar tanta traductionis fece coinquinatos ac deturpatos eosdem libros in latino videre. The same 'fecal' expression is found as well in Bruni's letter to F. Picolpassi of Oct. 15 1435, book 7.4 (p. 127 f. Luiso), no 3, p. 192 ed. Birkenmajer. Did Vettori cite Bruni when in the preface to his commentary of Arist. Rhetoric he remarked how much disgust (fastidium) he experienced when he used William's translation in order to find out si ex faece illa sinceri aliquid purique depromi, atque erui coniuectura possit (cited by Schneider 1971, p. 74)?

127 For elegantia s. De Interpretatione [2] p. 74; [6] p. 78; [32] p. 104; [36] p. 112; suavitas [2] p.74; [45] p. 120; decus [2] p. 74; maiestas [13] p. 84; [16] p. 86; [29] 102.

128 De Interpretatione [19] p. 88-[28] p. 100. 
the Nicomachean Ethics ${ }^{129}$-falsely. ${ }^{130}$ Only at the end of this treatise, before justifying again the tone of his criticism of the earlier translation of the Nicomachean Ethics, does he take issue with the earlier translator who in his translation of the Nicomachean Ethics left epiichiam transliterated from Greek. ${ }^{131}$

In this treatise $D e$ Interpreatione ${ }^{132}$ he demands a thorough command of both languages from a translator ${ }_{,}^{133}$ first of the foreign language of the text he translates ([6] p. 78) in order to recognize the learned allusions and in particular poetical quotations which are cited out of context and don't fit into the new context according to the rules of syntax. Bruni lived up to this expectation: The progress in Bruni's translation of the Politics over that of William is a better grasp of the realia. The Cretan poet Epimenides who is in William's translation Epimenides autem okres ${ }^{134}$ - he certainly

129 Bruni, De Interpretatione [31] p. 102: Aristoteles in libro Politicorum quarto (utriusque enim operis idem fuit traductor, nec refert, ex illo vel hoc exempla sumantur) ...

130 The translator was Robert Grosseteste, s. Viti 2004, p. 187 f. On the other hand, in his letter to F. Picolpassi of Oct. 15 1435, book 7.4 (p. $127 \mathrm{f}$. Luiso), no 3, p. 192 ed. Birkenmajer, Bruni distinguishes between an interpretatio vetus of Aristotle's Ethics which is a translation from an Arabic source and an interpretatio novior a Britanno quodam traducta.Grosseteste's translation was later revised. It is disputed whether William or some anonymous translator of the $13^{\text {th }}$ cent. undertook this task, cf. Vanhamel 1989, 337-339.

131 De Interpretatione [44] p. 120 (cited above p. 20 n. 52). Cf. Bruni's letter to F. Picolpassi of Oct. 15 1435, book 7.4 (p. 127 f. Luiso), in Birkenmajer no 3, p. 187; and book 8.2 (p. 137 f. Luiso), in Birkenmajer no 5, p. 208 (epiicheam).

132 Some of the views expressed here are mentioned in Bruni's letter to Humphrey, Duke of Gloucester, of March 12 1433, no. 18, p. 138-140 ed. Baron, book 6.169 (p.122 f. Luiso), translated by Griffiths, Hankins, Thompson 1987, II 7:1, p. $154 \mathrm{f}$.

133 De Interpretatione [5] p. 76. Already Roger Bacon had demanded this: oportet quod translator sciat linguam a qua transfert, et linguam, in quam transfert, in: J.S. Brewer, Fr. Rogeri Bacon, Compendium Studii Philosophiae, London 1859 (repr. 1965), cap. VIII, p. 471. See R. Lemay, "Roger Bacon's Attitude Toward the Latin Translations and Translators of the Twelfth and Thirteenth Centuries", in: J. Hackett (ed.), Roger Bacon and the Sciences. Commemorative Essays, Leiden 1997, p. 25-47.

134 William p. 5.5 ed. Susemihl, translation of Arist. Politics I $21252 \mathrm{~b} 14 \mathrm{f}$. 
did not understand okres himself-is in Bruni's version Epimenides vero cretensis $^{135}$, Epimenides from Crete, a reading based on identi-

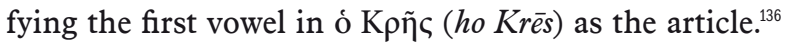

With his expectations for the qualification of a translator, Bruni goes beyond the requirement of linguistic competence, rather he demands from the translator familiarity with the literature in that language, including poetry, so that he understands all facets of the literary quality of the text to be translated. The translator has to know the literary culture of the language from which he translates. Here Bruni inserts a few examples of quotations from Homer found in Aristotle's Politics. ${ }^{137}$

With regard to proprietas or significatio verbi that is so important for medieval translators Bruni introduces in a letter ${ }^{138}$ a distinction unknown to them, that is ex vi ipsius verbi and ex usu. Vis is the meaning of a word in its etymological sense whereas usus takes into account the testimonium scriptorium; in De Interpretatione he uses for the latter consuetudo, the customary meaning. ${ }^{139}$ This affects political terminology on which Bruni's judgment is particularly strict. He demands that the translator masters the target language well enough to distinguish terms and not to use e.g. urbs instead of civitas. ${ }^{140}$ This brief remark is in fact a reckoning with the Medieval

135 Bruni ed. Paris 1526 f. $2^{\mathrm{r}}$.

136 Errors in translations caused because of reading two (or three) words as one are found as well in the Translatio vetus of the Rhetoric, cf. Schneider 1971, p. 24; failure to recognize a name ibid. p. 27; wrong separation of Greek words ibid. p. 23 f. For Bruni's conjectures and corrections of the Greek text cf. Hankins in: Griffiths, Hankins, Thompson 1987, p. 13.

137 Bruni, De Interpretatione [9] p. 8o, refering to Arist. Politics III $161287 \mathrm{~b} 14$ and $51278 \mathrm{a} 37$. In his treatise De Studiis et litteris of 1424 , Bruni recommends to Battista Malatesta of Montefeltro, a young woman who is the recipient of this letter, reading the poets since all distinguished men had a knowledge of them, and refers first to Aristotle who very often cited lines of Homer, Hesiod, Pindar, Euripides and others, p. 13 f.; 18 ed. Baron, translated by Griffiths, Hankins, Thompson 1987, V:2, p. 246; 249.

138 Letter to F. Picolpassi of 1438 , book 8.2 (p. 137 f. Luiso), no 5, p. 202 ed. Birkenmajer.

139 De Interpretatione [11] p. 82; [35] p. 110. This was already Cicero's term, s. above p. 11 n. 9 ; p. 17 n. 42.

140 Ibid. [11] p. 82: Deinde linguam eam, ad quam traducere vult, sic ... norit, ne ... urbem pro civitate dicat. 
tradition in which Greek politeia was translated by urbanitas, e.g. by Robert Grosseteste, Albertus Magnus and Thomas of Aquinas. ${ }^{141}$

Related is a distinction between verba and sententia verborum which is roughly equivalent to the literary sense of a word and the idiomatic meaning it receives in a certain context. ${ }^{142}$ The latter includes attention a translator has to give to the sense or meaning of an argument. It was Cicero who in De optimo genere oratorum 5.14, when explaining the principles he was to follow in his translation, rejected a method of verbum pro verbo like an interpres but remained faithful to the ideas (sententiis isdem) and the form in which they were expressed like an orator. Jerome had followed this approach since his youth (s. above p. 23 n. 70). Already Coluccio Salutati and Bruni's teacher of Greek, Chrysoloras (ca. 1350-1414), had advocated the ad sententiam translation. ${ }^{143}$ Chrysoloras was quite specific when he required that translators who reproduce the sense of the source follow the principle that the propriety of the Greek text in no way be sacrificed as if it were a law. ${ }^{144}$

141 S. Minio Paluello 1972, p. 290-296-the alternative was civilitas, cf. Bertelloni 2007.

142 Bruni, De Interpretatione [7] p. 78: cum aliud verba, aliud sententia verborum significet. Among the examples he cites is desiderati milites which in this context means that the soldiers died (periere).

143 Coluccio Salutati in his letter to Pietro Corsini: being annoyed with the quality of a previous translation of Plutarch's De ira he aspired to remove obscurity. And while this would not allow to read Plutarch literally, nihil tamen quo ad sententiam nos lateret, Epistolario, book VIII, no. 23, vol. II, p. 483 ed. Novati; cf. Hankins 1991, vol.1, p. 44 f.; id. 2003, p. 177 with n. $1 ; 2007$, p. 335 f. At the beginning of the $14^{\text {th }}$ cent., translators of Latin texts into the vernacular had faced this problem, such as Bartolomeo da San Concordio who translated Sallust's Catilinae coniuratio around 1302 in Florence and stated in the preface that Latin and the vernacular do not correspond completely and that it was, therefore, "appropriate to depart somewhat from the words, in order to express the thought and to be able to speak more clearly and without subtlety" ("si conviene uscire alquanto dele parole per isponere la sentenzia e per potere parlare più chiaro e aperto"), cited by Witt, 2000, p. 187 with n. 53 (Witt's translation).

144 Cf. the report by Cincius Romanus cited by Keßler 1995, p. XI n. 16 Sed ad sententiam transferre opus esse aiebat hoc pacto, ut ii qui huiusmodi rebus operam darent, legem sibi indicerent, ut nullo modo proprietas greca mutaretur. 
Bruni stresses in De Interpretatione the difficulty of the task of translating. It is in this context that he expresses his high opinion of the style of Aristotle and Plato. He argues that both employed the most elegant style of writing, filled with sayings of the old poets, orators, and historians. It is important to note that in the judgment on the literary quality of the Greek philosophers, Aristotle and Plato are not only referred to in one breath but that Aristotle is mentioned first and his name is not simply attached, as a kind of afterthought, to that of Plato. ${ }^{145}$ However, Bruni goes beyond this in making the point that individual authors have their own specific style which the translation must reproduce-Bruni actually argues that the translator is swept away into the style of his source by its own force ${ }^{146}$ and cannot do justice to the sense of the text unless he follows its stylistic structure. ${ }^{147}$ Furthermore, Bruni demands that the translator does not, because of his insufficient command of the language into which he translates, keep from his source certain terms in Greek ${ }^{148} \mathrm{He}$ takes it as a sign of the greatest ignorance to leave Greek words untranslated since the Latin language possesses the most fitting expressions.

145 Bruni, De Interpretatione [6] p. 78: presertim cum Aristoteles ipse et Plato summi, ut ita dixerim, magistri litterarum fuerint ac usi sint elegantissimo scribendi genere veterum poetarum et oratorum et historicorum dictis sententiisque referto, et incidant frequenter tropi figureque loquendi, que aliud ex verbis, aliud ex consuetudine preiudicata significant.

146 Ibid. [14] p. 86 Rapitur enim vi ipsa in genus dicendi illius de quo transfert. Arist. Politics VIII 7 1342b9 ff. expresses a similar idea when he told the anecdote about Philoxenos who wanted to compose a dithyrambus in the Dorian mode but "by the very nature (of this genre) fell

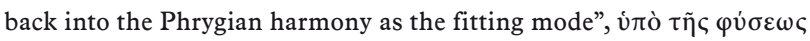

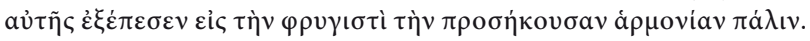

147 Bruni, De Interpretatione [14] p. 84-86.

148 Bruni makes this requirement in the case of ut verbum verbo reddendum fuerit ibid. [11] p. 82. He, therefore, does not reject this practice of translation per se but seems to indicate that this method is particularly prone to transliteration, cf. ibid. [34] p. 108, see above p. 19. 


\section{THE POLITICAL TERMINOLOGY IN BRUNI'S TRANSLATION- A NEW HUMANIST CONCEPT OF RES PUBLICA?}

Bruni claims that nothing has been said in Greek that could not be said in Latin. ${ }^{149}$ In particular Bruni criticizes that at many places the previous translator of the Politics leaves the Greek word for constitution politia ${ }^{150}$ instead of using res publica and that he inserted unnecessarily the terms for individual constitutions oligarchia, democratia and aristocratia instead of using e.g. popularis status for democracy ${ }^{151} \mathrm{He}$ claims that such a translation looks half-Greek ${ }^{152}$-if Bruni had known William's translation of

149 Cf. already Cic. De Finibus I 3 10: the Latin language is locupletior, cf. above p. 27 n. 89 .

150 Politia is used as well by Robert Grosseteste, Albertus Magnus, Thomas of Aquinas and Tolomeo di Lucca, s. Minio-Paluello 1972, p. 290-294.

151 Bruni, De Interpretatione [43] p. 120: Quid de verbis in greco relictis dicam, que tam multa sunt, ut semigreca quedam eius interpretatio videatur? Atqui nihil grece dictum est, quod latine dici non possit! ... Enim vero, quorum optima habemus vocabula, ea in greco relinquere ignorantissimum est. Quid enim tu mihi 'politiam' relinquis in Greco, cum possis et debeas latino verbo 'rem publicam' dicere? Cur tu mihi 'oligarchiam' et 'democratiam' et 'aristocratiam' mille locis inculcas et aures legentium insuasissimis ignotissimisque nominibus offendis, cum illorum omnium optima et usitatisssima vocabula in latino habeamus? Latini enim nostri 'paucorum potentiam' et 'popularem statum' et 'optimorum gubernationem' dixerunt. In his letter to F. Picolpassi of 1438, book 8.2 (p. 137 f. Luiso), no 5, p. 208 ed. Birkenmajer, Bruni makes the same points regarding the transliteration of

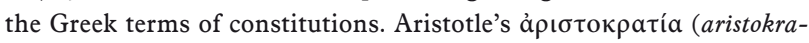
tia) Bruni translated as well as optimas (status) (ed. 1469 f. $107^{\mathrm{V}}=\mathrm{II}$ 9 1270b16), optimatium gubernatio (ibid. $116^{\mathrm{V}} / 117^{\mathrm{r}}=$ III 7 1279a35) or shorter optimates (ibid. $110^{\mathrm{r}}=$ II 11 1273a21; ibid. $132^{\mathrm{v}}=$ IV 8 1293b36). It should be noted that paucorum potestas and popularis status were already used by Thomas of Aquinas in his commentary on Politics II 6 1265b33-41, cf. Minio-Paluello 1972, p. 292-here William (p. 92.8 ed. Susemihl) wrote oligarchia and democratia.

152 Cf. Bruni's letter to F. Picolpassi of Oct. 15 1435, book 7.4 (p. 12 f. Luiso), no 3, p. 192 ed. Birkenmajer, and his letter to Picolpassi of 1438 , book 8.2 (p. 137 f. Luiso), no 5, p. 202 ed. Birkenmajer. In Praemissio 
Aristotle's Poetics he might have chosen as an example intragodotatissimus for Aristotle's ả $\rho \alpha \gamma \omega \delta$ dó $\tau \alpha \tau{ }^{153}{ }^{153}$ Bruni's own standards of a correct translation is that it 'matches' the Greek..$^{154}$

It is difficult to determine how Bruni's theoretical and programmatic principles of translating were actually implemented in his own translations of the Politics since there exists no modern critical edition of Bruni's translation. The printed editions, starting with the first edition of 1469 (reproductions below pp. 60-63) and early prints of the $15^{\text {th }}$ cent. I inspected, show a great number of discrepancies that actually affect political terminology. ${ }^{155}$ Still, in spite of these problems, one can get a fair impression of his technique of translating.

Bruni takes the principle of avoiding transliterations generally quite seriously: William's yconomia $a^{156}$ as translation of Aristotle's oikкоvонia (oikonomia) becomes disciplina rei familiaris ${ }^{157}$

Ethicorum p. 77 ed. Baron, he applies this criticism to the translator: Ita semigraecus quidam et semilatinus fit, in utraque deficiens lingua, in neutra integer, translated by Griffiths, Hankins, Thompson IV:2, p. 213. Battista de' Giudici protested against this characterization of the scholastic translation of Nicomachean Ethics, s. Grabmann 1926, p. 444 n. 12, s. below p. 65 f.-Colucci Salutati in his letter to Pietro Corsini characterizes as semigreca the translation of Plutarch's De ira by Simon Attumano, in Epistolario, book VIII, no. 23, vol. II, p. 483 ed. Novati.

153 Minio-Paluello 1972, 51. Ibid. he quotes William's rendering of poein for

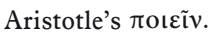

154 S. Bruni's letter to F. Picolpassi of Oct. 15 1435, book 7.4 (p. 127 f. Luiso), no 3, p. 189 ed. Birkenmajer: interpretatio autem omnis recta si Graeco respondet, vitiosa, si non respondet. Boethius' translations meet this standard: Textus est nitidus et planus et Graeco respondens, cf. ibid. p. 191.

$155 \mathrm{Cf}$. III $151286 \mathrm{~b} 17$, the transition from tyrannical regimes to democracy ( $\dot{\varepsilon} \kappa$

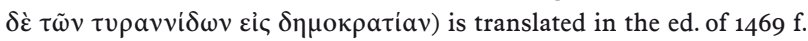
$124^{\mathrm{v}}$ Ex tyrannis rursus ad plebem (same translation in ed. Paris 1515 f. $43^{\mathrm{v}}$ and $1526 \mathrm{f} .54^{\mathrm{r}}$ ), but in the ed. Paris $1511 \mathrm{f} .50^{\mathrm{r}}$ Ex tyrannide rursus ad popularem potentiam. Popularis status is the usual term for democracy, but just as Bruni can use nobiles for aristocracy (s. above n. 151) so plebs would be fitting for democracy. Aristotle can use demos for democracy, and Bruni translates demos Politics III $41277 \mathrm{~b} 3$ as populus, ed. Paris $1526 \mathrm{f.} 44^{\mathrm{v}}$.

156 p. 12.3 ed. Susemihl, translation of Politics I 31253 b12.

157 Politics I 3 1253b12, Bruni ed. 1469 f. 90 ${ }^{\mathrm{r}}$, cf. Praefatio Oeconomicorum Aristotelis (of 1420), no.10, p. 121 ed. Baron, translated by Griffiths, Hankins, Thompson 1987, VII:2, p. 305-306. 
or res domestica. ${ }^{158}$ William's translation had aimed at giving the reader an impression even of the original semantic meaning or the etymology of the Greek word translated (see above p.22). His practice of coining hybrid words like animalifaga, fructifaga or

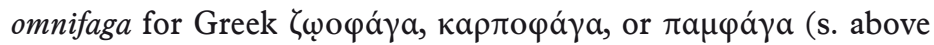
p. 21) is avoided by Bruni when he translates or rather paraphrases these adjectives with subordinate clauses cum alie vivis animalibus. alie fructibus. alie cunctis pascuntur (ed. 1469 p. $93^{\mathrm{r}}$ ). And William's aequityrannum ${ }^{159}$ as translation of iootúpavvov (isotyrannon) is rendered by Bruni with tyrannidi parem. ${ }^{160}$ Bruni is not bound by the principle of verbum pro verbo.

It was mentioned above (p. 22 f.) that Aristotle's $\sigma u ́ v \tau \alpha \xi ı \varsigma$ (syntaxis) became in William's translation coordinatio (p.91.26 ed. Susemihl) which provides the accurate semantic equivalent for both parts of the Greek word whereas Bruni translated it as constitutio (ed. 1469 p. $102^{\mathrm{v}}$ ). In the passage under consideration (II 6 1265b26) Aristotle classifies the specific 'constitutional' form of Plato's Laws. Bruni's choice constitutio has a Ciceronian ring to it, ${ }^{161}$ and would eventually become a crucial political term. ${ }^{162}$

158 Politics I 3 1253b2, Bruni ed. 1469 f. $90^{\mathrm{r}}$.

159 II 91270 ob13 f.; p. 123.3 ed. Susemihl.

160 Bruni ed. 1469 f. $107^{\mathrm{v}}$.

161 Cf. De Republica I 45.69 in hac iuncta moderateque permixta constitutione rei publicae, cf. 46.70 ; II 21.37. Bruni did not know this text, but he knew De Legibus III 5.12 Quae res cum sapientissime moderatissimeque constituta esset a maioribus nostris. The preceding sentence Nam sic habetote, magistratibus iisque qui praesint contineri rem publicam, et ex eorum compositione quod cuiusque rei publicae genus sit intellegi makes clear that constituta refers to res publica, the idea expressed represents very much Aristotle's position at Politics III 6 1278b8-10: "a constitution is the order of the offices and in particular of the office that rules over all (or "over everything"; embarrassing B. Jowett's translation: “ ... the arrangement of magistracies in a state, especially of the highest of all"),

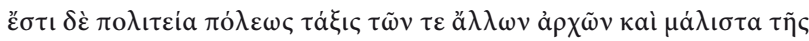

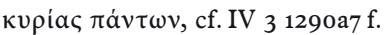

162 H. Conring in his commentary on Lampadius' De republica RomanoGermanica gives four definitions of respublica, the second is: ordo sive constitutio civilis societatis, cum ratione ceterarum potestatum, tum praecipue ratione eius, quae omnium est summa vel domina (Opera 2.22) which echoes Arist. Politics III 6 1278b8-10 (s. previous n.). Conring translates 
Bruni who had objected to transliterations such as politia for

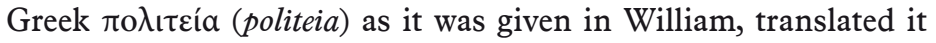
by res publica as he had demanded in De Interpretatione. In doing so, Bruni followed Cicero, who took over the title of the Platonic

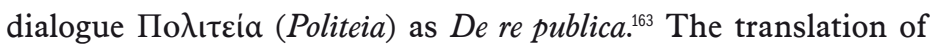

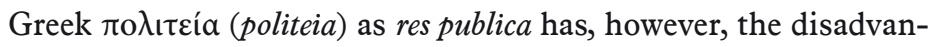

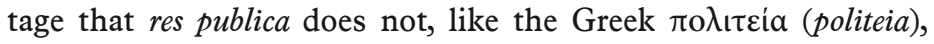

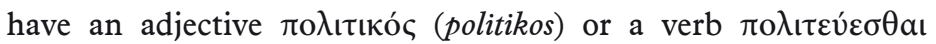
(politeuesthai) as derivatives from the stem these terms share with polis and politēs. The etymological connection of Greek polis, politēs, politeia, politikos is sacrificed both by William and Bruni. By William it is given up when he translated on the one hand polis by civitas $^{164}$ and polites by civis, but left on the other hand politeia and often politikos untranslated. This is by no means an obvious choice since medieval translations had rendered politeia by civilitas $^{165}$ and William himself chose at times civilis as translation of politikos (s. above p.19). Bruni agrees with William in translating polis by civitas (when William used this Latin word instead of the transliterated politeia, see above p. 19) and politês by civis and stays within this etymological pattern by choosing civilis as translation of the adjective politikos ${ }^{166}$ as it had been done by Cicero. ${ }^{167}$ Aristotle's statement

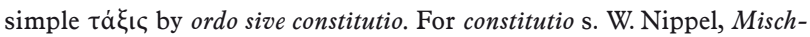
verfassungstheorie und Verfassungsrealität in Antike und früher Neuzeit, Stuttgart 1980, 11 f. with n. 6; s. below p. 49 n. 193.

163 Cf. On Divination II 1.3 his libris adnumerandi sunt sex de re publica, quos tum scripsimus ..., cf. ep. ad Atticum XIII 19.4 nos in VI de re publica libris fecimus; De Legibus II 6.14; at I 5.15 Atticus refers with de optimo rei publicae statu both to Plat. Republic and Cic. De Republica, cf. ep. ad Quintum fratrem III 5.1.

164 For the meaning of civitas in its legal and philosophical sense see Schmidt 1986, p. 305-310.

165 S. Minio-Paluello 1972, p. 285-296.

166 Aristotle's remark about man as zoon politikon by nature (ó öv $\theta \rho \omega \pi \mathrm{\alpha} \varsigma$

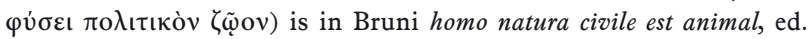
1526 f. $3^{\mathrm{v}}$.

167 At Cic. De Republica III 3.6 illa in optimis studiis et artibus quieta vitae ratio is contrasted with haec civilis, i.e. the life of politics; cf. De Finibus IV 2.5 locum in philosophia, quem civilem recte appellaturi videmur, Graeci $\pi \mathrm{o} \lambda \iota \tau$ เ òv, s. Minio-Paluello 1972, p. $286 \mathrm{f}$. 
in Politics I 2 that "man is by nature an animal destined to live in a polis" was translated by William as homo natura civile animal est (p. $7.6 \mathrm{f}$. ed. Susemihl)-it is translated by Bruni in exactly the same words, with only the auxiliary verb est moved. ${ }^{168}$

The essential difference between the two translators consists in their rendering of politeia and in their translation, and under-

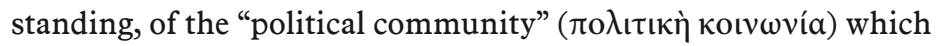
the polis is according to Aristotle Politics I 1. For William it is communicatio politica (s. above p. 16 n. 39). Communicatio is not a poor choice as one can see from Cicero whose communicatio sermonis (ep. ad Atticum I 17.6) and communicatio utilitatum (De Finibus V 23.65) cover the areas of human social interaction addressed by Aristotle in Politics I $21253 \mathrm{a} 14 \mathrm{ff}$. and III $61278 \mathrm{~b} 16 \mathrm{ff}$. respectively. However, William's selection of this term seems rather influenced by the translation in the New Testament of communicatio for koinōnia by Jerome. ${ }^{169}$ Bruni in turn chose as translation of "political community" societas civilis which draws on the tradition of Cicero $^{170}$ and Roman Law in which societas was a partnership entered for the purpose of some business. ${ }^{171}$ Societas civilis ${ }^{172}$ renders this aspect of Aristotelian koinōnia quite adequately since it is an association formed for the purpose of a certain common good. ${ }^{173}$ Bruni's rendering of politeia as respublica offered to the reader some sort of equivalent of the Aristotelian concept. Every reader could associate with res publica an idea which the untranslated Greek word politeia did not provide.

168 ed. 1526 f. $3^{\mathrm{v}}$ homo natura civile est animal. Dante had rendered this remark as l'uomo è animale civile, cited by Rubinstein (1987) 2004, p. 323 n. 40.

169 S. Schmidt 1986, p. 299 f.

170 Bruni could not know Cic. De Republica I 32.49 quid est enim civitas nisi iuris societas civium? However, he knew VI 13 concilia coetusque hominum iure sociati, quae civitates appellantur, cf. De Legibus I 24.62 civilis societas.

171 S. Schmidt 1986, p. 300 f.

172 See P. Hallberg - B. Wittrock, "From koinonìa politikè to societas civilis: Birth, Disappearance and FirstRenaissance of the Concept," in: P. Wagner (ed.), The Languages of Civil Society, New York - Oxford, 2006, p. 28-51.

173 Cf. Arist. Nicomachean Ethics VIII 11 1160a11-30. 
However, does not Bruni's translation create the wrong impression as if Aristotle in his Politics had written about the Roman state? In De Interpretatione Bruni remarks about the property classes which were assessed every five years: "this property assessment every five years they called 'lustrum'; the magistrates which controlled the assessment were called 'censores'" (Id quinquennium 'lustrum' appellarunt; magistratus vero, qui censui preessent, 'censores' dicti sunt; [39] p. 116). He then proceeds to give the Greek translation of some of these terms, ${ }^{174}$ and adds: "however, this fine translator had not read this, but for 'census' he dreamed up 'honorability', creating by himself a new word which nobody before had used" (sed bonus ille interpres ista non legerat. Verum pro censu 'honorabilitatem' somniavit, novum faciens verbum a se ipso, quod nemo ante posuerat). ${ }^{175}$ The neologism (novum faciens verbum) honorabilitas is due to the fact that William had not read the Latin texts which deal with this issue. ${ }^{176}$

This remark is part of Bruni's criticism of William's translation in which Greek terms were simply transcribed. However, with the terms lustrum and censores the reader is moved into a Roman environment, and this could be an objection against such a translation since it masks the fact that Aristotle wrote about the political conditions of a very different society and state. Following this principle, Bruni would give his translation an artificial, that is a Roman patina, and with his focus on semantic

174 Apud Grecos vero censores dicuntur 'timite' et census 'timima' vocatur.

175 Ibid. [39] p. 116. Bruni translated Tí $\mu \eta \alpha$ (timēma) e.g. Politics IV 13 $1297 \mathrm{~b} 2$ as census, f. $70^{\mathrm{r}}$ ed. Paris 1526.

176 Bruni was referring to Liv. I 44.1-2. The charge that the translator had not read the Latin authors (Cicero, Seneca, Boethius, Lactantius, and Jerome are listed) is found as well in Bruni, Praemissio Ethicorum p. 80 ed. Baron, translated by Griffiths, Hankins, Thompson 1987, IV:2, p. 215. Cicero, Seneca, Lactantius, and Jerome appear in De studiis et litteris as those authors who are most highly regarded because of both their knowledge and their literary qualities-added are on the Greek side Plato, Democritus, and Aristotle, and on the Roman Varro, s. p. 19 ed. Baron, translated by Griffiths, Hankins, Thompson 1987, V:2, p. $250 \mathrm{f}$. In the letter to F. Picolpassi of 1438 , book 8.2 (p. $137 \mathrm{f}$. Luiso), no 5, p. 208 ed. Birkenmajer, the list comprises Jerome, Cicero, Lactantius, Livy, Sallust, and Caesar. 
correctness present not only an interpretatio Latina, but an interpretatio Romana. ${ }^{177} \mathrm{He}$ would absorb the Greek political reality of the classical period and present it as if it were the Roman past. This was probably not felt to be a problem in the $15^{\text {th }}$ century on the neoclassical assumption that Greece and Rome formed a cultural unity. ${ }^{178}$

If the earliest printed editions of Bruni's translation of Aristotle's Politics preserve the text as Bruni wrote it, one could argue that, in his intention of creating a translation that does not read like a translated Greek text, Bruni goes too far because one consequence is his decision to cut out from his translation remarks by Aristotle ${ }^{179}$ which refer to the fact that for concepts he described there did not exist any Greek terms. We find two such remarks at Politics I $21253 \mathrm{~b}-10$ and b $10-111^{180}$ both are not rendered by

177 A.C. Dionisotti, "On the Greek Studies of Robert Grosseteste", in A.C. Dionisotti, A. Grafton, J. Kraye (eds.), The Uses of Greek and Latin. Historical Essays, London 1988 (19-39), p. 34, comments similarly from the perspective of Grosseteste: "Leonardo Bruni's translation of Aristotle into the language and thought-world of Cicero would have seemed to Grosseteste, I think, a betrayal, a failure to face up to the foreignness of the text."

178 Hankins in: Griffiths, Hankins, Thompson 1987, p. 11.

179 Schmidt 1986, p. 315 n. 77 , draws attention to the fact that William (p. 233.11 f. ed. Susemihl) leaves out at Politics III $171287 \mathrm{~b} 38$ the trans-

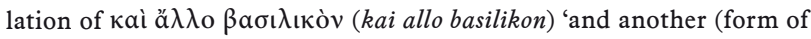
right, Síkatov, dikaion, s. below p. 53 n. 203) appropriate to kingship' and "provided Ptolemy of Lucca ... with a text which had a considerably more republican cast than the Greek original." Given William's principle of verbum e verbo translation, this omission cannot be intentional.

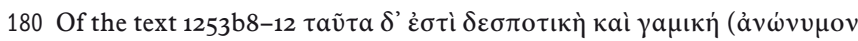

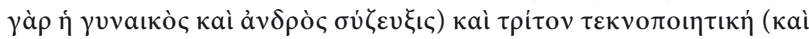

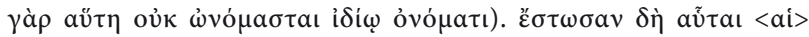

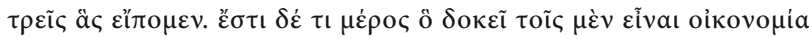
Bruni ed. 1469 f. $90^{\mathrm{r}}$ offers only: hoc est de dominica de coniugiali de paterna disciplina Est insuper quaedam pars quae videtur quibusdam esse

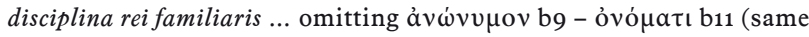
text with all omissions as well in Iuntina $1568, \mathrm{f} .4^{\mathrm{r}}$ ). The edd. of Paris $1511 \mathrm{f.} 4^{\mathrm{v}}$, Paris $1515 \mathrm{f} .4^{\mathrm{v}}$ and $1526 \mathrm{f} .5^{\mathrm{r}}$ have: hoc est de dominica, de coniugiali (nam et ipsa proprio nomine non nominatur) de paterna re familiari sint autem hae tres quas diximus. Est insuper ... Of the 
Bruni, at least in the Strasbourg ed. of $1469 .{ }^{181}$ The reader of his translation does not learn that Aristotle himself introduced concepts which were new in the sense that an appropriate term for them did not exist. In this case in Bruni's translation Aristotle's philosophy is not presented against the background of the Greek knowledge or language as Aristotle wanted it to be understood. It is Aristotle himself who identified his place in the context of Greek philosophical terminology, something Bruni eliminated from the translation and withheld from the reader.

Bruni seems to adhere to a form of linguistic purism to which not even Cicero subscribed to ${ }^{182}$ At On Divination 1.29.60 he writes: "see, what Socrates says in Plato's Politeia" (Vide, quid Socrates in Platonis Politia loquatur). Cicero keeps Politia ${ }^{183}$ and does not insist on res publica which according to Bruni was the proper term to replace the transliterated Greek word politeia. And in his letter Ad Familiares 8.1.4 Cicero has Caelius saying: "Your political books are highly regarded by all" (tui politici libri omnibus

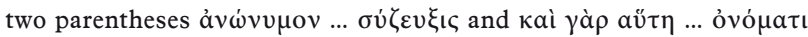
only the second is translated but placed where the first stands in the Greek text.

181 The caveat is that this omission could be due to negligence of the editor of the Strassburg edition of $\mathbf{1 4 6 9}$. However, a common cause for omissions, the occurrence of the same word in close proximity with the effect that the text in-between was skipped, 'haplography' (Baron 1928, p. XXXI), cannot be assumed here. If Bruni left out these words intentionally, this is remarkable in light of his claim that his translation of Arist. Politics "conforms so closely to the Greek that nothing has been left out or added": letter to Humphrey, the Duke of Gloucester, of 1437 translated by Griffiths, Hankins, Thompson 1987, II 7:2, p. 156. According to Alfonso, to reach a rhetorical effect, one had to make additions or leave out words, which is incompatible with scientific knowledge, Liber Alphonsi episcopi Burgensis, no. 2, p. 175 ed. Birkenmajer. However, this omission at Politics I 3 does not serve a rhetorical purpose. For other omissions in the translation of Politics $\mathrm{s}$. Susemihl 1872, p. XXX n. 59. Hankins 1991, vol. I, p. 47, observes that in his translation of Plato's Phaedo Bruni suppresses or alters unsuitable material.

182 Cf. Griffiths, Hankins, Thompson 1987, p. 374 n. 20.

183 As well ibid. II 27.59 Nam si ista sequimur, quod Platonis Politian nuper apud me mures corroserunt, de re publica debui pertimescere ... 
vigent)-Cicero's De Republica are for his contemporaries politici libri-and he himself uses the expression philosophi politici ${ }^{184}$ In his avoidance of Greek terms Bruni did not go so far as to call Aristotle's Politics either De Republica or Libri rerum civilium but Libri Politicorum..$^{185}$

Bruni's purism of the exclusive use of Latin terms in a translation as demanded in De Interpretatione is not observed strictly in his own translation of Aristotle's Politics. While he objected in De Interpretatione to William's transliteration of Greek words, in his own translation of the Politics Bruni keeps Spartan ephoria untranslated and presents simply the transliterated word. ${ }^{186}$ Here and at other times he does not differ a lot from William's rendering (s. below p. 75 n. 269) when he leaves Greek terms. Almost identical are the translations of IV $41292 \mathrm{~b} 8 \ddot{\omega} \sigma \pi \varepsilon \rho \dot{\eta}$

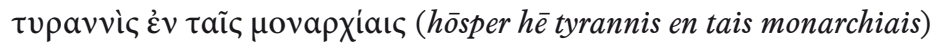
by William (p. 399.2 f. ed. Susemihl) sicut tyrannis in monarchiis and Bruni (ed. $1469131^{\mathrm{r} / \mathrm{v}}$ ) ut enim tyrannus in monarchia, or IV

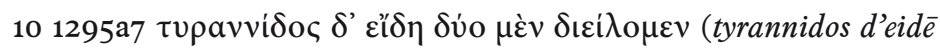
dyo dieilomen) by William (p. 414.11 ed. Susemihl) tyrannidis autem

184 De oratore III 28.109. This expression is somehow mitigated by the fact that it claims to reproduce the Greek wording: a Graecis philosophi politici appellati. In his letters Cicero uses a more casual style which does not have to meet the higher standards of his literary works; here Greek words, even in Greek letters, are interspersed more frequently, e.g. $A d$

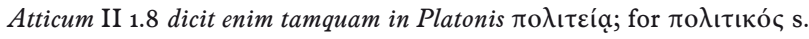
$T L L$, vol. X col. $2534 \mathrm{f}$.

185 Epistula supra translatione (sic) Politicorum Aristotelis. Ad dominum Euenium Papam IV, ed. Baron p. 70, begins: Libros Politicorum ... a me ... traductos; cf. Praemissio Politicorum ed. Baron p. 74.

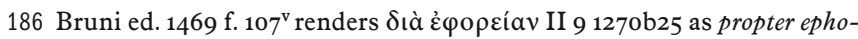
riam-only ephorus is listed in TLL vol. 5, col. 660, but not ephoria or ephoratus (s. below p. 77, append. to II 9 1270b7). The expression tà

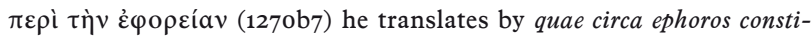
tuta sunt (ed. Paris $1526 \mathrm{f} .31^{\mathrm{r}}$ ); William had written quae circa ephoriam (p. 122.7 f. ed. Susemihl), he differs from Bruni here (and most of the

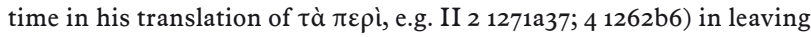
out the verb of the relative clause-as equivalent for the Greek article $\tau \grave{a}(t a)$ that is followed by a preposition William chose the Latin relative pronoun, and strict adherence to the verbum e verbo principle might have precluded him from adding the verb in the relative clause. 
species duas quidem divisimus and Bruni (ed. 1469 p. 134 $4^{\mathrm{r}}$ ) tyrannidis vero species duas ibidem distinximus. One expression is actually identically translated by William and Bruni: III $141285 a 16 \mathrm{f}$. ö $\lambda \lambda \mathrm{o}$

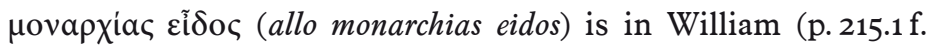
ed. Susemihl) alia monarchiae species, in Bruni ed. 1469 p. $123^{\mathrm{r}}$ alia ... monarchiae species-it should be noted that monarchia is not used in classical Latin. ${ }^{187}$ Close are William's translation of

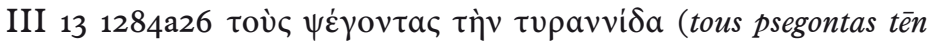
tyrannida) as vituperantes tyrannidem (p. 209.6 f. ed. Susemihl) and Bruni's qui vituperant tyrannidem (ed. 1469 p. $122^{\mathrm{r}}$ ). Of the constitutional terms which William simply transliterated Bruni in De Interpretatione ([43] p.120) lists only oligarchia, democratia and aristocratia, not tyrannis which was after all used in classical Latin $^{188}$-in using words taken over from Greek that had become accepted in Latin Bruni follows Cicero's practice. ${ }^{189}$

In other, admittedly rare, cases, Bruni actually transliterates a Greek term when William tried to find a Latin equivalent, e.g. in the case of the Athenian institution of ostrakismos which becomes in Bruni ostratismus when William had chosen relegatio, relegare..$^{190}$ It is understandable that Bruni did not translate the names of certain musical instruments at Politics VIII 6

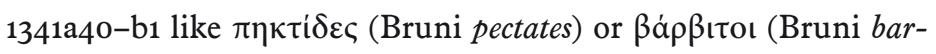

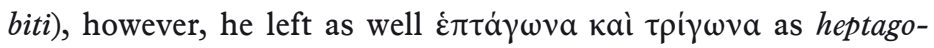
na et trigona. It seems that in De Interpretatione Bruni considered

187 monarchia is used by Tert.; Lact., cf. TLL vol. 8, col. 1400.

188 On tyrannus s. Aug. De civitate Dei II 21 Cum vero iniustus est rex, quem tyrannum more Graeco appellavit (scil. Cicero). For tyrannis s. Liv. XXXV 12.7.

189 According to Cic. Academica I 7.25 f. (cited above p. 17 n. 42) a number of Greek words could be expressed in Latin, however, one uses the Greek term like philosophia, rhetorica, dialectica, following a long established practice. However, Cic. is reluctant to take over Greek words that aren't established yet, cf. On Divination II 53.108 Sed demus tibi istas duas sumptiones (ea quae $\lambda \eta ́ \mu \mu \alpha \tau a$ appellant dialectici, sed nos latine loqui malumus). Similarly Bruni avoids using oeconomica or politica since nos, ut opinor, nostris vocabulis uti magis decet, quam alienis, Praefatio Oeconomicorum Aristotelis (of 1420), no. 10, p. 121 ed. Baron.

190 Bruni ed. 1469 f. $123^{\text {v }}$, translation of Arist. Politics III 131284 a17 ff. (s. below p. 77, appendix); William p. 208.9; 209.2; 211.11 ed. Susemihl. 
such transliterations as the lesser evil when he points out that he would condone transliteration in the case of a few very unusual and remote (admodum peregrinis et reconditis) words if they cannot be easily translated into Latin ([43] p. 120).

On the other hand, in doing so he avoided the impression that Aristotle's Politics was a work that analyzed conditions of the Roman past, and by retaining e.g. tyrannis ${ }^{191}$ he revealed that this constitutional form belongs to the world of the Greeks, and this was the more justified since Aristotle in III 14 had placed the various kinds of tyranny he distinguishes into their specific geographical and historical context. ${ }^{192}$

I referred earlier (p. 26) to the fact that Nicole Oresme introduced into the French language more than 1000 words, among them the word "politique". With his choice of Latin res publi$c a$, which was to replace the transliteration of Greek politeia, Bruni was influential since now res publica, or expanded status or constitutio rei publicae prevailed over Greek politeia. ${ }^{193}$ Ludovicus Valentina replaced in his edition of Thomas of Aquinas' commentary of Aristotle Politics (1492) politia by res publica. ${ }^{194}$

The larger context in which this term was used merits a closer examination. James Hankins (2005) has discussed the changes the word respublica underwent during the $15^{\text {th }}$ cent. from the scholastic meaning to the sense it received during the later Renaissance. Starting with antiquity, he draws attention to the fact that in Aristotle politeia ( $\pi \mathrm{o} \lambda \iota \tau \varepsilon i \alpha)$ is used both in a generic meaning, including all forms of government, and a specific one, referring

191 Bruni ed. 1469 f. $122^{\mathrm{r}}$ (= III 13 1284a26), s. above n. 188. Tyrannicus is used by Cic. De Legibus I 15.42.

192 1285a17: "among some barbarians"; a30: "among the Greeks of old."

193 Constitutio became in English constitution, cf. Grimm, in Brunner et al. (eds.) 2004, p. 865 f. (in German Verfassung). Greek politeia as political order lost relevance when it assumed the designation for the institution of public order, the police, German Polizei, cf. F.-L. Knemeyer, art. "Polizei", in Brunner et al. (eds.) 2004, vol. 5, p. 875-897.

194 Mager in Brunner et al. (eds.) 2004, vol. 5, p. 566. cf. ibid. p. 567: "Die Belege für die seit Leonardo Brunis Übersetzung von Aristoteles' "Politik" gängig gewordene Verwendung von 'res publica' im Sinne von 'politia' sind seit dem 15. Jahrhundert Legion." 
to a form of government that is based on hoplites (or, one might add: a mixed constitution combining elements of democracy and oligarchy). In Latin, Hankins distinguishes as meanings of respublica "public affairs", "public good", "the state" or in a pregnant sense a "free state" as opposed to tyranny. He points out that in Cicero respublica carries moral connotations since under the government of a respublica the powerful should exercise restraint, place the common good over self-interest and share power instead of aspiring to unrestrained dominance. He states that the Greek word politeia by comparison "is much more value-neutral and analytical" and contrasts this with Latin respublica: "to call a state a respublica implies that it is a good form of government as opposed to a tyranny or a government in which private interests prevail over the common good" (p. 489 f.). In scholastic philosophy, respublica is never used to refer to non-monarchical regimes whereas in the second half of the $15^{\text {th }}$ century respublica was increasingly used to stand for 'non-monarchical regime'. ${ }^{195}$ Hankins does not assign a role to Bruni "in the appropriation of the word respublica by non-monarchical regimes" (p. 492) ${ }^{196}$ He dates the

195 Hankins 2005, p. 493. Among pre-humanistic writers there were (with a few exceptions) "no signs of the later disposition to use the term res publica to distinguish such elective forms of government from hereditary monarchies." One cannot find either Cicero's notion that such elective regimes were "the only forms of res publica truly worthy of the name," Q. Skinner, "The vocabulary of Renaissance Republicanism: A Cultural longue-durée?”, in: A. Brown (ed.), Language and images of Renaissance Italy, Oxford 1995 (87-110), 101. Cf. Mornhaupt, art. "Verfassung I", in Brunner et al. (eds.) 2004, vol. 6, p. 831-862.

196 Hankins 2005, bases his observations on Bruni's literary works and part of his correspondence. His statement: Bruni "prefers popularis status or popularis forma as the equivalent of politeia in the specific sense" (p. 492) is, however, not always correct for Bruni's translation of the Politics. In the taxonomy of constitutions in III $71279 \mathrm{a} 38 \mathrm{f}$. he trans-

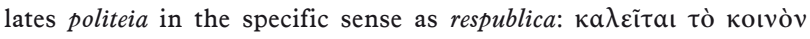

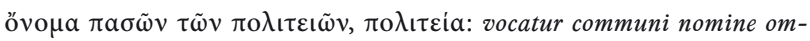
nium rerum publicarum, respublica (ed. Paris 1526 f. 43 ${ }^{\mathrm{V}}$ ), similarly his translation of IV $71293 \mathrm{a} 40$ ed. Paris $1526 \mathrm{f} .63^{\mathrm{v}}$. Popularis status is the term for democracy in III $71279 \mathrm{~b} 6$ where he translates the degeneration of politeiai in the specific sense into democracies by: ex republica autem in popularem statum, ed. Paris 1526 f. $43^{\mathrm{v}}$, s. above p. 39 n. 151. 
use of respublica in the generic meaning ${ }^{197}$ to the second half of the fifteenth century, when it began "to stand for 'non-monarchical regime'" (p. 493), but considers that it might go back to the beginning of the century as evidenced by Vergerio's treatise $D e$ Republica Veneta of 1400/03 (p. 494). Hankins suggests that this development could be due to the recovery of Tacitus for whom the respublica was a period characterized by freedom, an understanding of respublica Hankins finds in Bruni's periodization of Roman history (p. 493). With regard to Aristotle, Hankins argues that "the 'Aristotelian sense' of republic" continued to be used by monarchical writers, but was challenged by the 'Machiavellian sense', "for it was surely Machiavelli's authority that was responsible for the triumph of the new, Renaissance meaning of respublica as equivalent to 'non-monarchical regime'" (p. 498).

Hankins' concern is not ancient Greek political terminology but the question whether the republican ideals, the qualities of prudence, character, education, and civic values such as loyalty, love of the country, and devotion to the common good originate in Renaissance republics and were defined against the threat of tyrants in Italy, but later copied by monarchical regimes and nonrepublican ideology. Hankins dismisses this theory, which had been set forth by Hans Baron and others, by pointing out that monarchists like Vergerio espoused the same qualities. He argues that 'monarchical' or 'signorial' humanists shared the same values, however, they differed mainly in their understanding of freedom and equality (p. 504). Against this commonality, "the ideological use of respublica in the specific sense" (Hankins 2005, p. 498) is a new development, possibly influenced by a tradition going back to Cicero or Tacitus. Hankins speaks of a "relatively late emergence of the modern usages of the word respublica" (p. 500).

\footnotetext{
For the inconsistency in Bruni's usage s. N. Rubinstein, "Florentine Constitutionalism and Medici Ascendancy in the fifteenth century," in N. Rubinstein (ed.), Studies in Italian history in the Middle Ages and the Renaissance, Evanston 1968 (442-462), 447 n. 3.

197 It is, however, not "the best constitution for most cities" (Hankins 2005, p. 293). This constitution is discussed at Arist. Politics IV 11, but not called a politeia.
} 
It seems to me that the Greek tradition has been ignored here. While it is true that at Politics III 6-7 the two monarchical regimes, kingship and tyranny, are listed among the politeiai ( $\pi 0-$

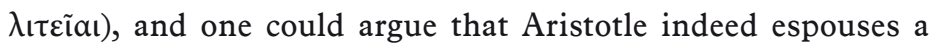
concept of regimes that is "much more value-neutral", and not "freighted with positive moral connotations" (Hankins 2005, p. 489) these chapters are by no means representative for Aristotle's constitutional theory; books IV-VI offer much more nuanced explanations. There Aristotle distinguishes or contrasts politeia on the one hand and monarchy, that is tyranny and/ or kingship, on the other, ${ }^{198}$ and he denies a radical, anarchic democracy the qualification to count as a politeia. ${ }^{199}$ According to Politics IV the best constitutions represent the middle from which there are deviation forms in two opposite directions: $:^{200}$ the regimes of the masses, on the one hand, and those of a few or one, on the other, are no longer politeiai when they are not governed by laws. ${ }^{201}$ Among the forms of rule, Aristotle distinguishes already in Politics $\mathrm{I}^{202}$ one that is exercised among

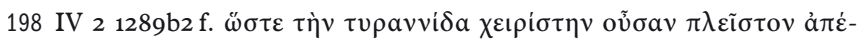
$\chi \varepsilon เ v \pi \mathrm{o} \lambda ı \varepsilon \varepsilon$ a, , similarly $81293 \mathrm{~b} 27 \mathrm{ff}$. For the distinction of politeiai

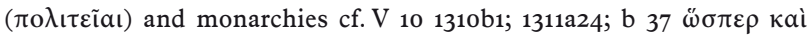

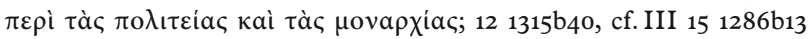
(cf. Schütrumpf, Aristoteles Politik 1991, vol. 2, p. 554 f., n. on 1286b12; p. 342 n. on II 101272 b2; p. 466 n. on III 7 1279a37. The title of Raffaele Lippo Brandolini's treatise De comparatione regni et reipublicae (cited by Hankins 2005, p. 497; written ca. 1490) could reflect Aristotelian terminology as introduced into Latin by Bruni's translation.

199 IV 4 1292a10-32; cf. VII 4 1326b3-7. For Cic. a corrupt state retains only the word res publica, but has lost it in truth, De Republica V $1.2 \mathrm{rem}$ publicam verbo retinemus, re ipsa vero iam pridem amisimus. Bruni did not know Cic.'s De Republica I-V, but he could be familiar with Aug. De civitate Dei II 21 where the result of the same conditions is described as non iam vitiosam, sicut pridie fuerat disputatum, sed, sicut ratio ex illis definitionibus conexa docuisset, omnino nullam esse rem publicam.

200 IV 3 1290a24-29.

201 For democracy see above p. 39 n. 151; p. 155 and 50 n. 196. A radical oligarchy that no longer follows laws is the equivalent of tyranny and is given the name dynasteia: IV $51292 b_{5}-10$.

202 I 121259 b1 ff. At Eudemian Ethics VII 10 1242b22-31 Aristotle distinguishes the rule among citizens (politike) from one that is exercised by a king. 
citizens fashion ( $\pi$ o $\lambda_{\iota} \tau \iota \kappa \tilde{\omega} \varsigma$, politikōs) from that of a king ( $\beta a \sigma l-$ $\lambda\left(\kappa \tilde{\omega} \varsigma\right.$, basilikōs). ${ }^{203}$

When Bruni in his letter to the Emperor Sigismund of December 1413 explained the political system of Florence, he absolves this task by outlining the complete system of six constitutions in a way which reminds of Aristotle Nicomachean Ethics VIII 12 (1160a31 ff.), and by placing Florence's political system into this framework, referring to its institutions, the character of its constitution as status popularis, the working of the government with term limits for some of its officials, the role of law and justice, the liberty and equality its citizens enjoyed ${ }^{204}$ he echoes fundamental concepts of Aristotle's Politics. After all, Aristotle

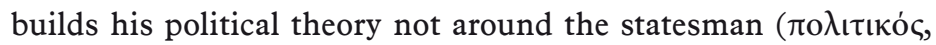
politikos) but the city and its 'parts', the citizens (III 1). ${ }^{205}$

The political rule is exercised over citizens who are free and equal $^{206}$ and who do no longer tolerate the rule of one man. The passage Politics III $15^{207}$ where Aristotle makes this point is translated by Bruni: non amplius toleraverunt regem, sed commune quiddam quaerentes, respublicas constituere ${ }^{208}$ As translator of Aristotle, Bruni is familiar with the contrast of monarch (rex) and respublica as forms of government that are opposed to one another not simply in terms of competing ideologies, but of the reaction of the people who are unwilling to put up with the rule of one man. It should be stressed here that the contrast of monarch (rex) and respublica, which is in Aristotle only implied is actually created in Bruni's translation because he added the object regem, king, to the verb 'tolerated' which in the Greek text is used without an object. Clearly he did justice to the sense of the Aristotelian passage

203 At Politics III $171287 \mathrm{~b} 38 \mathrm{f}$. Aristotle distinguishes a different form of 'right' ( $\delta$ íkatov) appropriate to kingship and one appropriate to a community governed by citizens, cf. above p. 45 n. 179.

204 The text in Baron ${ }^{2} 1968$, p. 181-184; on the authorship and date ibid. 173-181; Rubinstein (1987) 2004, p. 325.

205 S. Schütrumpf, Aristoteles Politik Buch I, vol. 1, 1991, p. 180-182.

206 Arist. Politics III $41277 \mathrm{~b} 7 \mathrm{f}$.

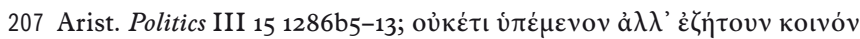

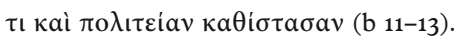

208 Ed. Paris 1526 f. $54^{\mathrm{r}}$. 
but brought in almost a rhetorical fashion to the foreground the contrast of rex and respublica as regimes that are incompatible with one another. In his translation the resistance of the subjects who will establish a politeia is not pointed against the political system or their own lack of political rights as the Greek could be understood but against the king. One might add that other Greek authors of the $4^{\text {th }}$ cent. BC used the same contrast of politeia and monarchy or tyranny. ${ }^{209}$

Therefore, the meaning of respublica that became prevalent at the end of the $15^{\text {th }}$ cent. could be considered good classical use and might well owe its existence to the classical Greek texts that were studied so intensively during that period. There is a further argument supporting this view, and that is the fact that, according to Hankins (2005, p. 494), the lexical opposite of respublica is not only tyrannia but "studium partis (factionalism)" as well. This contrast can be found in Plato's Laws VIII 832c, where the Greek philosopher denies that the regimes of democracy, oligar-

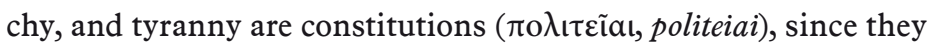
should be most fittingly be called 'states of factions' ( $\sigma \tau \alpha \sigma i \omega \tau \varepsilon \tilde{\alpha} \alpha$, stasiōteiai).

If it is correct that the political terminology used in the second half of the $15^{\text {th }}$ cent. follows, or is at least consistent with, that of Greek texts of the $4^{\text {th }}$ cent. BC, then one should not contrast, with Hankins (2005, p. 498), an "older understanding (which I would like to christen the 'Aristotelian sense' of republic)" with the "Machiavellian sense", that is "the new, Renaissance meaning of respublica as equivalent to "non-monarchical regime". On the

209 Isocrates or. 4.125: "in earlier times the Spartans used to remove tyrants and help the people, but now ... they fight against constitutional

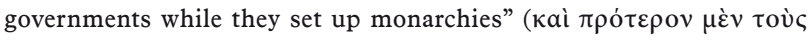

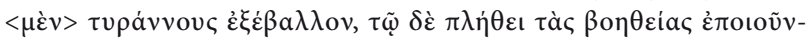

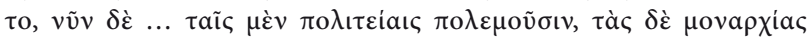
$\sigma v \gamma \kappa \alpha \theta \iota \tau \tau \tilde{a} \sigma \iota v)$; cf. ep.4.6; 6.11; Xenophon Hellenika VI 3.8: "you Spartans seem to enjoy tyrannical regimes more than constitutional

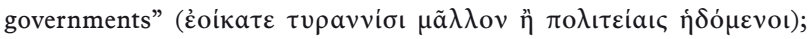
Demosthenes or. 1.5: "generally a tyrannical regime is in my opinion

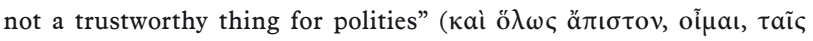

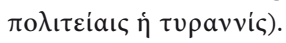


other hand, if the contrast of republics and monarchical regimes, including tyrannies, does reflect the distinction made by $4^{\text {th }}$ cent.

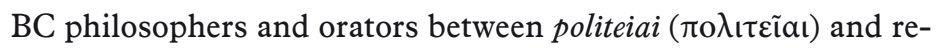
gimes like tyranny or radical democracies that do not deserve to

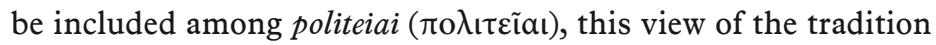
could support Hankin's argument that it did not need Renaissance republics in their fight for freedom to formulate these concepts. One finds this concept expressed in Bruni's translation of Politics IV 4, a section (1292a10-32) which argues that radical democracy is analogous to "tyranny among monarchies" and ends with the statement that cites with approval someone who declares such a democracy is not a politeia ( $\left.\pi 0 \lambda_{\imath} \tau \varepsilon i \alpha\right)$ : "rightly seem those to voice their blame who say that a government of this kind is democratic, but not a form of republic. For where laws cannot prevail there is no republic" (Merito igitur reprehendere videntur qui dicunt huiusmodi popularem esse potentiam, non autem reipublicae speciem. ubi enim leges dominari non praevalent non est respublica, ed. 1526 p. $61^{\mathrm{r}}$ ). Bruni's translation of Aristotle's Politics should be included among those texts that shaped the notion of respublica as a form of government that is opposed to monarchy. This is, however, only one side of the coin. Aristotle argues in Politics III 17 that under certain, rare conditions the absolute rule of one man would be the appropriate form of government and the only option is that all others obey such a man (1288a28 $\pi \varepsilon i \theta \varepsilon \sigma \theta a$ ।

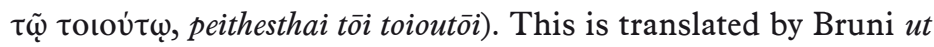
huic suadenti pareatur (ed. 1469 p. 126 $6^{\mathrm{v}}$ )-suadenti is Bruni's addition and makes the absolute rule of this one man look more benevolent. Instead of giving advice (suadere), he could give orders or take actions (of the kind Plato mentions in Politicus 293d).

In a review of the translation of Plato's Republic by K. Preisendanz (1909) ${ }^{210} \mathrm{O}$. Weinreich touched briefly on the beginnings of translations of Greek philosophical texts into Latin. He referred to the role Petrarch played in turning the philosophical interest

210 O. Weinreich, Ausgewählte Schriften I (1907-1921), ed. K. Wille, vol. 1, Amsterdam 1969, 12-15, review of K. Preisendanz, Platons Staat. Ins Deutsche übertragen, Jena 1909. 
away from Aristotle to Plato. Weinreich refers to the translations of Plato into Latin down to the masterwork by Ficino and argues that at that time the controversy over the rank of Plato or Aristotle respectively was settled: "Plato prevailed." 211 This reflects the outdated view according to which during the Middle Ages Aristotle was the dominant philosopher whereas in the Renaissance he was dethroned by Plato. James Hankins has countered that the Renaissance "might with perfect justice be styled ... an Age of Aristotle", and he singles out Bruni as "the first and in some ways the most characteristic member of this tradition of humanistic Aristotelianism." ${ }^{212}$

Petrarch's attack against Aristotle reached its climax in his De sui ipsius et multorum ignorantia ${ }^{213}$ of 1367 . This work contains not only a harsh criticism of Aristotle, but of the ignorant crowd that follows him blindly and rejects angrily any objection against him. Petrarch possesses the courage to undertake this criticism. In his critical comments on Aristotle's Nicomachean Ethics he concedes that Aristotle defined virtue with great acumen. After having learned this from him, he had now a better knowledge of virtue than previously, however, he did not change: "unchanged is the mind as it was, the desire is unchanged, unchanged am I" (idem est animus qui fuerat, voluntasque eadem, idem ego). ${ }^{214}$ To know is one thing, to desire is a different issue. For Petrarch, Aristotle succeeded in teaching what virtue is, however he failed to win over one's heart because Aristotle lacked the diction needed to

211 "Platon siegte", Weinreich (s. previous n.) p. 13, cf. Baron 1928, p. XXVI: "Siegeszug des Platonismus." However, the fact that Bruni's translations of Plato were replaced by those of Ficino does not affect the success of Bruni's translations of Aristotle, s. below p. 59; 64 .

212 In: Griffiths, Hankins, Thompson 1987, p. 259 f., cf. id. 2003, p. 186.

213 Ed. by E. Fenzi 1999.

214 Petrarch, De sui ipsius et multorum ignorantia p. 266 ed. Fenzi: idem est animus qui fuerat, voluntasque eadem, idem ego. Aliud est enim scire atque aliud amare, aliud intellegere atque aliud velle. Docet ille, non infitior, quid est virtus; at stimulos ac verborum faces, quibus ad amorem virtutis vitiique odium mens urgetur atque incenditur, lectio illa vel non habet, vel paucissimos habet. Quos qui querit, apud nostros, precipue Ciceronem atque Anneum inveniet ... 
instill desire for the good and resentment of what is bad. This, Petrarch continues, one finds in Cicero and Seneca. While in his ethical views Petrarch is to a certain degree influenced by Augustine, ${ }^{215}$ in his account of how one should win over a person he shows the influence of Cicero. According to the Brutus one of the three goals to be accomplished by rhetoric is that the listener be moved rather deeply, moveri vehementius, ${ }^{216}$ something Aristotle did not accomplish as Petrarch claims. Petrarch's criticism of Aristotle's ethical writings reminds us of Cicero's criticism of the Stoics when they write on the same subject: "What? Could a Stoic arouse enthusiasm? He will rather immediately drown any enthusiasm if he received someone full of zeal." ${ }^{17}$

Bruni did not share this negative judgment of Aristotle. In his work Vita Aristotelis of $1429^{218}$ he contrasts the views held by Plato and Aristotle respectively and voices his dismay over some of the regulations proposed by Plato in the Republic, such as the arrangement that women belong to all or that owning any possessions is prohibited, since all this is at odds with present custom. ${ }^{219}$ Apart from arguments on the content of the Republic, Bruni gives a thorough explanation of the high quality of the style, that is the rhetorical style, of the works of Aristotle. ${ }^{220} \mathrm{He}$ admits that certain learned men who do not know Greek would refuse to believe him. ${ }^{21}$ Those who know Aristotle only from his translations lack

215 Fenzi ibid. n. 452, p. 451-453.

216 Cic. Brutus 185: Tria sunt enim ... quae sint efficienda dicendo: ut doceatur is, apud quem dicetur, ut delectetur, ut moveatur vehementius; De optimo genere oratorum 1.3: Optimus est enim orator qui dicendo animos audientium et docet et delectat et permovet.

217 De Finibus IV 3.7: Quid? Ille incendat? Restinguet citius, si ardentem acceperit.

218 Partly reprinted in Baron 1928, p. 41-49. For the date s. ibid. p. 174.

219 ab hoc nostro usu consuetudineque vivendi plurimum abhorrent, p. 45 ed. Baron, translated by Griffiths, Hankins, Thompson 1987, VI:3, p. 289. The same argument is found in Bruni's letter, book 9.5(4) to Niccolò Ceva of 1441 (Luiso p. 150 f.). Bruni echoes Cic. De oratore I 52.224 .

220 Cf. Botley 2004, p. 42-62.

221 Bruni, Vita Aristotelis p. 46 ed. Baron: apud quosdam doctos viros, Graecarum tamen litterarum ignaros, fidem non fieri. Bruni had reason to insist 
what is needed in order to appreciate his style. If Aristotle were still alive, he would have denied that he wrote these works which circulated under his name. ${ }^{222} \mathrm{He}$ was the most polished author. If someone would not believe him, Bruni, he should believe Cicero. Differently than in the argument put forward by Petrarch, Cicero is no longer the author with perfect style-in contrast with Aristotle who, for Petrarch, is incapable of moving the reader-but Cicero is now the key witness for the rhetorical quality of the very same Aristotle.23

Nine years later Bruni completed his translation of the Politics. In one of the two preserved prefaces he states that the reason for this undertaking was the same as in the case of the earlier translation of the Nicomachean Ethics, that is the recognition that Greek works written in the most elegant style were reduced by the incompetence of a bad translator to ridiculous ineptitude. ${ }^{224}$ Bruni is now able to refer to the success of his translation of the Nicomachean Ethics. Its usefulness is proven by the fact that truly educated men embraced these books. The effect of his translation was that the understanding of these issues received the highest elucidation. ${ }^{225}$

on this issue at a different occasion, namely when Alfonso of Cartagena, who did not know Greek, attacked his translation of the Nicomachean Ethics, cf. Bruni's letter to F. Picolpassi of 1438, book 8.2 (p. 137 f. Luiso), no 5, p. 194 Birkenmajer, cf. p. 201, cf. 202: Quaero num Graece sciat? "non scio, inquit ...” and: qui Graecarum litterarum penitus est ignarus, itaque neque vim verbi neque testimonium scriptorum in ea lingua capere potest.

222 He repeats this idea in De Interpretatione [45] p. 122, cf. Dialogus p. 58 ed. Garin: Aristotle would not recognize from the translation that these were his works.

223 Vita Aristotelis p. 46 ed. Baron Ille (i.e. Aristoteles) enim politissimus scriptor esse voluit et, quod voluit, curavit et, quod curavit, assecutus est. Verum, quia verba fidem non faciunt mea, Marci Tullii accedat auctoritas. Cui enim hi de eloquentia iudicanti credent, si Marci Tullii iudicio non credent? Cf. Dialogus p. 58 ed. Garin; Praemissio Ethicorum p. 77 ed. Baron.

224 Bruni, Praemissio Politicorum p. 73 f. ed. Baron: Nam cum viderem hos Aristotelis libros, qui apud Graecos elegantissimo stilo perscripti sunt, vitio mali interpretis ad ridiculam quamdam ineptitudinem esse redactos ..., translated in: Griffiths, Hankins, Thompson 1987, II 7:VI, p. 163.

225 Ibid. p. 74: ita postmodum eos libros complexi sunt, ut in maximam lucem illarum rerum cognitio sit perducta. 
Bruni claims that he advanced the understanding (cognitio) of the matters discussed in the Nicomachean Ethics-this is a much more modest claim than the objective pursued by Petrarch, namely that an ethical treatise of a philosopher change the life of his reader. Bruni is satisfied with having clarified the argument and having furthered the understanding (cognitio) of this Aristotelian work. ${ }^{226}$ Bruni might here echo Cicero, who viewed a translation based on its impact on the knowledge (cognitio) of the citizens-Cicero was talking of a translation of Plato and Aristotle, ${ }^{227}$ the very issue Bruni dealt with in his reply to Petrarch.

Bruni referred to the success of his translation of the Nicomachean Ethics. ${ }^{28}$ The number of manuscript copies and early printed editions of Bruni's translation of this work, of the Oeconomica, and the Politics ${ }^{229}$ proves its popularity. In the late $15^{\text {th }}$ cent. Bruni's translation of the Politics replaced that of William

226 Hankins 2006b, p. 136.

227 De Finibus I 3.7, cited above p. 31 n. 113. For removing obscurity s. above p. 29 n. 99 and 100.

228 Letter to F. Picolpassi of Oct. 15 1435, book 7.4 (p. 127 f. Luiso), no 3, p. 187 ed. Birkenmajer, about his translation of the Nicomachean Ethics: quam, simul atque edita est, sic arripuerunt homines, ut momento paene temporis non solum Italia voluminibus eius repleta sit, verum etiam ad extremas terrarum oras convolarit, ut publica iam lectione studiorum celebretur. Battista de' Giudici confirms this when he explains how difficult it would be to criticize Bruni because of the great number of people who follow his authority on account of the rhetoric found in his translation, cited in Grabmann 1926, p. 444 n. 11.

229 Bruni's translation of the Nicomachean Ethics survives in 285 manuscripts and 31 editions, of the Oeconomica in 260 manuscripts and 55 editions, and of the Politics in 206 manuscripts and 51 editions, Hankins 2003, p. 191.-Bruni's translation of the Politics received distinguished place in the history of scholarship. The edition Ethica, Politica, Oeconomica, Leonardo Aretino interprete, Strasbourg (Johann Metelin) before 10.4. 1469, is according to L.W. Riley, Aristotle. Texts and commentaries to 1700 in the University of Pennsylvania Library, Philadelphia 1961, p. 33, the "first printed edition of Aristotle." I inspected copies at the Staatsbibliothek Berlin and the Beineke library at Yale University, New Haven. It has been digitalized by the Münchener DigitalisierungsZentrum, call number BSB-Ink A-685 GW 2367. 


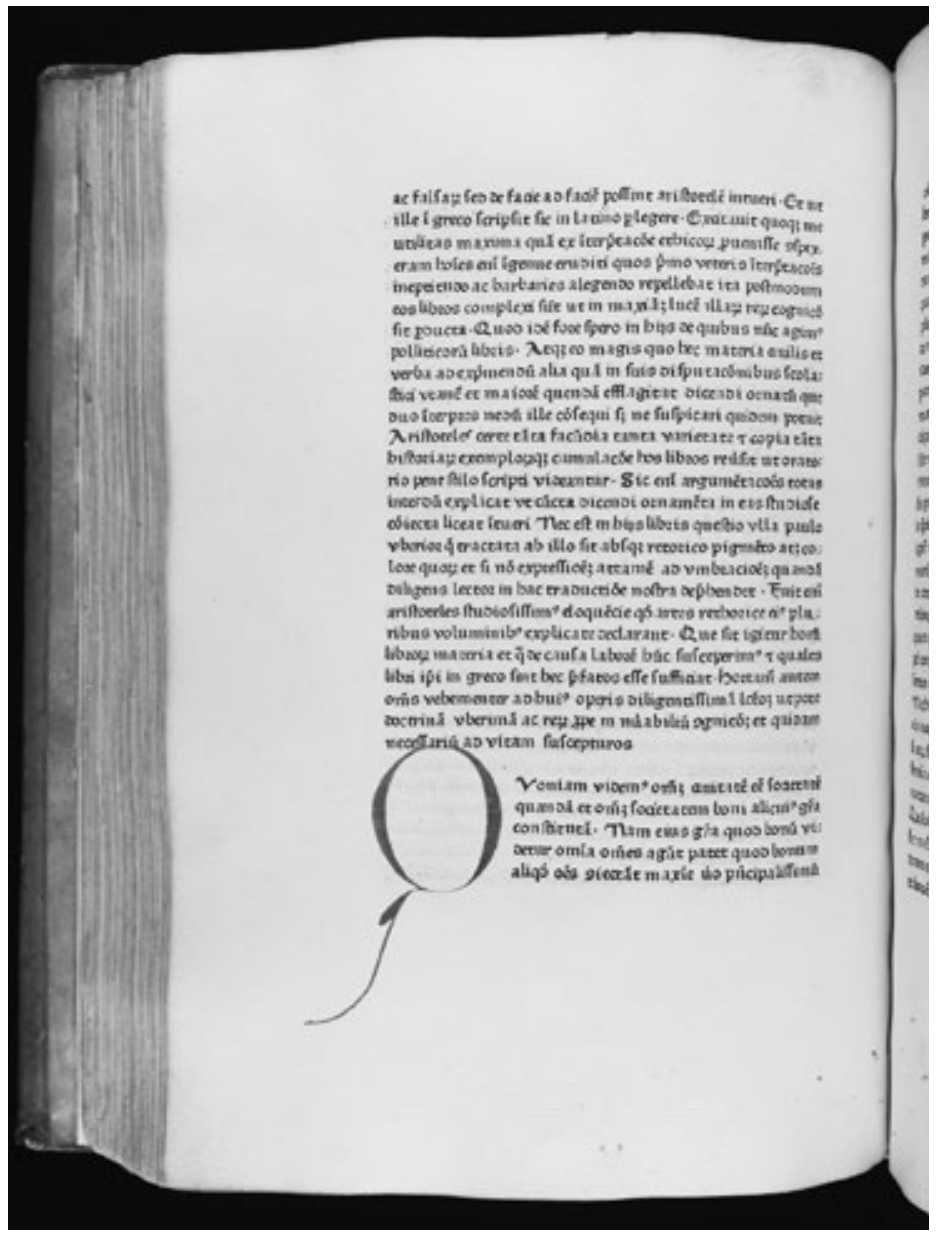

1 Aristotelis Ethica ad Nicomachum; Politica et Oeconomica Leonardo Aretino interprete, Strasbourg ap. Johann Mentelin (before April 10) 1469, f. 89 v, translation of Pol. 1.1 1252a1-a5 


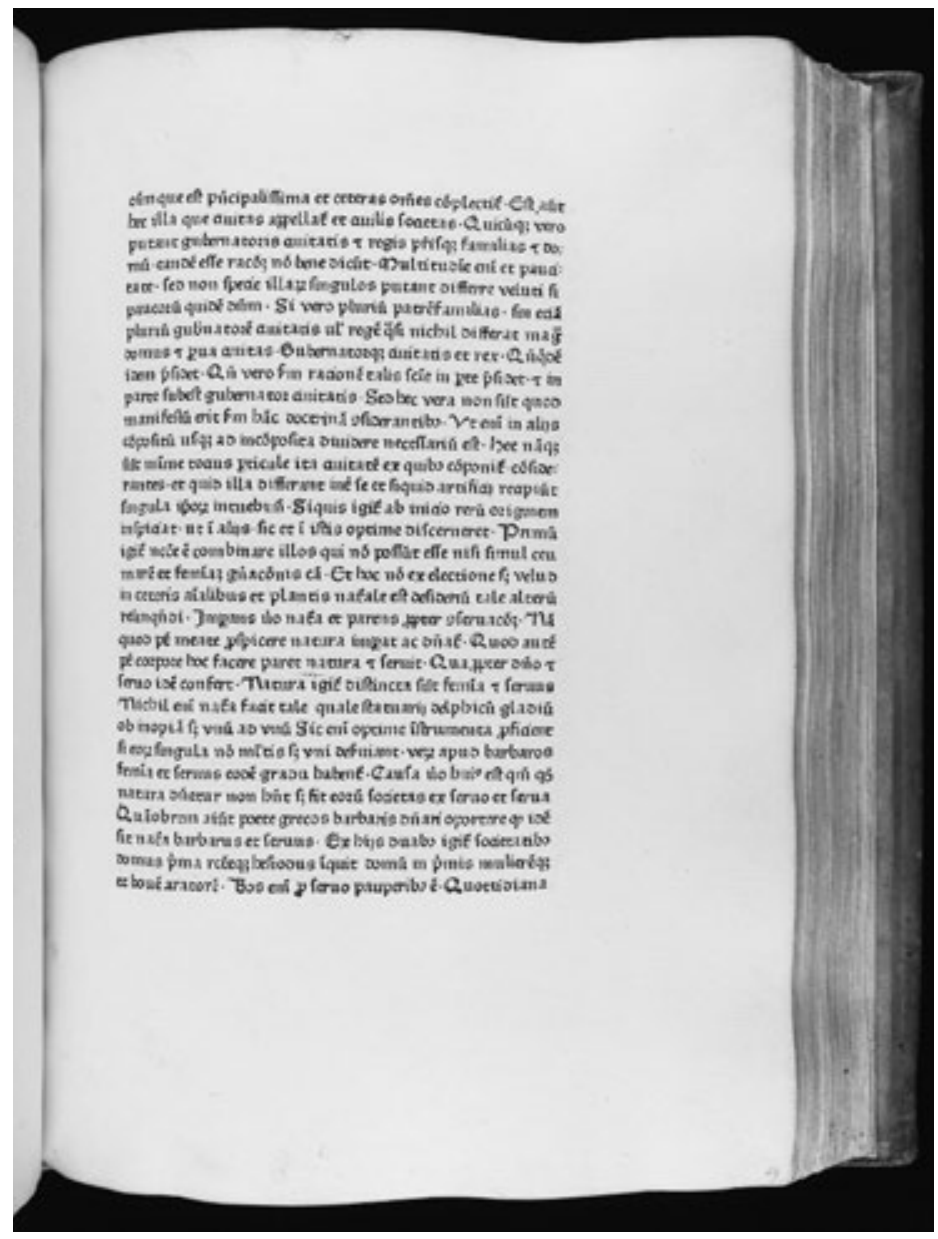

2 Aristotelis Ethica ..., f. 90 r, translation of Pol. 1.1 1252a5-b14 


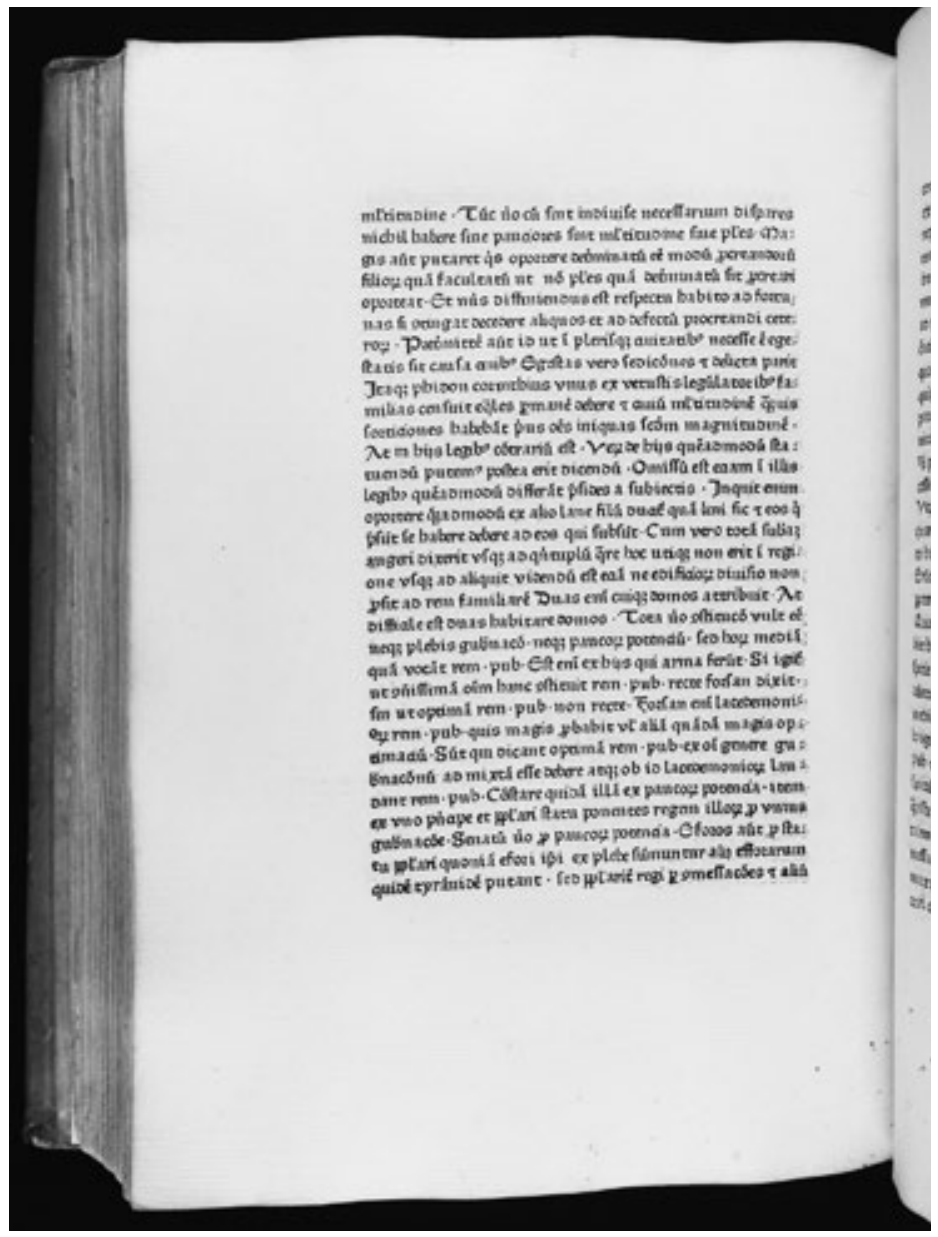

3 Aristotelis Ethica ...f. 103 v, translation of Pol. 2.6 1265b4-b41 


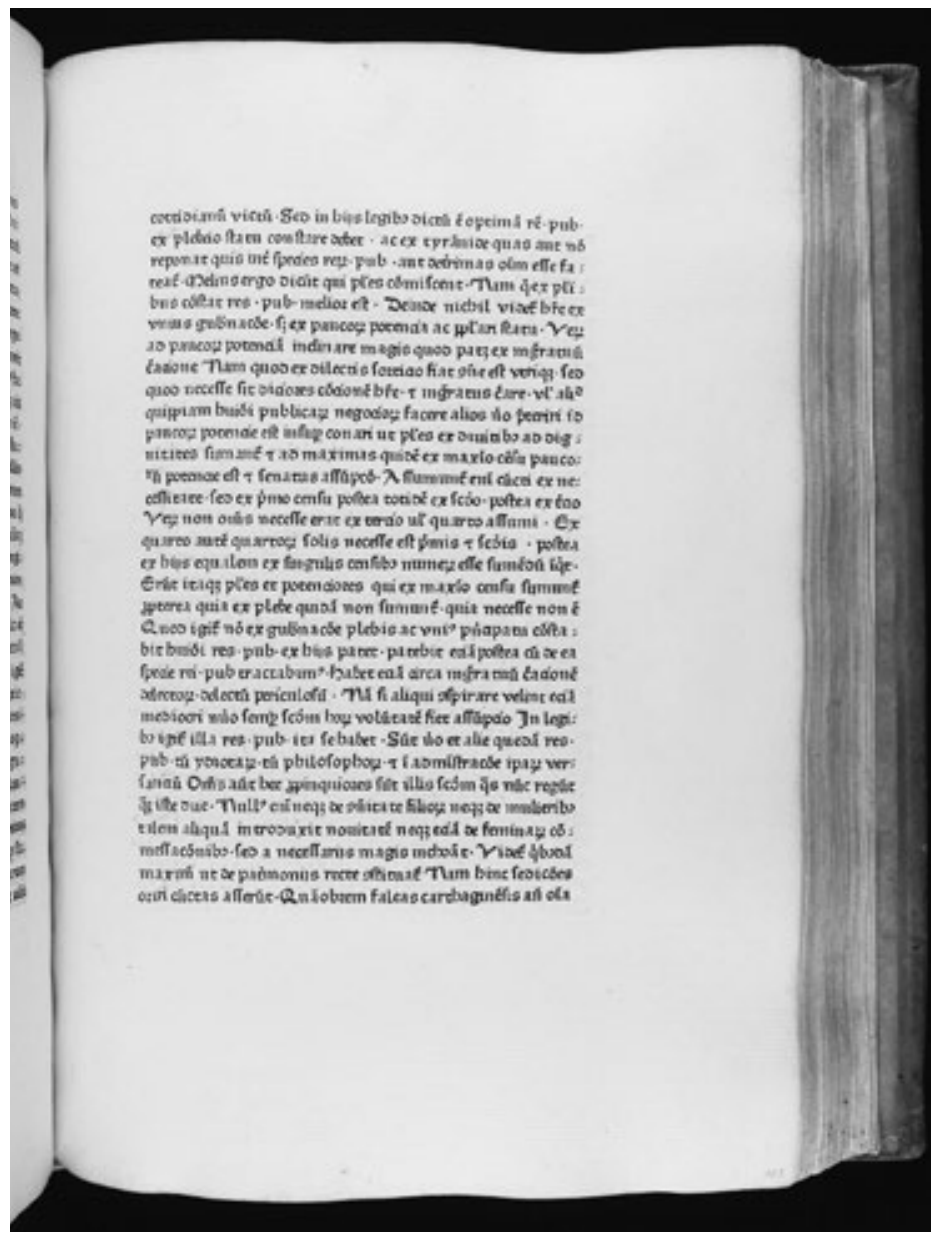

4 Aristotelis Ethica ...f. 104 r, translation of Pol. 2.6 1265b41-7 1266a38 
of Moerbeke in the commentary to the Politics by Thomas of Aquinas. ${ }^{230} \mathrm{His}$ commentary continued to draw the attention of theologians and philosophers, but the Latin translation of Aristotle's Politics on which it was based and to which Thomas of Aquinas owed his knowledge of this Aristotelian text was substituted at the end of the fifteenth century by the translation of Bruni. The same happened with the Latin translation of the Nicomachean Ethics. ${ }^{231}$ Bruni's translation of Aristotle's Politics "was the most popular translation of that text until well into the sixteenth century, and was used as a basis of commentaries by Donato Acciaiuoli, Lefèvre d'Étaples, Octavianus Ferrarius, Melanchthon and probably others." ${ }^{232}$ In the Iuntina edition of Thomas of Aquinas' commentary of Aristotle's Politics (Venice 1568), in which the translation of Wilhelm of Moerbeke had been replaced by that of L. Bruni, the editor Iulius Martianus Rota adds separately "the old translation of the Politics (antiquam Politicorum interpretationem), without giving the name of the translator, justifying this enterprise "in order to protect this book, whatever its quality might be, against destruction" (quo liber iste qualiscumque, ab interitu vindicaretur, p. 133 ${ }^{\mathrm{v}}$ ). By then the survival of William's translation must have been in jeopardy. Rota explains that he provided the opportunity to read this translation for "whoever is an enthusiast of antiquity" (quisquis antiquitatis amator extiterit). Rota forestalls criticism that a reader could be offended by William's translation (nec si quid offendet, quod se remoretur, nos culpet). Now his translation was of interest only to lovers of ancient things and textual critics (s. above p. $16 \mathrm{n}$. 37).

230 Schmitt 1983, p. 20 . There were "at least five" printed editions of St. Thomas' commentary of the Politics together with Bruni's translation: Hankins in: Griffiths, Hankins, Thompson 1987, 355 n. 167.

231 S. Hankins 2003, p. 182 f. with n.14.

232 Hankins 2003, p. 182 f. Acciaiuoli 1429-1478; Lefèvre d'Étaples ca. 14551536; Octavianus Ferrarius ca. 1465-1517; Melanchthon 1497-1560. Bruni's translation in turn was replaced by those of Pier Vettori (14991585) and Denys Lambin (1520-1572): Hankins in Griffiths, Hankins, Thompson 1987, p. 355 n. 170. For the Latin translations of Aristotle s. Keßler 1995, p. X-XXV. 


\section{THE CONTROVERSY OVER BRUNI'S TRANSLATION- CONTEMPORARY AND MODERN}

Bruni's translation uses the classical Latin vocabulary and follows the order and structure of classical Latin according to the model of Cicero that was shared by other translators of the $16^{\text {th }}$ cent. Some went further than Bruni had done. Joachim Périon (1499-1559), for instance, produced translations ${ }^{233}$ that aspired to elegance, but lacked precision to such a degree that at times they bordered on paraphrases. Already in the $16^{\text {th }}$ cent. a reaction against this tendency set in. And today Périon is criticized for this approach. Charles Schmitt argued that Périon, misled by Cicero's characterization of Aristotle's style as flumen orationis aureum, "a golden stream of speech," put the poorly written Greek of Aristotle's text "into refined Ciceronian Latin", not seeing the difference between a philosophical text that aims at truth and a rhetorical style. ${ }^{234}$ This seems a new version of the controversy over the merit of Bruni's translation in comparison with that of William of Moerbeke which took place already during Bruni's lifetime.

Battista de' Giudici ( $†$ 1484) acknowledged the eloquence of Bruni's translation of the Nicomachean Ethics, but claimed that Bruni lacked the training needed to translate a philosophical text, proven by the fact that he was ignorant of the distinction between

233 Joachimus Perion, Aristotelis ad Nicomachum filium de moribus, quae Ethica nominantur, libri 10, per Nicolaum Grouchium [de Grouchy] corr. \& em., Paris 1555. S. Keßler 1995, p. XIII f.

234 Schmitt 1983, p. 73: "perhaps bewitched, as had been Bruni and others before him, by Cicero's description of Aristotle as flumen orationis aureum and by Quintilian's eloquendi suavitas, Périon took it upon himself to render these characterizations true by putting the crabbed and often corrupt Greek of the existing corpus Aristotelicum into refined Ciceronian Latin. In doing so not only did he fail to realize that philosophical and scientific writings, aiming as they do at truth, have more at stake than the polished verbiage of the rhetor ...” 
contrarius and contradictorius, and fell short of philosophical truth. For that reason he was inferior to the older translator who "more zealous for philosophical truth did not wish to speak so ornately, lest he fall into the errors in which that one (Bruni) lapsed." ${ }^{235}$ This remark is in line with with Boethius' principle that works in which understanding of things is sought, the uncorrupted truth and not the charm of a lucid style must be expressed. ${ }^{236}$

Alfonso of Cartagena (1384-1456), later bishop of Burgos (Castille), advanced similar arguments. ${ }^{27} \mathrm{He}$ associated philosophical knowledge (scientia) with a Latin language that is precise, used in its most correct sense, and fitting the simplicity of the issues discussed. ${ }^{238}$ Helene Harth ${ }^{239}$ has shown how Alfonso's views on translation were founded on the scholastic concept of a universal grammar, whose rational structure is determined by modi significandi, modes of meaning, that are based on modi essendi, modes of being, which are perceived by modi intellegendi, modes of understanding. With this approach, the goal is to express in translation the truth of the argument without caring about the semantic and stylistic specifics of the source. The truth that is found in Aristotle can be judged without knowledge of the language the author wrote in. For Bruni, on the other hand, there existed no absolute truth of reason, but ideas of a specific author who wrote in a specific historical and cultural context in a language that is shaped by the literary tradition and conventions of the people to whom the philosopher belonged. ${ }^{240}$ Alfonso's views on translation follow the tradition of the notion of the fidus

235 Antiquus interpres magis studens philosophice veritati non ideo ornate dicere voluit, ne in errores in quos iste lapsus est incideret, cited by Grabmann 1926, p. 444 n. 12, translation after Seigel 1968, p. 122 f.

236 In Isagogen Porphyrii commenta, CSEL vol. 48, 1906, p. 135 in his scriptis in quibus rerum cognitio queritur, non luculentae orationis lepos, sed incorrupta veritas exprimenda est.

237 In Liber Alphonsi episcopi Burgensis, no. 2, p. 162-186 ed. Birkenmajer. Cf. Hankins 2003, p. 200-211; Botley 2004, p. 53-58.

238 The translation has to be examined an simplicitatem rerum et restrictam proprietatem verborum observet, ibid. p. 175 ed. Birkenmajer.

239 Harth 1968, in particular p. 42-52.

240 Harth 1968, p. 48. 
interpres as it was first developed for the translation of the Holy Scripture which demanded that the translator refrains from allowing his understanding of the text to distort the truth of the work to be translated. ${ }^{241}$ In this tradition translation was strictly separated from expositio, ${ }^{242}$ which was a scholarly effort in its own right, pursued in commentaries.

Bruni's theory of translation and his translations make this separation of translation and explanation obsolete. For him a translation is no longer the attempt of reproducing faithfully, or slavishly, the Greek original in a different language with the result that the reader who tries to make sense of it to is often at a complete loss. ${ }^{243}$ Instead, translation is the self-confident act of an individual who undertakes the task of making the sense of the text comprehensible, without the enigmata of the old translation, ${ }^{244}$ at times by small additions (s. above p. 53; 55), however, eliminating the need of additional glosses or a commentary.

The second aspect addressed by Alfonso concerned rhetoric. Infusing rhetoric that aspires to charme of persuasion opens the possibility for errors and creates confusion. ${ }^{245}$ This applies

241 Harth 1968, p. 51 f.; see above p. 24.

242 Cf. Cincius Romanus in his report of Chrysoloras' position, cited by Keßler 1995, p. XI n. 16; see above p. 19.

243 J. Dunbabin, "The Reception and Interpretation of Aristotle's Politics", in CHLMPh (p. 723-737) p. 723 f. argues that William's translation is "in general, ... a very accurate rendering. Unfortunately accuracy is more than counterbalanced by unintelligibility." Therefore, the earliest Latin commentators had "to engage in the task which Moerbeke had declined, to explain what Aristotle was saying, using the methods of exposition."

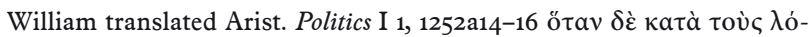

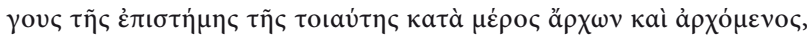

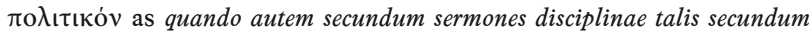
partem principans et subiectus, politicum (p. 2.6-8 ed.Susemihl). Here Rubinstein ([1987] 2004), p. 320 n. 20 comments: "This is a good example of the difficulties Moerbeke's translation was liable to present to commentators of the Politics." See above p. 15 with notes 34-36.

244 Praemissio Politicorum p. 74 ed. Baron, translated by Griffiths, Hankins, Thompson 1987, II 7:VI, p. 163. Cf. Hankins 2003, p. 199; 203.

245 Saepe enim elegantia sermonum, si non stricto iudicio dirigitur, simplicitatem rerum confundit, quod maxime rectum scientiae intellectum perturbat, Liber Alphonsi episcopi Burgensis, no 2, p. 175 ed. Birkenmajer. 
to Bruni's translations who, as Alfonso claimed, went so far as to subordinate philosophy to rhetoric. For Alfonso, the rhetorical style adopted by Bruni creates confusion whereas Bruni had maintained the opposite, namely that the earlier medieval translation were obscure, abstract and lacked the clarity of expression in an established language (s. above p. $29 \mathrm{f}$.). Bruni in his concept of translating does not only aim at reproducing the sense of the source in a clear way but at reproducing its literary qualities too. When Jerome claimed that he did not compromise with regard to sense, even if something with regard to words might be missing ${ }^{246}$ Bruni might disagree with this principle slightly insofar as he would not allow that either the sense or the high stylistic quality be sacrificed. ${ }^{247}$

Regarding Alfonso's reference to rhetoric, we will soon turn to the question whether Bruni added stylistic elements of rhetoric to a text which lacked them. In De Interpretatione Bruni compares the text he translates with a work of art, ${ }^{248}$ which turns the translator into an artist. ${ }^{249}$ As such he induces the reader to appreciate the artistic qualities of the original. Bruni had argued, and documented on the basis of Aristotelian passages, that Aristotle's style, like that of Plato, possessed remarkable literary qualities which have to be expressed by the translator. At least according to De Interpreratione ${ }^{250}$ there is no longer the contrast found in

246 Ep. 57.6.2, cited above p. 30 n. 103.

247 De Interpretatione [14] p. 86: Hec est enim optima interpretandi ratio ... ut neque sensibus verba neque verbis ipsis nitor ornatusque deficiat, preceded by nec aliter servare sensum commode poterit nisi sese insinuet ac inflectat per illius comprehensiones at ambitus cum verborum proprietate orationisque effigie, i.e. the preservation of the sense includes not only proper rendering of words but conveying an 'image of the speech.'

248 [2] p. 74, cf. [13] p. 84, cf. Botley 2004, p. 53 f.

249 De Interpretatione [5] p. 76-78.

250 Hankins 2003, p. 184 f. argues that for Bruni the character of translating, that is the degree of precision, varies according to the genre of the work being translated. This might well be the practice he followed, but it is not suggested as an option in De Interpretatione. The notion developed by Decembrio, Filelfo and George of Trebizond that different techniques of translation should be applied according to the variety of subject matters (Hankins ibid.) adopts Jerome's principles, s. above p. $23 \mathrm{f}$. 
Cicero De optimo genere oratorum 5.14 of translating like either an interpres or an orator. For Bruni, the translator is interpres and expresses all the rhetorical qualities of the source.

Two questions arise here: Did Bruni "mistakenly" (s. below p. $71 \mathrm{f}$. with n. 257) under Cicero's influence see in Aristotle rhetorical qualities which the works he translated did not have? And: did Bruni produce a translation which improperly displayed a rhetorical style to the degree that it distracted from the "simplicity of matters" as Alfonso had assumed?

Jerrold E. Seigel has argued that Bruni's approach to translation was influenced to some degree by that of Coluccio Salutati (1331-1406) who, although not knowing Greek, expressed to Antonio Loschi (1368-1441) dissatisfaction with an older translation of the Iliad and suggested improving on its literary qualities by adding decorations and splendor of language, in particular "conjunctions, exclamations, and interrogations." ${ }^{251}$ Salutati revised a Latin translation of Plutarch's De ira by Simon Attumano by inserting into the plain text exclamations and questions. ${ }^{252}$

While Bruni would agree with Salutati's criticism of the older translation he did not follow the sort of improvement Salutati had in mind ${ }^{253}$ I could not find in Bruni's translation of Aristotle's Politics passages which show rhetorical features like exclamations or interrogations where the Greek text did not have them. In fact, Politics III chapter 10 is written in a very rhetorical style with exclamations and interrogations but Bruni did not add to these features but remained almost disappointingly restrained. As far as I could observe, he was not guilty of either wrongdoing Alfonso associated with rhetoric, ${ }^{254}$ nor did he contract in

251 Seigel 1968, p. 117. Salutati's letter: Epistolario, book VII, no. 23, vol. II, p. 354-358 ed. Novati.

252 "For the sake of splendor or embellishment (ornatus) it is legitimate, as long as the sense is not altered, to add heat to the lukewarm quality of plain prose and to arouse through exclamations or the stimuli of questions," ornatus enim gratia, manente sententia, licitum est continue narrationis quendam teporem accendere et per exclamationes aut interrogationum stimulos excitare, Epistolario, book VIII, no. 23, vol. II, p. 483 ed. Novati.

253 Seigel 1968, p. 116-119.

254 S. above p. 46 n. 181. 
his translation in order to make a poignant and incisive remark, nor did he expand on the original for rhetorical reasons, ${ }^{255}$ he is definitely not more verbose. Already Baron observed that Bruni adhered to a style "that was closer to the precision and factual accuracy of the unrefined volgare than to all artificial sentence structures of Ciceronian eloquence. ${ }^{256}$

I have not seen evidence that would show that Bruni sacrificed precision for the sake of elegance. However, is elegance in a translation of Aristotle's treatises really incongruous with his style? Cicero's and Quintilian's characterizations of Aristotle's writings are commonly referred to the so-called Hellenistic Aristotle, that is his exoteric writings, mostly his dialogues which were known to Cicero, but are lost now, whereas the existing Corpus Aristotelicum does not enjoy a high reputation for its stylistic refinement. Seigel argued that Cicero's judgment which referred to Aristotle's now lost works was "mistakenly" applied by Bruni to the treatises of the surviving Aristotelian Corpus

$255 \mathrm{He}$ did occasionally expand in order to explain a term: at III 14 $1285 \mathrm{a} 28 \mathrm{f}$. where he contrasts the protection a king receives from his citizens with that of a tyrant provided by foreigners. Instead of translating 'foreigners' ( $\xi \varepsilon v \iota \kappa o ́ v)$ by a single word as William had done (extranei, p. 215.10 ed. Susemihl) Bruni chose ab extraneis mercede conductis (f. $51^{\mathrm{r}}$ ed. Paris 1526 ), clarifying that they were mercenaries. The

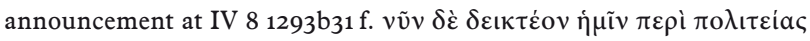
is rendered: Nunc autem es a nobis de illa quae communi nomine appellatur respublica ostendendum, ed. Paris $1526 \mathrm{f}$. $64^{\mathrm{r}}$-quae communi nomine appellatur is Bruni's addition which clarifies the ambiguous term; it is missing in William p. 407.3 f. ed. Susemihl. Another addition, that of regem, is discussed above p. 53; for suadenti cf. p. 55. Exaggerated is the judgment of Susemihl 1872, p. XXX: "Tantum enim abest (scil. a lectione codicum) ... Aretinum 'verbum pro verbo reddere solere', ut iuste saepius sensum multo magis quam litteram respexerit ... nec sit ab omni vitiosae negligentiae crimine liberandus. Saepius utitur tanta circuitione et circumscriptione, ut genuinorum scriptoris verborum vix vestigia recognoscas." Bruni stood in the tradition that privileged faithfulness to sense over that to words.

256 Baron 1928, p. XXIV f.: Bruni blieb "einer Schreibweise treu, die der Prägnanz und sachlichen Treffsicherheit des prunklosen Volgare näher stand als allen kunstvollen Satzbildungen ciceronianisch-literarischer Eloquenz." 
with the result that this caused him to "distort some features" of the Aristotelian writings he was dealing with. ${ }^{257}$ According to this view the stylistic qualities Bruni praised in Aristotle's work ${ }^{258}$ are not present in the works he translated. The influential Aristotelian scholar Werner Jaeger denied that the philosophical treatises are works of literature. ${ }^{259}$ Similarly Ingemar Düring characterized Aristotle's philosophical treatises: "unliterarische Prosa", ${ }^{260}$ prose without literary aspirations, and this is generally the judgment on Aristotle's style. If this judgment were correct, then the character of Bruni's and even more of Perion's translations would fail to understand and reproduce the genre of philosophical writings by dressing them up in a rhetorical manner.

At the end of the $19^{\text {th }}$ cent. Friedrich Blass discovered that Aristotle in the last two books of the Politics avoided hiatus, a stylistic practice which Plato began to adopt in his later dialogues. ${ }^{261}$ Clearly, Aristotle provided stylistic refinement here. In my opinion Aristotle, the author of the treatises of the Corpus, has been underrated as a writer who was aware of style, he has been underrated as a writer of literature. His awareness of stylistic features is documented in Poetics ch. 22 and Rhetoric III. I will argue that an analysis of the style of the Politics shows that he consciously employed rhetorical devices ${ }^{262}$ and that the ideals of

257 Seigel 1968, 110. Seigel's "mistakenly" is echoed by Keßler 1995, p. X n. 12 "sachlich falsch". Botley 2004, p. 43-45 argues that Bruni became over time increasingly certain of the rhetorical qualities of Aristotle's work, including his Physics and Metaphysics. Botley p. 49 shows that the rhetorical quality of Aristotelian works, here the Posterior Analytics, had already been maintained by Roberto Rossi in 1406, cf. ibid. p. 59 f. for Melanchthon and F. Burchard.

258 Cf. Botley 2004, p. 42-62.

259 W. Jaeger, Studien zur Entstehungsgeschichte der Metaphysik des Aristoteles, Berlin 1912, 133: "Die Lehrschriften sind überhaupt nicht Literatur." cf. G.E.R Lloyd, Aristotelian Explorations, Cambridge 1996, 2: "these are not works prepared for publication as literature;" similarly Hankins 2003, p. 198.

260 Aristoteles. Darstellung und Interpretation seines Denkens, Heidelberg 1966, p. 555 .

261 F. Blass, Die Attische Beredsamkeit, Leipzig II 1, ${ }^{2} 1892,140$.

262 I have discussed Aristotle's style in: "Form und Stil aristotelischer 
translation as employed by Bruni are not deplorable aberrations. I can here only refer to selected examples from Aristotle's Politics and Bruni's translation since a comprehensive comparison of Aristotle's Politics with Bruni's translation has not been done and would go beyond the scope of this essay. ${ }^{263}$

At Politics III 161287 a 23-25 Aristotle writes:

"issues which, as it seems, a law cannot determine a human

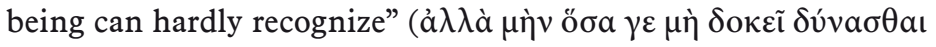

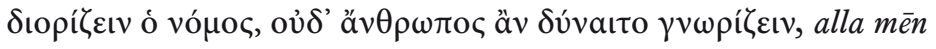
hosa ge mè dokei dynasthai diorizein ho nomos, oud' anthrōpos an

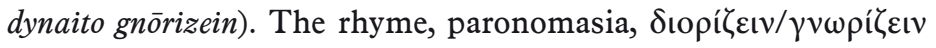
(diorizein/gnörizein), intensified by the repetition of two differ-

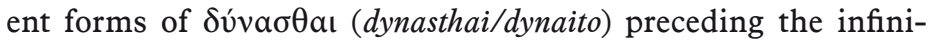
tives diorizein/gnōrizein, reminds of the style of Gorgias, but it is less obtrusive because of the chiastic position of the infinitives

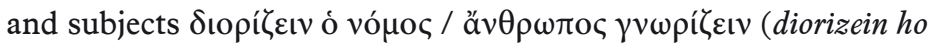
nomos / anthrōpos gnōrizein). At the same time, the two main verbs,

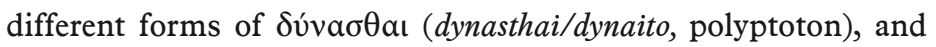
the dependent infinitives are arranged in parallel order so that chiasmus and parallelism are combined. The 15 words are chosen and arranged in a remarkably skillful way, employing traditional rhetorical devices in a less impertinent and much more tasteful way than we find it in Gorgias or Isocrates. William's translation at vero quecumque non videtur posse determinare lex, neque homo utique poterit nota facere (p. 228.8 ed. Susemihl) does not reproduce any of the stylistic features, and nota facere is mistaken, ${ }^{264}$ a verb like cognoscere was needed. Bruni translates:

Pragmatien" (1989), now in Schütrumpf, E., 2009, 146-159, and in Aristoteles Politik Buch I, 1991, vol.1, p. 65 with n. 2; Buch VII-VIII, 2005, vol. IV, p. $86 \mathrm{f}$.

263 The situation has not changed since Seigel's remark about the Nicomachean Ethics: "no modern scholar has undertaken this task (of collating the medieval version and that of Bruni with the Greek text) in full; it is to be hoped that someone will," p. 131. He adds that the few partial attempts "have not yielded results favorable to Bruni."

264 William was misled by the usual meaning of verbs with the ending

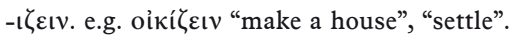


quecumque vero videntur per legem quidem determinari non posse, neque per hominem agnosci potuisse (ed. Paris 1526 p. $55^{\mathrm{v}}$ ).

He employs only parallelism, and since he could not imi-

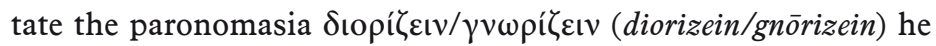
chose that of posse/potuisse and saves somehow Aristotle's stylistic intentions.

At VII 12, 1331 b 19-22, at a juncture where Aristotle ends his discussion of the desirable conditions of the best state in order to move on to the treatment of the constitution itself he remarks:

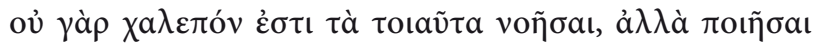
$\mu \tilde{\alpha} \lambda \lambda \mathrm{ov}$.

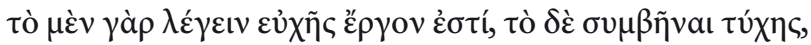
that is:

"for it is not difficult to think up such things, but rather to do them.

Since in order to express them one needs only wish, but (for them) to happen (one needs) fortune."

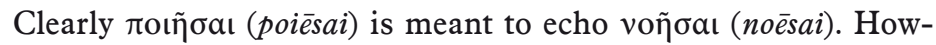
ever, Aristotle is not satisfied with employing this device (paro-

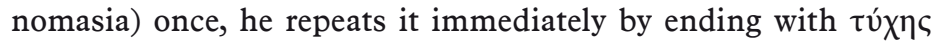

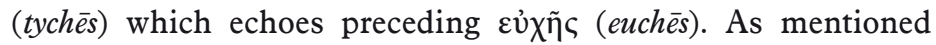
before, this statement is found at the end of a section. If one considers this passage remarkable one can find support for this view in Aristotle himself: at Rhetoric III 7 he deals with stylistic features which one can condone in an orator who speaks emo-

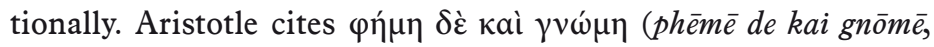
$1408 \mathrm{~b} 11 \mathrm{ff}$.) which Isocrates is supposed to have used at the end of the Panegyricus-according to our manuscripts Isocrates

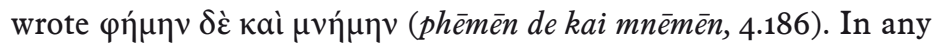
case Aristotle uses himself a rhetorical device which he says can be tolerated under certain circumstances, that is at the end of a speech, and he uses it in Politics VII 12 in the same situation, but goes even beyond Isocrates by using it twice. Let us turn to the Latin translations: William of Moerbeke translated: 
non enim difficile est talia intellegere, sed facere magis:

dicere quidem enim voti opus est, evenire autem fortunae, ${ }^{265}$ and Leonardo Bruni:

cum sint illa difficilia cognitu, sunt magis factu.

Dicere enim voti est, evenire autem fortunae.

William's version is clearly verbum e verbo, even the two Greek particles $\mu \varepsilon \dot{\varepsilon} v \gamma \grave{\alpha} \rho$ (men gar) are rendered (quidem enim) - this does not seem to be proper Latin ${ }^{266}$ - whereas Bruni used only one (enim) which makes the sentence run smoother. The infinitives intellegere and facere which William had used following the Greek source Bruni replaced by the grammatically more idiomatic supine cognitu and factu which are emphasized by their position at the end of the respective clause. ${ }^{267}$ Bruni diverged from Aristotle only in so far as he changed the paratactic antithesis of the first sentence to a hypotactic structure. This has the effect that from the very beginning, the introductory conjunction cum (in concessive sense) prepares the reader to expect that the idea expressed in the first part will be contrasted by some alternative thought, by a different idea. This was not the case in the Aristotelian textactually in the first words Aristotle quotes almost verbally Plato ${ }^{268}$ who had not added the contrast of 'doing'. And by choosing the hypotactic structure Bruni pronounces a judgment on which of the two parts of the paratactic antithesis of the original he considers more important. These changes are very subtle, but nevertheless show a translator who thought about the meaning of the text and about how to convey it best. It is important to stress this because when Bruni wrote: dicere enim voti est, evenire autem

265 P. 295.6 f. ed. Susemihl.

266 TLL, vol. 5, part 2, col. 588-9 lists enim combined with iuncturae, conjunctions and particles like atqui, but there is no example for quidem enim.

267 S.M. Leumann - J.B. Hofmann - A. Szantyr, Lateinische Syntax und Stilistik, Munich 1965, p. $382 \mathrm{f}$.

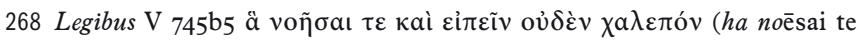
kai eipein ouden chalepon), cf. Schütrumpf, Aristoteles Politik VII/VIII, 2005, p. 440 n. on VII 12, 1331 b2o. 
fortunae, one is led to assume that he had William's translation, who had translated dicere quidem enim voti opus est, evenire autem fortunae, open on his desk. ${ }^{269}$ Bruni followed William's translation closely, except that he omitted two words, quidem and opus which again make it run smoother by freeing the Latin of unnecessary fillers. There was the view that Greek language lacked the conciseness of Latin, ${ }^{270}$ and Bruni wrote his translation as the Latin prose required it without incorporating idiosyncrasies of the Greek. This practice resulted in a leaner style whereas William had no consideration for the conventions of the Latin language. Bruni kept his independence from William and made changes that improved on the Latin grammar and succeeded in clarifying the logic of the argument and conveying the style of the original. ${ }^{271}$

Much more could be said on this subject. In my opinion Aristotle wrote at least his Politics and Nicomachean Ethics in an elegant manner which employs at the proper places discretely and with the best of judgment a varied style and does not tire the reader with the mindless use of rhetorical devices as is found in Isocrates. Was Aristotle's style too subtle for modern readers and even most scholars to appreciate its literary qualities? A noteworthy exception is Franz Dirlmeier who observed that according to

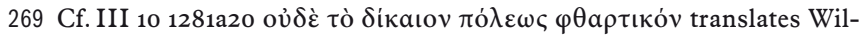
liam neque iustum civitatis corruptivum (p.190.3 ed. Susemihl), and Bruni (ed. Paris 1526, f. $46^{\mathrm{r}}$ ) takes over everything word by word, but adds only the auxiliary verb est (corruptivus is not used by Cic., but Tertullian, Jerome, Boethius, s. TLL vol. IV, col. 1067). Seigel 1968, p. 119 states the same for the translation of the Nicomachean Ethics: "He seems to have had the version of his predecessor before him while working on the Ethics," cf. the examples above p. $47 \mathrm{f}$.

270 E.g. expressed by Poggio Bracciolini in a letter to Francesco Accolti, effugi verbositatem qua Greci ut plurimum referti sunt, cited by Botley 2004, p. 48.

271 I would not agree with Botley 2004, p. 49, that "Bruni's translation does have a tendency to make Aristotle neater and clearer than he is in Greek," rather in Bruni's translation Aristotle is neater and clearer than in the clumsy literal translation of William. 
the quality of style, Politics was intended for publication. ${ }^{272}$ One cannot but agree with Bruni's argument that the stylistic quality of the source, its charm and splendor, need to be preserved in the translation. ${ }^{273}$ For Leonardo Bruni to use Cicero as his model for the style to be followed when translating Aristotle's Politics is clearly adequate, and the criticism leveled against Bruni's choice is based on a misunderstanding of the literary qualities of at least some of the works of Aristotle.

The union of philosophy and rhetoric which Cicero espoused $^{274}$ influenced Humanists ${ }^{275}$ and not the least L. Bruni. However, in his translations Bruni was not thinking of his role as an orator who could have a public influence, but of an artful translator who in his translation made Greek philosophy accessible to those who could read Latin. He used rhetoric not so much to make the translations more attractive but because the authors of these philosophical works, Plato and Aristotle, had already effectively employed rhetorical features when writing in a refined and polished style. If we enjoy the elegance of the Latin of Leonardo Bruni's translation of Aristotle, we might as well do this with a good conscience since he succeeded in reproducing the quality of Aristotle's prose.

272 F. Dirlmeier, Aristoteles. Werke in deutscher Übersetzung, vol. 7, Eudemische Ethik, ${ }^{4}$ 1984, p. 114: The Politics "war jedenfalls, wie die Stillage zeigt, für Publikation im modernen Sinne des Wortes gedacht." Cf. my paper cited above p. 71 n. 262.

273 De Interpretatione [12] p. 82: Cum enim in optimo quoque scriptore, et presertim in Platonis Aristotelisque libris, et doctrina rerum sit et scribendi ornatus, ille demum probatus erit interpres, qui utrumque servabit, cf. [14] p. 86 , cited above p. 68 n. 247.

274 Cf. De oratore III $17.64 ; 35.142 \mathrm{ff}$.

275 S. Seigel 1968. 


\section{APPENDIX}

Observations on the editions of Bruni's translation of Aristotle Pol. ed. Strasbourg 1469; Paris 1511; 1515; 1526; Iuntina Venice 1568

The Strasbourg edition of 1469, the "first printed edition of Aristotle" (Riley, s. above p. 59 n. 229), provides an inferior text, marred by inconsistent spelling and by omissions. The Iuntina, Venice 1568, often agrees with the ed. of 1469 .

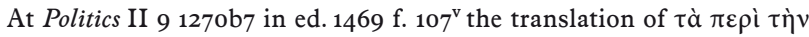
$\dot{\varepsilon} \varphi$ opcíav is que circa efforos constituta sint, whereas at b25 the spelling

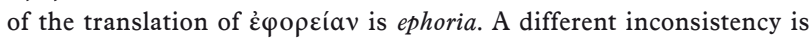
found $\mathrm{f} .102^{\mathrm{v}}$ (II 6 1265b39) quoniam efori ipsi ex plebe sumuntur. alii efforarum (obviously wrongly for efforatum) quidem tyannidem putant (s. above p. 47 n. 186).

At III 13 1284a17, f. $122^{\mathrm{r}}$ the Strasbourg ed. 1469 has ostratismus, against ostracismus ed. Paris 1511 f. $46^{\mathrm{r}} ; 1526$ f. $50^{\mathrm{r}}$; Iuntina 1568

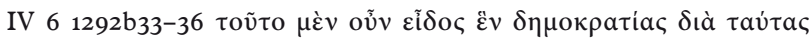

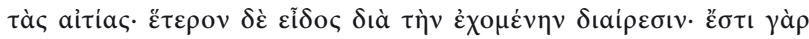

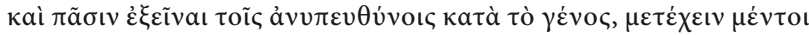

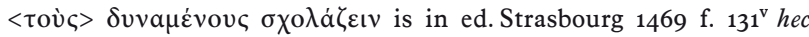
igitur est una species popularis gubernationis. Altera vero species est omnibus licere qui prohibiti non sint per genus ... (identical Iuntina $1568 \mathrm{f.} 57^{\mathrm{v}} / 58^{\mathrm{r}}$ ).

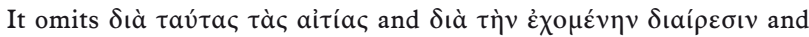
contracts therefore the syntactical structure. The edition Paris $1511 \mathrm{f}$. $57^{\mathrm{v}}$ hec igitur his de causis una est species popularis gubernationis. Altera vero species est ob adhibitam electionem. Nam omnibus licet republica participare qui prohibiti non sunt per genus ... (identical ed. Paris 1515 f. $50^{\mathrm{r}} ; 1526 \mathrm{f.} 62^{\mathrm{v}}$ ) exhibits the omitted words and restores the syntax.

Of these five printed editions, the ed. Paris 1515 is by far the worst:

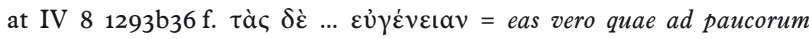
gubernationem vocare optimates, ex eo quia opulentioribus doctrina atque nobilitas is printed f. $51^{\mathrm{r}}$ twice

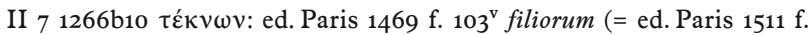
$23^{\mathrm{v}}$; 1526 f. $25^{\mathrm{v}}$; ed. 1568 f. $22^{\mathrm{v}}$ ), ed. Paris 1515 f. 21 filiarum

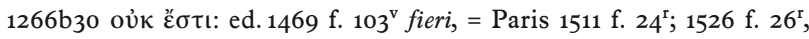
ed. Paris 1515 f. $18^{\mathrm{v}}$ feri

II $81268 b_{34} \dot{\varepsilon} \pi\left(\sigma \tau \eta \mu \tilde{\omega} v\right.$ ed. 1469 f. $106^{\mathrm{r}}$ with extreme contractions, ed. Paris 1511 f. $26^{\mathrm{v}}$ scientiis = ed. 1526 f. $28 \mathrm{v}$; Iuntina 1569 f. $25^{\mathrm{r}}$, ed. Paris 1515 f. $23^{\mathrm{v}}$ sententiis 


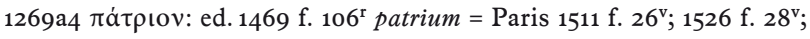
Iuntina 1568 f. $25^{\mathrm{r}}$, ed. Paris 1515 f. $26^{\mathrm{v}}$ partium

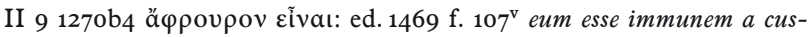
todia $=$ ed. Paris 1526 f. $31^{\mathrm{r}}$, ed. Paris 1515 f. $25^{\mathrm{r}}$ eum etsi immunem a custodia

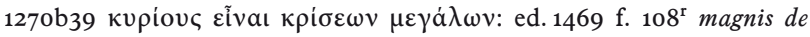
rebus decernendi potestatem $=$ Paris 1511 f. 25 ; ed. Paris 1526 f. $31^{\mathrm{r}}$; Iuntina $1568 \mathrm{f} .27^{\mathrm{v}}$, ed. Paris $1511 \mathrm{f.} 25^{\mathrm{v}}$ magnis de rebus discernendi potestatem

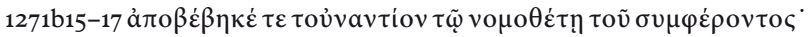

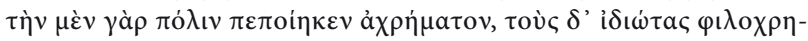
$\mu a \dot{\tau}$ ovs: ed. $1469108^{v}$ evenit ... publice inopiam privatim avaritiam inducere (= Iuntina $1568 \mathrm{f} .28^{\mathrm{v}}$ ). However, the other editions (Paris $1511 \mathrm{f}$. $29^{\text {r }} ; 1515$ f. $26^{\mathrm{r}} ; 1526$ f. $31^{\mathrm{v}}$ ) print evenit ... nam publice inopiam privatim avaritiam (ed. Paris 1515 f. $26^{\mathrm{r}}$ amicitiam) induxit. Here the version of 1469 is syntactically less close to the Greek since it makes the main

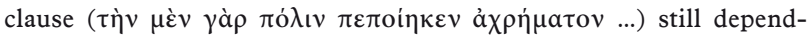
ent on the preceding ả $\pi \circ \beta \dot{\varepsilon} \beta \eta \kappa \dot{\varepsilon}$. It shows a preference for hypotaxis over parataxis (s. above p. 74) which the later editions seem to have removed in order to follow closer the Greek.

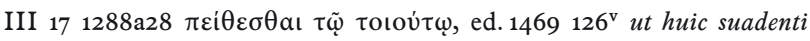
pareatur $=$ ed. Paris 1511 f. 51 $1^{\mathrm{v}}$; 1526 f. $56^{\mathrm{r}}$; Iuntina 1568 f. 51 $1^{\mathrm{r}}$, Paris 1515 f. $45^{\mathrm{r}}$ ut huic suadendi pareatur

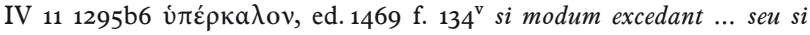
forma ... = Iuntina 1568 f. $61^{\mathrm{v}}$, ed. Paris 1515 f. $43^{\mathrm{v}}$ si modum excedant ... seu si fortuna ..., so already ed. Paris 1511 f. $61^{\mathrm{r}} ; 1526 \mathrm{f.} 67^{\mathrm{v}}$

\section{BIBLIOGRAPHY}

\section{EDITIONS}

\section{Aristotle}

Aristotelis Politicorum Libri octo cum vetusta translatione Guilelmi de Moerbeka, ed. F. Susemihl, Leipzig 1872

Aristotelis Ethica ad Nicomachum; Politica et Oeconomica Leonardo Aretino interprete, Strasbourg ap. Johann Mentelin, (before April 10) 1469 [Aristotelis] Politicorum libri octo ...; Economicorum duo; commentarji. Hecatonomiarum septem. Economiarum publ[icarum] unus. Explanationis Leonardi in Oeconomica duo. Apud Parisios ... ex officina Henrici Stephani, 1511, nonis Aprilis.

[Aristotelis] Politicorum libri Octo: Commentarii Economicorum Duo: Commentarii Hecatonomiarum Septem: Economiarũ publ. Vnus. Explanationis Leodardi [sic] in ceconomia Duo (p. II, Primus Politicorum Aristotelis 
ex traductione Leonardi ... elucidatore: Iacobo Fabro Stapulensi), François Regnault, Paris 1515

[Aristotelis] Politicorum libri Octo Cum Commentariis Jac. Fabri: Oeconomicorum Duo Cum Commentariis Jac. Fabri: Hecatonomiarum Septem: Economiarum publ. Vnus. Explanationis Leonardi in oconomia Duo. (p. 2, Primus Politicorum Aristotelis ex traductione Leonardi: recognitore et elucidatore: Iacobo Fabro Stapulensi), Paris, ex officina Simonis Colinaei, 1526 Aristotelis Stagiritae Politicorum siue De republica Libri octo Leonardo Aretino interprete cum d. Thomae Aqvinatis explanatione. Quibus antiqua (ut se habebat) eorundem adiecta est quae delitescebat, Politicorum interpretatio, quam d. Tho. olim exponendo secutus est, His accessere ipsius $d$. Thomae De Regimine Principum libri quatuor, ... in calce operis appositi leguntur Oeconomica etiam ex antiqua interpretation ... ne perirent, tanquam corollarium quoddam sunt addita Iul. Martiani Rotae labore ac diligentia ... cum indice ... Venetiis apud Iuntas, 1568

Aristoteles Latine, interpretibus variis, ed. Academia Regia Borussica, Berlin 1831, reprint ed. E. Keßler, Munich 1995, Humanistische Bibliothek. Reihe 2, Texte, Bd. 30 ("Einleitung" p. VII-XXXI).

Aristoteles Latinus, XXIX 1, Politica (Libri I-II.11). Translatio Prior Imperfecta Interprete Guillelmo De Moerbeka (?), ed. P. Michaud-Quantin, Bruges - Paris 1961

\section{Other authors}

Anicius Manlius Severinus Boethius In Isagogen Porphyrii Commenta, ed. G. Schepss - S. Brandt, CSEL vol. 48, Vienna 1906

Baron, H. Leonardo Bruni Aretino, Humanistisch-philosophische Schriften mit einer Chronologie seiner Werke und Briefe. Herausg. und erläutert, Leipzig - Berlin 1928

Birkenmajer, A. Vermischte Untersuchungen zur Geschichte der Mittelalterlichen Philosophie, Münster 1922

Bruni, Leonardo De interpretatione recta, a cura di P. Viti, Napoli 2004

Hieronymus Liber de optimo genere interpretandi (Epistula 57); Ein Kommentar, ed. G.J.M. Bartelink, Mnemosyne Suppl. 61, Leiden 1980

Luiso, F.P. Studi su l'epistolario di Leonardo Bruni, ed. L. Gualdo Rosa, Rome 1980

Oresme, Maistre Nicole Le Livre de politiques d'Aristote, ed. A.D. Menut, Transactions of the American Philosophical Society, New Series, vol. 6o, part 6, Philadelphia 1970

Petrarca, Francesco De ignorantia. Della mia ignoranza e di quella di molti altri, ed. E. Fenzi, Milan 1999

Salutati, Coluccio Epistolario, ed. F. Novati, vol. II, Rome 1893

Sancti Thomae De Aquino Opera Omnia. ed. L.-J. Bataillon - H.-F. Dondaine, Tomus XLVIII, Sententia libri politicorum, Tabula libri ethicorum, Rome 1971

Scoti, Joanni Opera quae supersunt omnia, ed. H.J. Floss, in: $P L$ vol.122, Paris 1853 


\section{SCHOLARSHIP ON TRANSLATIONS}

Adler, w. "Ad Verbum or ad sensum. The Christianization of a Latin translation formula in the fourth century", in: J.C. Reeves - J. Kampen (eds.), Pursuing the text. Studies in honor of Ben Zion Wacholder on the occasion of his seventieth birthday, Sheffield 1994, p. 321-348

Baron, H. Humanistic and Political Literature in Florence and Venice at the Beginning of the Quattrocento: Studies in Criticism and Chronology, New York ${ }^{2} 1968$

Berschin, W. Griechisch-lateinisches Mittelalter. Von Hieronymus zu Nikolaus von Kues, Bern 1980

Bertelloni, Fr. "Nähe und Distanz zu Aristoteles: Die neue Bedeutung von Civitas im politischen Denken zwischen Thomas von Aquin und Nikolaus von Kues," in: L. Cesalli et al. (eds.), University, council, city. Intellectual culture on the Rhine (1300-1550); acts of the XII ${ }^{\text {th }}$ International Colloquium of the Société Internationale pour l'Étude de la Philosophie Médiévale, Freiburg im Breisgau, 27-29 October 2004, Turnhout 2007, p. 323-347

Botley, P. Latin translation in the Renaissance. The theory and practice of Leonardo Bruni, Giannozzo Manetti and Desiderius Erasmus, Cambridge 2004 Brams, J. - Vanhamel, W. (eds.) Guillaume de Moerbeke. Recueil d'études à l'occasion du 7ooe anniversaire de sa mort (1286), Leuven 1989

Brams, J. "Guillaume de Moerbeke et Aristote", in: J. Brams - W. Vanhamel (eds.) 1989, p. 317-336

Brunner, 0. - Conze, W. - Koselleck, R. Geschichtliche Grundbegriffe. Historisches Lexikon zur politisch-sozialen Sprache in Deutschland, 9 vols., (Studienausgabe) Stuttgart 2004, in particular: W. Mager, art. "Republik", vol. 5, p. 549-651; F.-L. Knemeyer, art. "Polizei", vol. 5, p. 875-897; H. Mornhaupt, art. "Verfassung I", vol. 6, p. 831-862; D. Grimm, art. "Verfassung I", vol. 6, p. 863-899

Dod, B.G. "Aristoteles Latinus", CHLMPh 1982, 45-79

Du Cange, Ch. - Favre, L. Glossarium ad scriptores mediae et infimae Graecitatis, 2. ed. $1937 / 38$

Flüeler, Ch. Rezeption und Interpretation der aristotelischen Politica im späten Mittelalter, 2 parts, Bochumer Studien zur Philosophie vol. 19, Amsterdam 1992

Fögen, Th. Patrii sermonis egestas: Einstellungen lateinischer Autoren zu ihrer Muttersprache; ein Beitrag zum Sprachbewusstsein in der römischen Antike, München 2000

Grabmann, M. "Eine ungedruckte Verteidigungsschrift der scholastischen Übersetzung der Nikomachischen Ethik gegenüber dem Humanisten Lionardo Bruni," in: M. Grabmann, Mittelalterliches Geistesleben. Abhandlungen zur Geschichte der Scholastik und Mystik, Munich 1926, p. $440-448$ 
Grabmann, M. Guglielmo di Moerbeke O. p. il traduttore delle opere di Aristotele, Roma 1946

Gregorio, Fr. "Frankreich im 14. Jahrhundert: Nicole Oresme", in Horn et al. (eds.) 2008, p. 112-133

Griffiths, G. - Hankins, J. - Thompson, D. The Humanism of Leonardo Bruni. Selected texts, translations and introductions, Binghamton, New York 1987

Hamesse, J. - Fattori, M. (eds.) Rencontres de cultures dans la philosophie médiévale. Traductions et traducteurs de l'antiquité tardive au XIVe siècle, Actes du colloque international de Cassino 15-17 juin 1989, Louvainla-Neuve - Cassino 1990

Hankins, J. Plato in the Italian Renaissance, 2 vols., Columbia Studies in the Classical Tradition, vol. 17, Leiden-New York 1991 (= Hankins 1991) Hankins, J. Humanism and Platonism in the Italian Renaissance, vol. I (Humanism), in: Storia e Letteratura, Raccolta di Studi e Testi 215, Rome 2003 (= Hankins 2003), in particular: ch. 7: "Translation Practice in the Renaissance: The case of Leonardo Bruni", p. 177-192 (first published 1994); ch 8. "The Ethics Controversy", p.193-229 (first published 2001); ch. 9 "Manuel Chrysoloras and the Greek Studies of Leonardo Bruni". p. 243-271 (first published 2002)

Hankins, J. De Republica: "Civic Humanism in Renaissance Milan (and other Renaissance Signories)", in: M. Vegetti - P. Pissavino (eds.), I Decembrio e la tradizione della Repubblica di Platone tra Medioevo e umanesimo, Naples 2005, p. 484-508 (= Hankins 2005)

Hankins, J. "Humanism in the Vernacular: The Case of Leonardo Bruni", in: Ch.S. Celenza - K. Gouwens (eds.), Humanism and creativity in the Renaissance. Essays in honor of Ronald G. Witt, Leiden - Boston 2006, 11-29 (= Hankins 2006a)

Hankins, J. "The Popularization of Humanism in the fifteenth Century. The Writings of Leonardo Bruni in Latin and the Vernacular", in: L. Nauta (ed.), Language and cultural change. Aspects of the study and use of language in the Later Middle Ages and the Renaissance, Leuven 2006, 133-147 (= Hankins 2006b)

Hankins, J. "Greek Studies in Italy: From Petrarch to Bruni", in: M. Feo, V. Fera et al., Petrarch e il mondo Greco I, Atti del Convegno internazionale di studi Reggio Calabria 26-30 novembre 2001, Firenze 2007, 329-339 (= Hankins 2007)

Horn, Ch. - Neschke-Hentschke, A. (eds.) Politischer Aristotelismus. Die Rezeption der aristotelischen "Politik" von der Antike bis zum 19. Jahrhundert, Stuttgart 2008

Lambertini, R. "La diffusion della "Politica" e la definizione di un linguaggio politico Aristotelico", Quaderni Storici 102, 1999, 677-704

Marti, H. "Das Übersetzen Philosophischer Texte gegen Ende des 4. Jahrhunderts", in: J. Hamesse - M. Fattori (eds.) 1990, p. 23-45

Minio-Paluello, L. Opuscula. The Latin Aristotle, Amsterdam 1972 (collection of articles, in particular: "Guglielmo di Moerbeke traduttore della 
Poetica di Aristotle (1278)" (1947), p. 40-56; "Note sull' Aristotele Latino Medievale" (1950), p. 98-113; "Note sull' Aristotele Latino Medievale" (1952), p. 155-177; "Tre Note alla 'Monarchia'” (1955), p. 277-298)

Moraux, P. "Cicéron et les ouvrages scolaires d'Aristote", in: Atti del II Colloquium Tullianum Roma, 30 settembre - 2 ottobre 1974, Rome 1975, 81-96

Rubinstein, N. "The History of the Word politicus in Early Modern Europe," in A. Pagden (ed.), The Languages of Political Theory in EarlyModern Europe, Cambridge 1987, 41-56 (repr. in: N. Rubinstein, Studies in Italian history in the Middle Ages and the Renaissance, I Political Thought and the Language of Politics. Art and Politics, ed. G. Ciapelli, Rome 2004, 317-333) (= Rubinstein (1987) 2004)

Schmidt, J. "A raven with a halo: The translation of Aristotle's Politics", History of Political Thought 7 (1986), 295-319

Schmitt, Ch.B. Aristotle and the Renaissance, Cambridge Mass. 1983

Schneider, B. Die mittelalterlichen griechisch-lateinischen Übersetzungen der aristotelischen Rhetorik, Berlin 1971

Schütrumpf, E. Aristoteles. Werke in deutscher Übersetzung, Aristoteles Politik Buch I, vol. 1, Berlin - Darmstadt 1991; Buch II-III, vol. 2, 1991; Buch VII-VIII, vol. 4, 2005

Schütrumpf, E. Praxis und Lexis. Ausgewählte Schriften zur Philosophie von Handeln und Reden in der klassischen Antike, Palingenesia 95, Stuttgart 2009

Schwarz, W. "The Meaning of Fidus Interpres in Medieval Translation, Journal of Theological Studies 45, 1944, p. 73-78

Seigel, J.E. Rhetoric and philosophy in Renaissance humanism; the union of eloquence and wisdom, Petrarch to Valla, Princeton 1968

Steele, C. "Guillaume de Moerbeke et Saint Thomas", in: J. Brams - W. Vanhamel (eds.) 1989, p. 57-82

Vanhamel, W. "Biobibliography de Guillaume de Moerbeke", in: J. Brams - W. Vanhamel (eds.) 1989, 337-339

Verbeke, G. "Moerbeke, traducteur et interprète; un texte et une pensée“, in: J. Brams - W. Vanhamel (eds.), 1989, 1-21

Witt, Ronald G. 'In the footsteps of the ancients'. The origins of humanism from Lovato to Bruni, Leiden, Boston, Köln 2000

\section{L. BRUNI'S WORKS/ABBREVIATIONS}

De Interpretatione

Dialogus

Praefatio Oeconomicorum Aristotelis
De interpretatione recta, ed. P. Viti, Napoli 2004

Ad Petrum Paulum Histrum Dialogus, ed. E. Garin, Prosatori Latini del Quattrocento, Milan 1952, p. 44-99

Praefatio in Libros Oeconomicorum Aristotelis, ed. Baron 1928, p. 120-21 
Praemissio Ethicorum

Praemissio Politicorum

Vita Aristotelis

Arist.

Cic.

Hor.

Plat.

CHLMPh

CSEL

$P L$

$T L L$
Praemissio quaedam ad evidentiam novae translationis Ethicorum Aristotelis, ed. Baron 1928, p. 76-81

Praemissio quaedam ad evidentiam novae translationis Politicorum Aristotelis, ed. Baron 1928, p. 73-4 Vita Aristotelis, ed. Baron 1928, p. 41-49

Aristoteles/Aristotle

Cicero

Horatius

Plato

N. Kretzmann, A. Kenny, J. Pinborg，The Cambridge History of later medieval philosophy: from the rediscovery of Aristotle to the disintegration of scholasticism, 1100-1600, Cambridge 1982

Corpus Scriptorum Ecclesiasticorum Latinorum, 1866-

Patrologiae Cursus Completus sive bibliotheca universalis, ed. J.-P. Migne, 1844-1866

Thesaurus Linguae Latinae, Munich 1904-

\section{PICTURE CREDITS}

The four images on pages 60-63 are reproductions from the copy of Aristotelis Ethica ad Nicomachum; Politica et Oeconomica Leonardo Aretino interprete, Strasbourg ap. Johann Mentelin (before April 10) 1469, belonging to the holdings of the Beineke Library at Yale University. 
Bislang in der Morphomata-Lectures-Cologne-Reihe erschienen:

1 Ines Barner, Günter Blamberger (Hrsg.), Literator 2010. Dozentur für Weltliteratur. Daniel Kehlmann, 2012. ISBN 978-3-7705-5338-9.

2 Alan Shapiro, Re-Fashioning Anakreon in Classical Athens, 2012. ISBN 978-3-7705-5449-2.

3 Ines Barner, Günter Blamberger (Hrsg.), Literator 2011. Dozentur für Weltliteratur. Péter Esterházy, 2013. ISBN 978-3-7705-5445-4.

4 Marcello Barbanera, The Envy of Daedalus. Essay on the Artist as Murderer, 2013. ISBN 978-37705-5604-5.
5 Günter Blamberger, Figuring Death, Figuring Creativity: On the Power of Aesthetic Ideas, 2013. ISBN 9783-7705-5605-2.

6 Dietrich Boschung, Kairos as a Figuration of Time. A Case Study, 2013. ISBN 978-3-7705-5614-4.

7 Jan Söffner, Metaphern und Morphomata, 2014. ISBN 978-37705-5615-1.

9 Steffen Siegel, Ich ist zwei andere. Jeff Walls Diptychon aus Bildern und Texten, 2014. ISBN 978-37705-5664-9. 


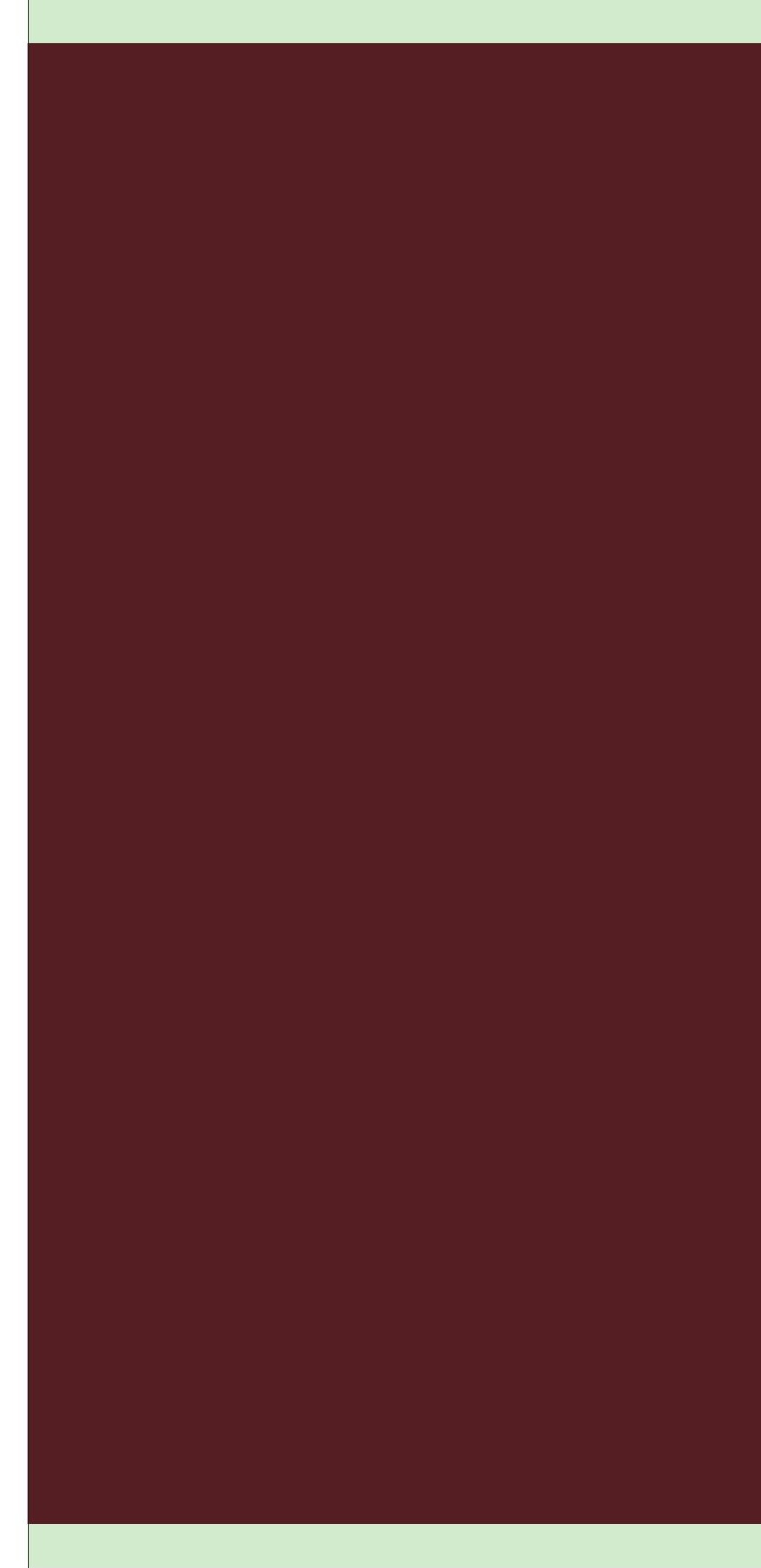




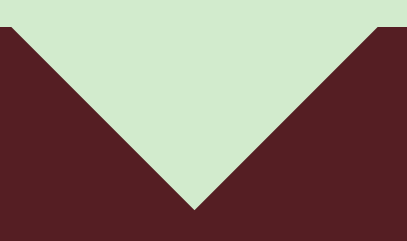

This study places the earliest translations of Aristotle's Politics into the larger context of approaches to translating Greek philosophical texts into Latin since Cicero. The option of rendering verbum pro verbo, word by word, was adopted by William of Moerbeke (c. 1215-1286) but rejected by Leonardo Bruni (1369-1444) whose polished style has been, undeservedly, criticized for ignoring the quality of Aristotle's prose. Nicole Oresme (c. 1323-1382) presented the first translation of Aristotle's Politics into a vernacular, French. All translators have contributed to the modern political vocabulary.
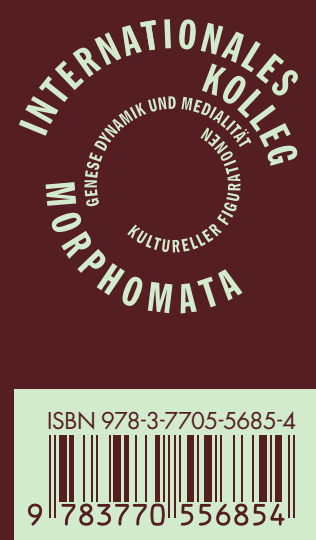

WILHELM FINK 